\title{
Noncoding RNAs in Extracellular Fluids as Cancer Biomarkers: The New Frontier of Liquid Biopsies
}

\author{
Barbara Pardini 1,2,3,*(D), Alexandru Anton Sabo ${ }^{4}$, Giovanni Birolo ${ }^{2,3}$ and \\ George Adrian Calin 1,5,6,*
}

1 Department of Experimental Therapeutics, The University of Texas MD Anderson Cancer Center, Houston, TX 77030, USA

2 Department of Medical Sciences, University of Turin, 10124 Turin, Italy

3 Unit of Molecular Epidemiology and Exposome, Italian Institute for Genomic Medicine (IIGM), 10126 Turin, Italy

4 Department of Pediatrics, Marie Curie Emergency Clinical Hospital for Children, 077120 Bucharest, Romania

5 Center for RNA Interference and Non-Coding RNAs, The University of Texas MD Anderson Cancer Center, Houston, TX 77030, USA

6 Department of Leukemia, The University of Texas MD Anderson Cancer Center, Houston, TX 77030, USA

* Correspondence: barbara.pardini@iigm.it (B.P.); gcalin@mdanderson.org (G.A.C.); Tel.: +1-713-792-5461 (G.A.C.)

Received: 5 July 2019; Accepted: 10 August 2019; Published: 14 August 2019

Abstract: The last two decades of cancer research have been devoted in two directions: (1) understanding the mechanism of carcinogenesis for an effective treatment, and (2) improving cancer prevention and screening for early detection of the disease. This last aspect has been developed, especially for certain types of cancers, thanks also to the introduction of new concepts such as liquid biopsies and precision medicine. In this context, there is a growing interest in the application of alternative and noninvasive methodologies to search for cancer biomarkers. The new frontiers of the research lead to a search for RNA molecules circulating in body fluids. Searching for biomarkers in extracellular body fluids represents a better option for patients because they are easier to access, less painful, and potentially more economical. Moreover, the possibility for these types of samples to be taken repeatedly, allows a better monitoring of the disease progression or treatment efficacy for a better intervention and dynamic treatment of the patient, which is the fundamental basis of personalized medicine. RNA molecules, freely circulating in body fluids or packed in microvesicles, have all the characteristics of the ideal biomarkers owing to their high stability under storage and handling conditions and being able to be sampled several times for monitoring. Moreover, as demonstrated for many cancers, their plasma/serum levels mirror those in the primary tumor. There are a large variety of RNA species noncoding for proteins that could be used as cancer biomarkers in liquid biopsies. Among them, the most studied are microRNAs, but recently the attention of the researcher has been also directed towards Piwi-interacting RNAs, circular RNAs, and other small noncoding RNAs. Another class of RNA species, the long noncoding RNAs, is larger than microRNAs and represents a very versatile and promising group of molecules which, apart from their use as biomarkers, have also a possible therapeutic role. In this review, we will give an overview of the most common noncoding RNA species detectable in extracellular fluids and will provide an update concerning the situation of the research on these molecules as cancer biomarkers.

Keywords: noncoding RNAs; body fluids; liquid biopsy; long noncoding RNAs; microRNAs; piRNAs 


\section{Introduction}

In oncology, a biomarker is defined as a measurable alteration in a sample that is associated with cancer condition or that could have a predictive or prognostic value. In the era of precision medicine, high sensitivity and specificity are essential characteristics for a good biomarker, especially if it is meant to be used for detecting early cancer stages [1]. Highly predictive biomarkers are not only useful for screening and for a better diagnosis, but mostly they could serve as a starting point to understand the biological pathways and regulatory mechanisms involved in the pathology and could serve as a potential target for drugs [2].

An effective management of cancer could be reached with effective cancer screening programs, an early diagnosis, an efficient classification of the prognosis, but also with a good plan for monitoring disease progression and efficacy of the therapy [3]. Besides the recent advances in the molecular biology, the histological examination of biopsy tissues remains the gold standard for the majority of cancer diagnoses. However, biopsies are unpleasant and risky for the patients, as well as expensive and time-consuming. In addition, they are difficult to perform and require a certain expertise of the pathologists [4]. Consequently, there is a large interest in the application of alternative methodologies to search for noninvasive cancer biomarkers. Noninvasive biomarkers, and in particular circulating nucleic acids, represent a better option for patients because they are easier to be sampled, less painful, and potentially more economical. When comparing solid with liquid biopsies, a series of other advantages of the latter must be mentioned. Firstly, liquid biopsies can be used in the early detection of cancer, before radiologic and imaging events have detected the presence of a tumor (which can be assessed by traditional biopsy). Secondly, especially when considering histologically heterogeneous tumors, liquid biopsies may better characterize the tumor as a whole, while classic biopsies, analyzing only specific fragments, might miss some of the molecular characteristics. Thirdly, the possibility with liquid biopsies of repeated sampling permits a better and more dynamic disease progression monitoring and modulation of treatment. Liquid biopsies can be potentially applied in tracking tumor clonal evolution over time, testing for tumor resistance mechanisms, assessing treatment response, and detecting minimal residual disease, elements which constitute the fundamental basis of personalized medicine. Lastly, in the patient follow-up, liquid biopsies can be used as a convenient tool in the early detection of recurrence (Figure 1) $[5,6]$.

Biomolecules such as proteins, DNA, and RNA are potentially optimal candidates as biomarkers, and can be isolated from several biological materials. In the last years, great attention has been dedicated to the detection of such biomarkers in body fluids [7]. Among these molecules of interest, RNA is most probably the best candidate. In fact, compared with protein biomarkers, RNA detection presents higher sensitivity and specificity, and the analyses are less expensive. On the other hand, compared with DNA, RNA biomarkers provide better dynamic insights of cell regulation and states. Moreover, some specific RNAs (such as circular RNAs (circRNAs) and microRNAs (miRNAs)) are stable in the majority of body fluids (Figure 1) [2].

However, not all of the aforementioned advantages of liquid biopsies are available for RNA-based analyses. For example, the tracking of clonal events through liquid biopsies is rather possible through circulating DNA (ctDNA) or circulating tumor cells (CTC), while cell-free RNA (cfRNA) cannot be used for this purpose [5]. Moreover, since these molecules are a reflection of biological processes throughout the body, other concurrent biological events (e.g., sepsis) are known to majorly influence the circulating RNA expression profiles [8] and may interfere with the oncologic theranostic process. Even so, under these circumstances, RNA-based analytics have non-neglectable advantages and therapeutic applications, which will be further described in this review. 


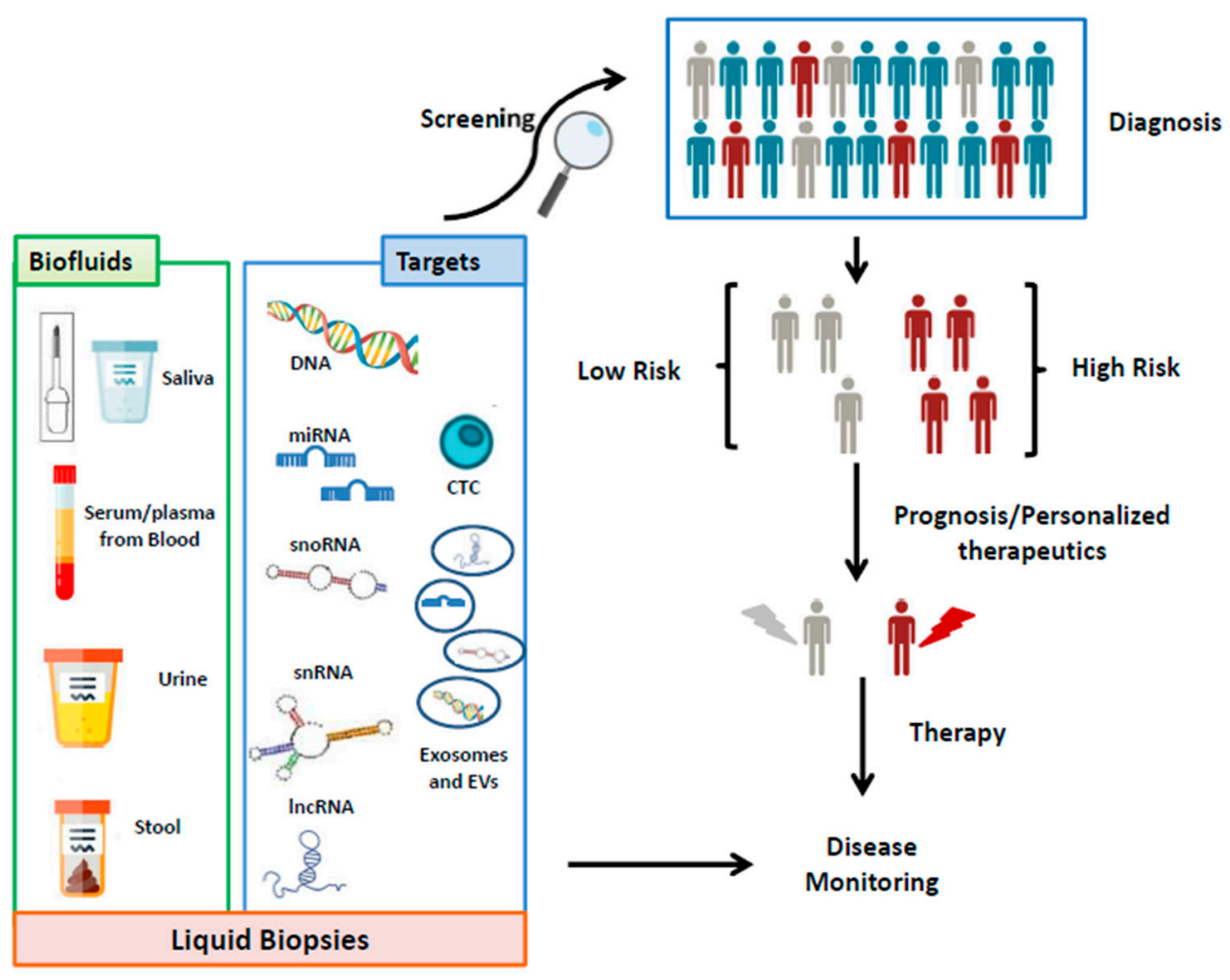

Figure 1. An effective management of cancer diagnosis screening by using body fluids and molecular biomarkers (CTC: circulating tumor cells; snoRNA: small nucleolar RNA; snRNA: small nuclear RNA; lncRNA: long noncoding RNA; EVs: extracellular vesicles).

Mammalian genomes are highly transcribed, and the majority of the transcripts do not code for proteins $[9,10]$. Once excluded messenger RNAs (mRNAs), the remainder of the transcriptome contains vast classes of noncoding RNAs (ncRNAs) that are functional elements not comprehensively studied yet. The cellular repertoire of ncRNAs includes: miRNAs, circRNAs, small housekeeping RNAs such as ribosomal (rRNAs) and transfer RNAs (tRNAs), and long noncoding RNAs (lncRNAs). miRNAs, the most studied small ncRNAs, account for less than $2 \%$ of the total ncRNAs [9]; much remains to be discovered for the remaining noncoding transcriptome [11].

The majority of ncRNAs have regulatory functions: they could be transcribed constantly together with coding RNAs, or they could be the results of environmental stimulation as a response to certain specific situations [12]. Interestingly, hypoxia has been shown to induce the transcription of genetic regions that are not transcribed in nonhypoxic settings, generating the hypoxia-induced noncoding ultraconserved transcripts, also called HINCUTs, which are implicated in the oncogenic process [13]. Most probably, not all the ncRNAs are functional; however, most of them, other than miRNAs could be essential for both physiological function and development, as well as playing a fundamental role in disease such as cancer $[10,14]$.

With the development and affirmation of next-generation sequencing (NGS) technology, the identification and quantification of various types of RNAs have become much easier and more powerful. For example, with NGS it has been possible to detect a large amount of new Piwi-interacting RNAs (piRNAs) or discover new genomic elements such as Pyknons ("peak-non-s"), a class of short DNA sequence motifs that can be also contained in lncRNAs [15]. NGS enables, in fact, not only to detect novel transcripts but also to detect with great accuracy nucleic acids in samples like plasma, urine, and other body fluids and extracellular matrices in which the amount of such species is very low [16]. These technological advances have revolutionized ncRNAs discovery.

In the present review, we focused on the emerging potential of ncRNAs as cancer biomarkers in liquid biopsies. 


\section{The Circulating Transcriptome}

cfRNAs were discovered in 1999 with the description of Epstein-Barr virus RNA in the plasma of nasopharyngeal carcinoma patients [17]. This was followed by the discovery of free-circulating mRNAs in melanoma patients' serum [18]. With few exceptions, the large majority of cfRNAs are degraded by RNAse activity in blood $[19,20]$. However, a great improvement in the field has been reached with the discovery of cell-free miRNAs in the blood of cancer patients [21,22]. In contrast to long molecules of RNA species (i.e., mRNA), circulating miRNAs are highly stable: they are resistant to degradation at room temperature for up to 4 days and in deleterious conditions such as boiling, stable after multiple freeze-thaw cycles, and insensitive to high or low $\mathrm{pH}$ [22]. The high potentialities of miRNAs as cancer biomarkers have generated an increased interest in these molecules. Finally, the advent of more powerful and available NGS technologies (RNA-seq) has enlarged the interest also to other ncRNAs that could be present in body fluids (for example lncRNAs and other small ncRNAs), either as free-circulating molecules or packed into microvesicles such as exosomes [23] (Figure 1).

Considering technological advances from recent years, heterogeneity in pre-analytical and analytical steps is still present across published studies. This heterogeneity largely affects the reported results. For example, there are several available techniques for exosome purification (ultracentrifugation, separation by specific solutions like Exoquick, etc.), and isolating specifically tumor-derived exosomes would be desirable, although practical and technical hindrances still exist. Likewise, nucleic acids isolation through different commercially available kits, quantification methods, and a number of methodologies for expression levels assessment (ranging from microarray and RT-qPCR to NGS) all account for heterogeneity and pose technological challenges to researchers. For more information on technical aspect, pitfalls, and limitations please refer to Anfossi et al. [14]. Also, for an up-to-date analysis on the extracellular vesicles please check Xu et al. [24].

Besides the increased application to body fluids analyses of RNA-seq in the last years, most available publications are focused on miRNAs, while the research on cell-free ncRNAs other than miRNAs is a recent field of study. Huang and colleagues presented one of the first works on the whole circulating transcriptome, performed by RNA-seq on plasma extracellular vesicles from healthy subjects [25] and cancer patients [26]. The majority of the obtained reads were from miRNAs (about $40 \%$ ), but there was also a good representation of rRNAs, lncRNAs, and piRNAs. The presence of a multitude of ncRNAs species in various body fluids able to characterize them, has been observed in various studies [27-30].

Few studies investigated the cell-free whole circulating transcriptome in search of cancer biomarkers [31-34] and, in such cases, the proportion of ncRNA species was variable depending on the body fluids of origin but also on the nucleic acids detection method. The origin of cfRNAs is still an issue for the scientific community. Extracellular RNAs can be released in a passive way as a derivate of the cell activity and death [35], or can be actively secreted from cells, either associated with membrane-derived extracellular vesicles (such as exosomes and microparticles) [22,36] or alternatively conjugated with proteins (lipoproteins, Argonaute 1 and 2 etc.) [37].

Exosomes secreted from a malignant cell often reflect the molecular composition of the cell of origin [38]. The loading of molecules into the exosomes is a selective process not completely clarified yet. In the specific case of cancer and tumor-reactive immune cells, exosomes and other microvesicles are released into the bloodstream or other body fluids to transfer specific paracrine or endocrine messages [23], to regulate and induce specific tumor functions such as growth, migration, anti-cancer drug resistance, and cell cycle control [39]. Yu et al. found that exosomes from highly metastatic pancreatic cancer cells contained differentially expressed proteins involved in exosome-mediated intercellular communication [40]. Tumor-derived exosomes carry specific molecular signatures that characterize different stages of tumor progression, with an interesting perspective to use these molecules as diagnostic and prognostic markers [41] or even as therapeutic targets [42-44]. 


\section{MiRNAs in Biological Fluids}

miRNAs are endogenous small ncRNA molecules of 19-22 nucleotides of length that post-transcriptionally modulate the expression of protein-coding genes through binding to specific sequences on target genes [45]. miRNAs pair with their target mRNAs with imperfect binding, therefore they can regulate hundreds of transcripts, at least potentially [46]. miRNAs have a tissue-specific pattern of expression and often are expressed in an aberrant way in many diseases, including cancer [47-50]. Interestingly, it has been shown in murine models that miRNA genes are located in genetic loci associated with cancer susceptibility [51]. miRNAs have been detected in various extracellular body fluids such as plasma and serum [37,52,53], cerebrospinal fluid (CSF) [54], saliva [55], breast milk [56], urine [57], and ovarian follicular fluid [58].

The extracellular miRNAs can be delivered to target cells as free-circulating molecules (often associated with proteins, especially Argonaute 2) or loaded into vesicles such as exosomes, microvesicles, and apoptotic bodies and behave with a hormone-like mechanism for intercellular communication, acting as autocrine, paracrine, and/or endocrine regulators to modulate cellular activities $[23,59,60]$. In fact, they can regulate the activity of host cells, but, more interestingly, precursors and mature miRNAs in microvesicles could also be secreted and transferred to recipient cells where they are functionally active [61-63]. Therefore, in the last years, hormone-like activities of long-distance circulating miRNAs have been recognized $[23,64]$.

In Table 1, we report a selection of the most recent studies reporting miRNAs circulating in body fluids that have been detected as possible cancer biomarkers. The list may not be complete, as a large number of papers published in the last years investigated the role of miRNAs as biomarkers for specific cancer diagnosis. The studies listed here are the most recent available, but we invite readers to search for more details about specific cancers in more cancer-type-focused reviews [65].

The majority of the studies available were investigating serum, plasma, or vesicles derived from these specimens [25,66-92], but there are also some examples of miRNAs found altered in urine [57,66,93-96], saliva [66,97], cerebrospinal fluid [91], and stool [66] (Table 1). One of the first described miRNA, and one of the most recurrently detected as a cancer biomarker is miR-21, implicated in a wide range of cancers ranging from the digestive to respiratory tract, hematological, gynecological, and brain malignancies. miR-21 is an oncomiR implicated in several signaling pathways, its upregulation resulting in inactivation of several tumor suppressors [98].

Being very abundant in serum and plasma samples, the let-7 family has been detected by multiple researchers in several types of cancers, such as hepatocellular cancer (HCC) [66], gastric [76], colorectal [66], but also urologic - urinary bladder [57], prostate [25,84-86,89,95,99], pulmonary [66], breast [90], and ovary [66,92,100]. Likewise, miR-155 has been also reported as dysregulated in serum/plasma samples in gastroenterology malignancies (esophageal [66], pancreatic [73], and colorectal [80] cancers), pulmonary [67], breast [101], ovary [102], and additionally, hematologic malignancies (acute leukemia [66] and lymphoma [66]). Another miRNA detected in serum and plasma exosomes and found to be dysregulated in several cancers is miR-144 [25,86,87].

Many miRNAs have been reported to be dysregulated and involved in several types of cancers, which makes sense when thinking of their general action as either oncogenes or tumor suppressors. Still, in the quest of identifying precise disease-specific biomarkers, the question of miRNA specificity has to be addressed. We compared those miRNAs reported as biomarkers in body fluids (Table 1) with the miRcancer database (https://mircancer.ecu.edu) [103-105], that lists miRNAs dysregulated in cancer, mainly from tumor tissue samples. We reported which miRNAs were found to be dysregulated either in body fluids, tumor tissues, or both (B, T, and BT, respectively) in Supplementary Table S1A-C. The cross-matched table was generated in order to have an overview of the miRNA "specificity" in certain tumors or specimens. Few of the reported miRNAs were really specific to one single type of cancer. miR-21-5p, a known oncomiR, was the one implicated in the largest number (19) of tumors in both body fluids and tissues; miR-101-3p was the most frequently altered in tissues, only within 20 types of cancer, and miR-197-3p was the most implicated in body fluids, only within 5 cancer 
types. We found only a couple of miRNAs that were specific to a single cancer category (Table S1A,B). As an example, miR-127-3p was associated only with gynaecologic cancers (breast, ovarian and cervical) in body fluids (but also to other cancers in tissues). On the other hand, miR-1285-3p was associated only to urologic cancers: prostatic cancer in body fluids, and renal cell carcinoma in tissues (Table 1 and Table S1A-C). This observation is explainable by the fact that miRNAs are implicated in general oncogenic pathways (e.g., miR-21 and let-7 are implicated in the Ras and NF-kB pathways [106]), and to some extent also in more specific pathways (e.g., the implication of miR-155 in the Diffuse large B-cell lymphoma (DLBCL) genesis through interaction with SHIP1 and C/EBP $\beta$ pathways $[107,108]$ ).

On the other hand, some miRNAs were specific to just one cancer type. For instance, 55 individual miRNAs were dysregulated only in one type of cancer in both body fluids and tissues, 214 in tissues and 239 in body fluids (Table S1B).

The highest number of miRNAs dysregulated in both body fluids and tumor tissues were in breast cancer, HCC, and chronic leukemia with respectively 51, 299, and 85 miRNAs in common (Table S1A,C). Some miRNAs resulted altered in a large number of cancers. As an example, miR-21-5p was a good biomarker in tissues and body fluids for leukemia, lymphoma, pancreatic, gastric, esophageal, colorectal, renal, breast, prostate, and ovarian cancers, but also for non-small-cell lung cancer (NSCLC) and glioma. miR-17-5p, another known oncomiR, was altered in leukemia, lymphoma, esophageal, liver, pancreatic, gastric, colorectal, and breast cancer, as well as glioma and NSCLC (Table S1B,C).

Under these circumstances, understanding the implication of miRNAs in specific pathways and finding the most sensitive and specific ones is still challenging. Many studies have not focused on single miRNAs, but proposed specific cancer diagnostic panels and diagnostic trees with greater specificity and sensitivity compared with single miRNA. For example, we proposed a 3-miRNAs panel for bladder cancer diagnosis [57], while regarding brain cancers, several researchers described multiple miRNA panels useful in the glioma diagnosis [109-111], as recently reported by us [91]. This trend also complies to the pragmatic needs of clinical medicine, where accurate, standardized tools are needed, not only for the diagnostic, but also for the prognostic and therapeutic management.

The number of studies covering miRNAs implicated in all cancers and detectable as biomarkers in body fluids is extremely high, also considering the increase of interest of researchers on these molecules in the last years. For a complete in-depth review investigating all the single studies of free-circulating and exosome miRNAs as cancer biomarkers, please refer to $[23,66,67,100,112-122]$. For example, the role of exosomal miRNAs in body fluids for prostate cancer diagnosis has been investigated by many groups and recently reviewed by Valentino et al. [123] and Fabris et al. [124]. Likewise, the measurement of miRNAs derived from blood and cerebrospinal fluid in brain tumors has been recently covered by Petrescu et al. [91]. For an extensive review of miRNAs involved in gastric cancer refer to Bhat et al. [76]; regarding ovarian cancer, refer to the work of Giannopoulou et al. [92], while several reviews are available on breast cancer, focusing on the complex milieu of miRNAs in liquid biopsies [90,125-127]. Regarding haematologic malignancies, a recent review by Drokow et al. [128] summarized the main miRNAs with potential use as diagnostic biomarkers. Concerning the general implication of miRNAs in acute myeloid leukemia (AML), please refer to Liu et al. [129]. Likewise, the complex implications of miRNAs in chronic lymphocytic leukemia (CLL) are reviewed by Mirzaei et al. [130] and Ciccone et al. [131], while for chronic myeloid leukemia (CML), see Litwińska et al. [132]. Finally, for more information about pediatric hematologic malignancies, please refer to Carvahlo de Oliveira et al. [133]. 
Table 1. Small noncoding RNAs (microRNAs, piwi-interacting RNAs, and sn/snoRNAs) with possible application as diagnostic biomarkers in body fluids.

\begin{tabular}{|c|c|c|c|c|}
\hline Cat. & Cancer Type & miRNA & piRNA & sn/snoRNA \\
\hline \multirow{5}{*}{ Digestive } & Oral cancer & $\begin{array}{l}\text { miR-125a, miR-200a (SA) [97] } \\
\text { miR-16, miR-29a (S) [66] } \\
\text { miR-125b (P) [66] }\end{array}$ & & \\
\hline & $\begin{array}{l}\text { Nasopharyngeal } \\
\text { cancer }\end{array}$ & $\begin{array}{c}\text { miR-548q, miR-630, miR940 (P) [134] } \\
\text { miR-16, miR-21, miR-24, miR-155, miR-378 (P) [135], miR-548q, } \\
\text { miR-483-5p (P) [136], miR-24 (P) [137] } \\
\text { miR-17, miR-20a, miR-29c, miR-223 (S) [138], } \\
\text { miR-486-5p, miR-45, miR-100 (S) [139] } \\
\text { miR-188-5p, miR-1908, miR-3196, miR-3935, miR-4284, miR-4433-5p, miR-4665-3p, } \\
\text { miR-513b (B) [140] } \\
\text { miR-31-5p (B) [141] } \\
\text { miR-34c-3p, miR-18a-5p (TEP) [142] }\end{array}$ & & \\
\hline & Esophageal cancer & $\begin{array}{c}\text { miR-16, miR-17, miR-20a, miR-30a, miR-155, miR-375 (P) [66] } \\
\text { miR-10, miR-18a (S) [66] } \\
\text { miR-21, miR-1246 (SE) [67] } \\
\text { miR-30a (SE) [67] }\end{array}$ & & \\
\hline & $\begin{array}{l}\text { Hepatocellular } \\
\text { carcinoma }\end{array}$ & $\begin{array}{l}\text { let-7b, let-7f, miR-16, miR-17, miR-30e, miR-125a, miR-221, miR-375 (S) [66] } \\
\text { miR-18a, miR-221, miR-222, miR-224 (SE) [68] } \\
\text { miR-106b (P, SE) [66] }\end{array}$ & & \\
\hline & Cholangiocarcinoma & $\begin{array}{c}\text { miR-29, miR-122, miR-155, miR-192 (S) [143] } \\
\text { miR-483-5p, miR-194 (S) [144] } \\
\text { miR-150-5p (S) [145] } \\
\text { miR-26a (S) [146] } \\
\text { miR-106a (S) [147] } \\
\text { miR-1281, miR-126, miR-26a, miR-30b, miR-122 (S) [148] } \\
\text { miR-21, miR-221 (P) [149] } \\
\text { miR-150 [150] (P) } \\
\text { miR-412, miR-640, miR-1537, miR-3189 (BI) [148] } \\
\text { miR-9, miR-145* (BI) [151] } \\
\text { Pancreato-biliary cancers vs. Healthy Controls: } \\
\text { miR-6075, miR-4294^, miR-6880-5p, miR-6799-5p, miR-125a-3p, miR-4530^, } \\
\text { miR-6836-3p, miR-4476^ (S) [152] } \\
\wedge \text { = reported, but no sufficient available data (www.miRbase.org) }\end{array}$ & & RNU2-1f (BI) [153] \\
\hline
\end{tabular}


Table 1. Cont

\begin{tabular}{|c|c|c|c|c|}
\hline \multirow[t]{5}{*}{ Cat. } & Cancer Type & miRNA & piRNA & sn/snoRNA \\
\hline & $\begin{array}{l}\text { Gallbladder } \\
\text { carcinoma }\end{array}$ & let-7a, miR-21, miR-187, miR-143, miR-202, and miR-335 (P) [154] & & \\
\hline & Pancreatic cancer & $\begin{array}{c}\text { miR-486-5p, miR-938 (P) [69] } \\
\text { miR-486-5p, miR-126-3p, miR-106b-3p (P) [70] } \\
\text { miR-223 (P) [71] } \\
\text { miR-182 (P) [72] } \\
\text { miR-10b, miR-30c, miR-106b, miR-155, miR-212 (P) [73] } \\
\text { miR-1290 (S) [74] } \\
\text { miR-192 (S) [75] } \\
\text { miR-21, miR-17-5p (S) [67] } \\
\text { miR-210 (P, U) [66] }\end{array}$ & $\begin{array}{c}\text { piR-016658, } \\
\text { piR-001311 (PV) [26] }\end{array}$ & $\begin{array}{c}\text { SNORA74A, } \\
\text { SNORA25 (S/SE) [155] } \\
\text { RNU2-1f (P/S) [156] }\end{array}$ \\
\hline & Gastric cancer & $\begin{array}{c}\text { miR-199-3p, miR-20a, miR-106b, miR-221, miR-486, miR-451, miR-17-5p, miR-106a, } \\
\text { miR-106b, miR-21, let-7a, miR-195-5p (P) [76] } \\
\text { miR-21, miR-221, miR-376c, miR-744, miR-378, miR-195-5p, let-7a, miR-196a, } \\
\text { miR-451, miR-486 (S) [76] } \\
\text { let-7c, let-7i, let-7f, miR-17, miR-17, miR-106b (S) [66] } \\
\text { miR-200c (P, S), miR-16 (P, S) [66] } \\
\text { let-7a, miR-18a, miR-19b, miR-106a, miR-17, miR-106a/b, miR-106b (P) [66] }\end{array}$ & $\begin{array}{l}\text { piR-823, piR-651 } \\
\text { (B) [157] }\end{array}$ & \\
\hline & $\begin{array}{c}\text { Colorectal cancer } \\
\text { (CRC) }\end{array}$ & $\begin{array}{c}\text { miR-25-3p [77] (SE) } \\
\text { miR-27a, miR-130a (SE) [78] } \\
\text { miR-17, miR-18a, miR-18b, miR-19a, miR-19b, miR-20a, miR-20b, miR-106a } \\
\text { miR-21, miR-23a, miR-224, miR-92a, miR-155 (SE) [80] } \\
\text { miR-196b-5p (SE) [81] } \\
\text { miR-217 [158] (SE) } \\
\text { miR-182-5p, miR-149, miR-96-5p (SE) [82] } \\
\text { miR-19a, miR-29b, miR-29c, miR-125b, miR-155 (S) [66] } \\
\text { miR-92a, miR-17/-92, miR-200c, miR-141, miR-375 (P) [66] } \\
\text { let-7f, miR-18a, miR-20a (F) [66] } \\
\text { miR-29a (P, S) [66] } \\
\text { miR-221 (P, F) [66] } \\
\text { miR-106a (F, P) [66] } \\
\text { let-7a (SE, P) [66] }\end{array}$ & $\begin{array}{l}\text { piR-019825 (PV) [26] } \\
\text { piR-5937; piR-28876 } \\
\text { (S) [159] } \\
\text { piR-001311, } \\
\text { piR-004153, } \\
\text { piR-017723, } \\
\text { piR-017724, } \\
\text { piR-020365 (S) [160] }\end{array}$ & RNU2-1f (P/S) [156] \\
\hline
\end{tabular}


Table 1. Cont

\begin{tabular}{|c|c|c|c|c|}
\hline Cat. & Cancer Type & miRNA & piRNA & sn/snoRNA \\
\hline \multirow{18}{*}{ Respiratory } & \multirow{10}{*}{ NSCLC } & miR-193b, miR-301, miR-141, miR-200b (S) [83] & & \multirow{10}{*}{$\begin{array}{c}\text { snoRD33, snoRD66, } \\
\text { snoRD76 (P) [161] } \\
\text { snoRD33; snoRD66; } \\
\text { snoRD42; snoRD78 } \\
\text { (SP) [162] RNU2-1f (S) } \\
{[163,164]}\end{array}$} \\
\hline & & $\begin{array}{l}\text { miR-17-3p, miR-21, miR-106a, miR-146, miR-155, miR-191, miR-192, miR-203, } \\
\text { miR-205, miR-210, miR-212, miR-214 (P) [67] }\end{array}$ & & \\
\hline & & $\begin{array}{l}\text { miR-34a (B); let-7i, miR-10, miR-19a, miR-19b, miR-29c, miR-30c, miR-34c, } \\
\text { miR-125a, miR-125b, miR-200c, miR-141, miR-429 (S); let-7a/b (P) [66] }\end{array}$ & & \\
\hline & & $\operatorname{miR}-20 a(P)[66]$ & & \\
\hline & & miR-30a (P) [66] & & \\
\hline & & miR-375 (P) [66] & & \\
\hline & & let-7a/b (S/P) [66] & & \\
\hline & & let-7f (PV) [66] & & \\
\hline & & miR-125b (S, P) [66] & & \\
\hline & & miR-155 (S, S/P) [66] & & \\
\hline & & miR-21, miR-155, miR-221 (P) [165] & & \\
\hline & & miR-155 (P) [166] & & \\
\hline & & miR-331-3p, miR-603, miR-1303, miR-660-5p, 212-3p (P) [167] & & \\
\hline & & miR-31, miR-141, miR-149a, miR-182, let-7a, miR-4853p, miR-122, miR-33, & & \\
\hline & Laryngeal cancer & miR-145, miR-223, miR-133a (S) [168] & & \\
\hline & & let-7 (S) [169] & & \\
\hline & & miRNA-378 (S) [170] & & \\
\hline & & $\operatorname{miR}-221(\mathrm{~S})[171]$ & & \\
\hline \multirow{7}{*}{ Urologic } & & miR-210 (S) [66] & \multirow{2}{*}{ piR-823 (S, U) [172] } & \\
\hline & Renal cell carcinoma & miR-221 (P) [66] & & \\
\hline & \multirow{5}{*}{ Bladder cancer } & miR-375 (UE) [93] & & \\
\hline & & miR-21-5p (UE) [94] & & \\
\hline & & miR-30a-5p, let-7c-5p and miR-486-5p (U) [57] & & \\
\hline & & miR-19a (P); miR-106b (U); miR-210 (S, U) [66] & & \\
\hline & & miR-324-5p, miR-4738-3p (together with miR-497-HG and RCAN1 FOSB mRNA) & & \\
\hline
\end{tabular}


Table 1. Cont.

\begin{tabular}{|c|c|c|c|c|}
\hline Cat. & Cancer Type & miRNA & piRNA & sn/snoRNA \\
\hline & Prostatic cancer & $\begin{array}{r}\text { let-7i, miR-16, miR-24, miR-26a, miR-26b, miR-34b, miR-92b, miR-93, miR-103, } \\
\text { miR-106a, miR-141, miR-195, miR-197, miR-223, miR-298, miR-328, miR-346, } \\
\text { miR-375, miR-1290 (S) [84,85] } \\
\text { let-7e, let-7c, miR-20a, miR-21, miR-30c, miR-130b, miR-145, miR-1811a-2 *, } \\
\text { miR-221, miR-301a, miR-326, miR-331-3p, miR-432, miR-574-3p, miR-622, miR-625 } \\
\text { *, miR-1285, miR-2110, miR-141, miR-1290 (PE) [25,86,99] } \\
\text { miR-107, miR-574-3p, miR-141-5p, miR-21-5p, miR-34a, miR-483-5p (PE) [87] } \\
\text { miR-375, miR-21, let-7c (UE) [95] } \\
\text { miR-196a-5p, miR-501-3p (UE) [96] } \\
\text { miR-103a-3p, let-7a-5p (P) [89] } \\
\text { let-7a (B) [66] } \\
\text { miR-20a (P) [66] } \\
\text { miR-30a (P) [66] } \\
\text { miR-30c (P) [66] } \\
\text { miR-375 (P) [66] } \\
\text { miR-34b, miR-16 (S) [66] } \\
\text { miR-141 (S, PV, SE) [66] }\end{array}$ & $\begin{array}{c}\text { piR-016658, } \\
\text { piR-020496 (PV) [26] }\end{array}$ & \\
\hline Gynaecologic & Breast cancer & $\begin{array}{l}\text { miR-195, let-7, miR-155, miR-138 (B); miR-214, miR-15a, miR-18a, miR-107, } \\
\text { miR-425, miR-133a, miR-139-5p, miR-143, miR-145, miR-365, miR-484, miR-1246, } \\
\text { miR-1307-3p, miR-6861-5p, miR-4634, miR-6875-5p, miR-155, miR-19a, miR-181b, } \\
\text { miR-24, miR-1, miR-92a, miR-133a, miR-133b, let-7c, miR-182, miR-155, miR-21, } \\
\text { miR-126, miR-155, miR-199a, miR-335, miR-201, let-7b, miR-4270, miR-1225-5p, } \\
\text { miR-188-5p, miR-1202, miR-148b-3p, miR-652-3p, miR-10b-5p, miR-18b, miR-103, } \\
\text { miR-107, miR-652, miR-10b, miR-34a, miR-155, miR-29b-2, miR-155, miR-197, } \\
\text { miR-205, miR-92a, miR-21, miR-21-5p, miR-375, miR-205-5p, miR-194-5p, } \\
\text { miR-382-5p, miR-376c-3p, miR-411-5p, miR-34a, miR-93, miR-373, miR-17, } \\
\text { miR-155, miR-125b, miR-122, miR-375, miR-155 (S); miR-127-3p, miR-376a, } \\
\text { miR-148b, miR-409-3p, miR-652, miR-801, miR-148b, miR-133a, miR-409-3p, } \\
\text { miR-505-5p, miR-125b-5p, miR-21-5p, miR-96-5p, miR-4281, miR-1207-5p, } \\
\text { miR-642b-3p, miR-1290, miR-3141, miR-10b, miR-373 (P)[90] } \\
\text { miR-101, miR-372, miR-373 (SE) [67] } \\
\text { miR-10, miR-16, miR-18a, miR-19a, miR-29a, miR-34a, miR-34b/c, miR-125a, } \\
\text { miR-375 (S) [66] } \\
\text { miR-106b, miR-125b (P) [66] } \\
\text { miR-34a (B) [66] } \\
\text { miR-155 (S, S/P) [66] }\end{array}$ & & RNU6 (S) [174] \\
\hline
\end{tabular}


Table 1. Cont

\begin{tabular}{|c|c|c|c|c|}
\hline Cat. & Cancer Type & miRNA & piRNA & sn/snoRNA \\
\hline & Ovarian cancer & $\begin{array}{c}\text { miR-214, miR-140, miR-147, miR-135b, miR-205, miR-150, miR-149, miR-370, } \\
\text { miR-206, miR-197, miR-634, miR-485-5p, miR-612, miR-608, miR-202, miR-373, } \\
\text { miR-324-3p, miR-103, miR-593, miR-574, miR-483, miR-527, miR-603, miR-649, } \\
\text { miR-18a, miR-595, miR-193b, miR-642, miR-557, miR-801, let-7e (SE) [100] } \\
\text { miR-193a-5p, miR-21, miR-375, miR-210, miR-150-5p, miR-181-5p, miR-142-3p, } \\
\text { miR-26a-5p, let-7d-5p, miR-374a-5p, miR-766-3p, miR-200a-3p, miR-130b-3p, } \\
\text { miR-328-3p, miR-1246, miR-595, miR-2278, miR-376a, miR-125b, miR-199a, miR-7, } \\
\text { miR-429, miR-25, miR-93, miR-200a, miR-200b, miR-200c, miR-145, miR-200c, } \\
\text { miR-141, let-7i-5p, miR-122, miR-152-5p, miR-25-3p, miR-22, miR-93, miR-451, } \\
\text { miR-106b, miR-21, miR-92, miR-221 (S) [92] } \\
\text { miR-373, miR-200a, miR-200b, miR-200c, miR-21, miR-92, miR-155, miR-127, } \\
\text { miR-93, miR-99b, miR-126, miR-29a, miR-21, miR-141, miR-203, miR-205, miR-214 } \\
\text { (SE) [92] } \\
\text { miR-148a, miR-200b, miR-26a, miR-625-3p, miR-720, miR-1274a, miR-19b, } \\
\text { miR-223, miR-16, miR-150, miR-20a, miR-126, miR-1290, miR-205, let-7f, miR-16, } \\
\text { miR-21, miR-191, miR-4284 (P) [92] } \\
\text { let-7f (P) [66] } \\
\text { let-7i (S/P) [66] } \\
\text { let-7b [66] }\end{array}$ & & RNU2-1f (S) [175] \\
\hline & Endometrial cancer & $\begin{array}{c}\text { miR-9, miR-92a, miR-99a, miR-100, miR-199b, miR-1228 (P) [176] } \\
\text { miR-9, miR-1228, miR-9, miR-92a (P) [177] } \\
\text { miR-21, miR-222, miR-223, miR-186 and miR-204 (S) [178,179] } \\
\text { miR-203 (S) [180] } \\
\text { miR-21 (S) [181] } \\
\text { miR-887-5p (S) [182] } \\
\text { miR-106b (U) [176] } \\
\text { miR-200c-3p (U) [183] }\end{array}$ & & \\
\hline
\end{tabular}


Table 1. Cont

\begin{tabular}{|c|c|c|c|c|}
\hline Cat. & Cancer Type & miRNA & piRNA & sn/snoRNA \\
\hline & Cervical cancer & $\begin{array}{c}\text { miR-101, miR-127, miR-142-3p, miR-150, miR-205, miR-21, miR-24, miR-425-5p, } \\
\text { miR-486-5p, miR-494 (S) [184] } \\
\text { miR-21, miR-146a, miR-155, miR-182, miR-200c, let-7b, miR-145 (S) [185] } \\
\text { miR-9, miR-10a, miR-20a, miR-196a (S) [186] } \\
\text { miR-21, miR-29a, miR-25, miR-200a, miR-486-5p (S) [187] } \\
\text { miR-92a (S) [188] } \\
\text { miR-646, miR-141-5p, miR-542-3p (S) [189] } \\
\text { miR-205 (S) [190] }\end{array}$ & & \\
\hline & Hodgkin Lymphoma & $\begin{array}{l}\text { miR-144, miR-143, miR-129-5p, miR-182, miR-411, miR-126-3p, miR-433, miR-23a, } \\
\text { miR-24, miR-423-5p (B) [191] }\end{array}$ & piR-651 (S) [192] & \\
\hline Haematologic & $\begin{array}{l}\text { Non-Hodgkin } \\
\text { Lymphoma }\end{array}$ & $\begin{array}{c}\text { miR-92a, miR-638 (P) [128] } \\
D L B C L \\
\text { miR-155, miR-210 (S); miR-221 (P)[66] } \\
\text { miR-15a, miR-16-1, miR-34a, miR-155, miR-29c (S) [128] } \\
\text { miR-425, miR-141, miR-197, miR-145, miR-345, miR-200c, miR-324-5p, let-7i-5, } \\
\text { miR-424, miR-222 (B), [191] } \\
\text { miR-34a-5p, miR-323b-3p, miR-431-5p, miR-125b, miR-130a, miR-155, miR-200c, } \\
\text { miR-29c, miR-145, miR-451, miR-17, miR-20b, miR-210, miR-296, miR-15a-3p, } \\
\text { miR-21-5p, miR-210-5p, miR-181a-5p, miR-155-5p, miR-210-3p, miR-16-1, miR-29c, } \\
\text { miR-155, miR-34a, miR-223, miR-155, miR-210 (S); miR-21 (S,P); miR-155 (EV from } \\
\text { serum)[193] } \\
\text { NTCL } \\
\text { miR-221 (P) [128] } \\
P N C S L \\
\text { miR-21 (S) [128] } \\
\text { miR-21, miR-19, and miR-92a (CSF) }\end{array}$ & & \\
\hline
\end{tabular}


Table 1. Cont.

\begin{tabular}{|c|c|c|c|c|}
\hline Cat. & Cancer Type & miRNA & piRNA & sn/snoRNA \\
\hline & Chronic leukemia & $\begin{array}{c}\text { CLL } \\
\text { let-7a, let-7c, let-7f, let-7g, let-7i, miR-10a, miR-15a, miR-19a, miR-20a, miR-21, } \\
\text { miR-22, miR-24, miR-26b, miR-29a, miR-29b, miR-29c, miR-30b, miR-31-5p, } \\
\text { miR-33, miR-34a, miR-34a-5p, miR-92, miR-95, miR-99a, miR-100, miR-101, } \\
\text { miR-106b, miR-107, miR-123, miR-125a, miR-125a, miR-126, miR-126, miR-130a, } \\
\text { miR-132, miR-134, miR-136, miR-138, miR-139, miR-140, miR-141, miR-142-5p, } \\
\text { miR-143, miR-146a, miR-147a, miR-148a, miR-150, miR-150-5p, miR-151-3p, } \\
\text { miR-154, miR-155, miR-155-5p, miR-181a, miR-181b, miR-182, miR-183, miR-184, } \\
\text { miR-185, miR-190, miR-191, miR-192, miR-193b, miR-196-2, miR-197, miR-198, } \\
\text { miR-199a, miR-206, miR-212, miR-217, miR-220, miR-223, miR-326, miR-323-3p, } \\
\text { miR-632, miR-337-3p, miR-338, miR-342-3p, miR-363, miR-367, miR-370, miR-374b, } \\
\text { miR-377, miR-424, miR-442, miR-451, miR-453, miR-484, miR-491, miR-494, } \\
\text { miR-572, miR-582-5p, miR-636, miR-640, miR-660, miR-923, miR-1201, miR-1202, } \\
\text { miR-1203, miR-3676 (B) [130] } \\
\text { miR-195, miR-199b, miR-320, miR-432, (P) [130] } \\
\text { CML } \\
\text { miR-17, miR-18a, miR-20a, miR-21, miR-27a, miR-155 (B) [195] } \\
\text { miR-122-5p, miR-16-5p, miR-451a and miR-92a-3p, miR-4644, miR-6075, miR-4656, } \\
\text { miR-5739 (B) [196] } \\
\text { miR-90, miR-150, miR-16, miR-17, miR-20, miR-21, miR-29, miR-92a, miR-101, } \\
\text { miR-106, miR-126, miR-146, miR-150, miR-152, miR-155, miR-451, miR-568, } \\
\text { miR-607 (B) [197] }\end{array}$ & & \\
\hline & Acute leukemia & $\begin{array}{c}\text { AML } \\
\text { miR-92a, miR-143, miR-342, miR-100, miR-196a, miR-146a, miR-29a, miR-142-3p, } \\
\text { miR-29a, miR-142-3p, miR-150, miR-342, miR-150, miR-342 (P) [128] } \\
\text { miR-21, miR-155, miR-210, miR-221, miR-10a-5p, miR-93-5p, miR-129-5p, } \\
\text { miR-155-5p, miR-181b-5p, miR-320d (S) [128] } \\
\text { ALL } \\
\text { miR-155 (S, P) [66] } \\
\text { miR-128b, miR-204, miR-218, miR-331, miR-135b, miR-132, miR-199, miR-139, } \\
\text { miR-150, miR-519e; miR-487b; miR-361; miR-142-3p; miR-222; miR-339, miR-451; } \\
\text { miR-373; miR-296; miR-485-3p; miR-483, miR-196a, miR-383, miR-542-5p, } \\
\text { miR-133a (B), miR-708, miR-511, miR-708, let-7b, miR-708, miR-210, miR-181b, } \\
\text { miR-345, miR-324-5p, and miR-125b, miR-23a, miR-27a, miR-23b, miR-24 (B) [198] }\end{array}$ & & \\
\hline
\end{tabular}


Table 1. Cont

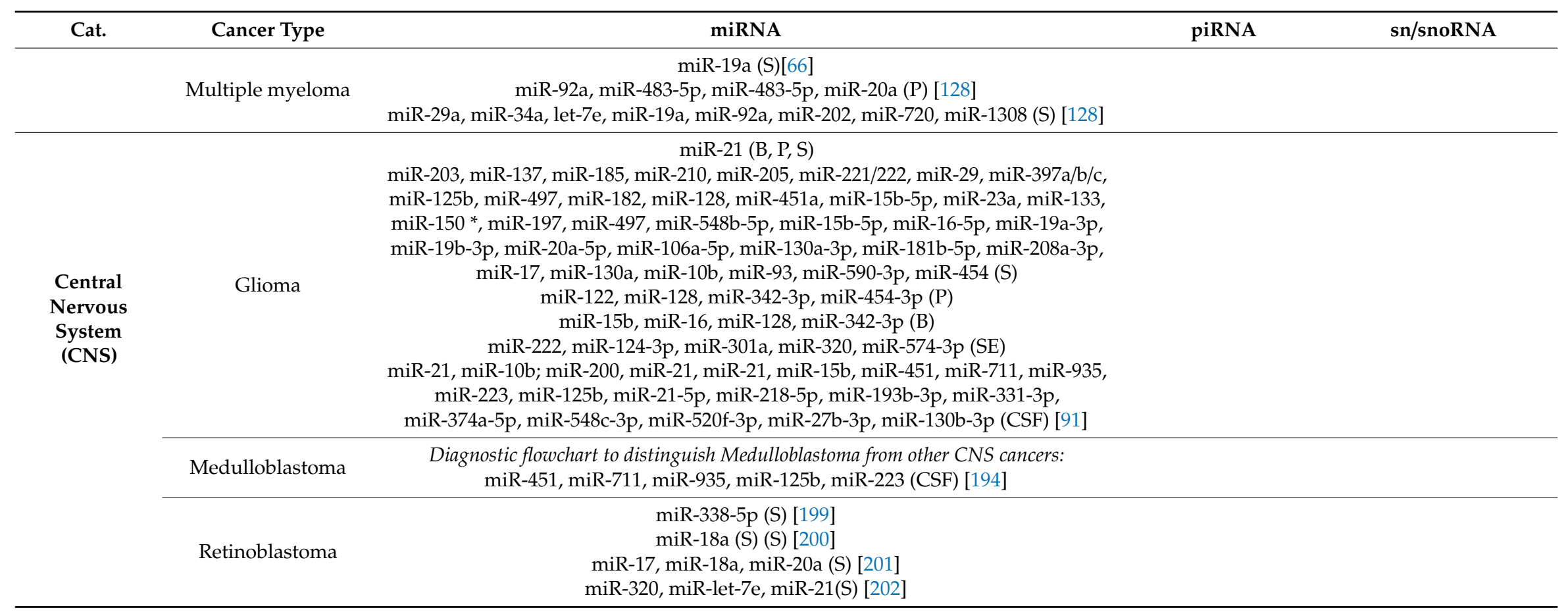


Table 1. Cont

\begin{tabular}{|c|c|c|c|c|}
\hline Cat. & Cancer Type & miRNA & piRNA & sn/snoRNA \\
\hline Endocrine & Thyroid cancer & $\begin{array}{c}\text { miR-25-3p, miR-451a (P) [203] } \\
\text { miR-346, miR-10a-5p, miR-34a-5p (P) [204] } \\
\text { miR-124-3p and miR-9-3p (P) [205] } \\
\text { miR-146b, miR-155 (P) [206] } \\
\text { miR-222, miR146b (P) [207] } \\
\text { miR-144, miR-34a (P) [208] } \\
\text { miR-222, miR-221, miR-146b, miR-21 (S) [209] } \\
\text { miR-95, miR-190 (S) [210] } \\
\text { miR-222, miR-221 miR-146b (S) [211] } \\
\text { miR-30a-5p (S) [212] } \\
\text { miR-95, miR-190 (S) [214] } \\
\text { miR-222 (S) [215] } \\
\text { miR-146a-5p, miR-199b-3p, let7b } 5 \text { (S) [213] } \\
\text { miR-375, miR-34a, miR-145b, miR-151-5p, miR-222 (S) [216] } \\
\text { miR-146b-5p, miR-222-3p, miR-155-5p, and miR-378a-3p (B) [218] } \\
\text { miR-21, miR-31, miR-181a-5p (PE) [218] }\end{array}$ & & \\
\hline
\end{tabular}


Table 1. Cont

\begin{tabular}{|c|c|c|c|c|}
\hline Cat. & Cancer Type & miRNA & piRNA & sn/snoRNA \\
\hline Bone & Osteosarcoma & $\begin{array}{c}\text { miR-487a, miR-493-5p, miR-501-3p and miR-502-5p (S) [219] } \\
\text { miR-25-3p (S) [220] } \\
\text { miR-215-5p, miR-642a-5p (S) [221] } \\
\text { miR-101 (S) [222] } \\
\text { miR-124 (S) [223] } \\
\text { miR-375 (S) [224] } \\
\text { miR-598 (S) [225] } \\
\text { miR-95-3p (S) [226] } \\
\text { miR-300 (S) [227] } \\
\text { miR-497 (S) [228] } \\
\text { miR-326 (S) [229] } \\
\text { miRNA-223 (S) [230] } \\
\text { miR-421 (S) [231] } \\
\text { miR-106a-5p, miR16-5p, miR-20a-5p, miR-425-5p, miR451a, miR-25-3p, } \\
\text { miR-152 (S) [233] } \\
\text { miR-191 (S) [234] } \\
\text { miR-221 (S) [235] } \\
\text { miR-199a-5p (S) [236] } \\
\text { miR-27a (S) [237] } \\
\text { miR-195 (S) [238] } \\
\text { miR-133b, miR-206 (S) [239] } \\
\text { miR-29a, miR-29b, miR-29c (S) [240] } \\
\text { miR-663a (P) [241] } \\
\text { miR-139-5p (P) [243] } \\
\text { miR-Let7a (B) [244] } \\
\text { miR-148a (B) [245] }\end{array}$ & & \\
\hline
\end{tabular}


Table 1. Cont

\begin{tabular}{|c|c|c|c|c|}
\hline Cat. & Cancer Type & miRNA & piRNA & sn/snoRNA \\
\hline Skin Cancers & Melanoma & $\begin{array}{l}\text { miR-1260a, miR-126-5p, miR-1280, miR-145-5p, miR-150-5p, miR-155-5p, } \\
\text { miR-16-5p, miR-182-5p, miR-193b-3p, miR-197-3p, miR-200c-3p, miR-204-5p, } \\
\text { miR-205-5p, miR-206, miR-211-5p, miR-211-5p, miR-221-3p, miR-22-3p, } \\
\text { miR-27a-3p, miR-28-5p, miR-301a-3p, miR-30b-5p, miR-373-5p, miR-374-5p, } \\
\text { miR-432-3p, miR-4487, miR-451a, miR-4706, miR-4731, miR-509-3p, miR-509-5p, } \\
\text { miR-550a-3p, miR-627-5p, miR-629-5p, miR629-5p, miR-720, miR-9-5p (S) [246] } \\
\text { miR-126-5p, miR-211-5p, miR-206, miR-16 miR-211, miR-182-5p, miR-301a-3p, } \\
\text { miR-193b-3p, miR-197-3p, miR-200c-3p, miR-204-5p, miR-28-5p, miR-27a-3p, } \\
\text { miR-29c-5p, miR-324-3p, miR-374a-5p, miR-4487, miR-4706, miR-4731, miR-509-3p, } \\
\text { miR-509-5p, miR-550a-3p, miR-627-5p, miR-629-5p, miR-720, miR-205-5p (S) [247] } \\
\text { miR-182-5p, miR-193b-3p, miR-200c-3p, miR-204-5p, miR-205-5p, miR-211-5p, } \\
\text { miR-301a-3p, miR-720 (S) [248] } \\
\text { miR-150-5p, miR-146a, miR-149-3p, miR-155, miR-15b-5p, miR-181a, miR-193a-3p, } \\
\text { miR-20a, miR-223, miR-524-5p, miR-125b (P) [247] } \\
\text { miR-1258, miR-1264, miR-1269a, miR-1302, miR-1306-5p, miR-138-5p, miR-152-3p, } \\
\text { miR-1537-3p, miR-154-5p, miR-1-5p, miR-181b-5p, miR-1910-5p, miR-1973, } \\
\text { miR-205-5p, miR-219a-2-3p, miR-2682-5p, miR-27a-3p, miR-299-3p, miR-301a-3p, } \\
\text { miR-3131, miR-337-5p, miR-34a-5p, miR-3928-3p, miR-424-5p, miR-431-5p, } \\
\text { miR-450a-5p, miR-4532, miR-454-3p, miR-4787-3p, miR-497-5p, miR-520d-3p, } \\
\text { miR-522-3p, miR-548a-5p, miR-548ad-3p, miR-5481, miR-553, miR-624-3p, miR-764 } \\
\text { (P) [249] } \\
\text { miR-134-5p, miR-320a-3p (P) [250] } \\
\text { miR-21-5p (P) [246] } \\
\text { miR-200c-3p (P, S) [246] }\end{array}$ & & \\
\hline
\end{tabular}

Abbreviations: SA = Saliva; P = Plasma, SE = Serum exosomes; $\mathrm{S}$ = Serum; PV = Plasma vesicles; $\mathrm{B}=$ Blood; $\mathrm{P}$ = Plasma exosomes; U = Urine; UE = Urine exosomes; SP = Sputum, $\mathrm{CSF}=$ Cerebrospinal fluid; $\mathrm{BC}=$ Blood cells; $\mathrm{F}=$ Feces; BI = Bile; $\mathrm{GJ}=$ Gastric Juice; TEP = Tumor educated platelets; $\mathrm{CRCR}=\mathrm{Colorectal}$ cancer; $\mathrm{DLBCL}=\mathrm{Diffuse}$ large B-cell lymphoma;

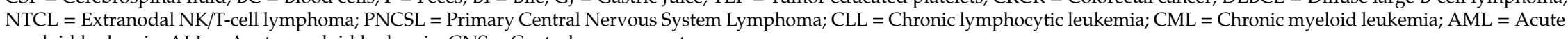
myeloid leukemia, ALL = Acute myeloid leukemia, $\mathrm{CNS}=$ Central nervous system. 


\section{PiRNAs in Biological Fluids}

piRNAs are a class of 26-31 nucleotide small ncRNAs that is transcribed from genome intergenic regions with a Dicer-dependent mechanism [251,252]. They are the largest known class of small ncRNAs [253-255] and work in transposon silencing and in specific transcriptional regulation functions. For example, it has been demonstrated their role in embryonic development and spermatogenesis [256]. piRNAs are 5-monophosphated and 2'-O-methyl, modified at the $3^{\prime}$ terminal, which are typical features of stable molecules [257]. They have a tissue-specific expression profile, and their abundance in cancer allowed researchers to hypothesize their involvement in cancer regulatory processes [251,258]. In one of the last estimates, the presence of different piRNAs encoded in mammalian genomes has been calculated, reaching up to tens of millions [259].

piRNAs have been found either in isolated exosomes or as free-circulating in serum, plasma, saliva, and stool $[27,260]$. Alterations in circulating piRNA expression levels may work as good cancer biomarkers, with higher sensitivity and specificity than circulating miRNAs [157]. Only a few studies investigated the role of piRNAs as cancer biomarkers in body fluids, and we report a selection of them in Table 1. The large majority of the reported studies were focused on piR-651 and piR-823, but the field is in continuous development and update.

High circulating piRNA levels have been found in gastric [157], colorectal [6,22,261], prostatic [26], and renal [172] cancers, but also in Hodgkin's Lymphoma [33]. piR-823, for example, was found up-regulated in serum and urine of renal carcinoma patients when compared with healthy controls [172]. piR-651 expression levels in serum were lower in Hodgkin's lymphoma patients than in healthy controls [192]. Finally, a set of piRNAs, altered in plasma-derived extracellular vesicles could characterize colorectal (piR-019825), prostate (piR-016658 and piR-020496), and pancreatic (piR-001311 and piR-016658) [26] cancers. Interestingly, 31 free-circulating piRNAs in serum were recently found to be significantly dysregulated in colorectal cancer (CRC) patients compared with healthy donors. The levels of piR-5937 and piR-28876, in particular, were able to differentiate between cancer patients and healthy donors with high sensitivity and specificity, and after chemotherapy treatment, the expression levels were again comparable between cases and controls. Vychytilova-Faltejskova et al. concluded that piRNAs could serve as promising noninvasive biomarkers for early detection of colon cancer [159].

\section{SnRNAs and SnoRNAs}

Small nuclear (snRNA) and small nucleolar (snoRNA) RNAs are components of the small ncRNAs transcriptome. Both are 60-300 nucleotides long and transcribed from intronic sequences of coding genes [262,263].

snRNAs are located in the cell nucleus and are fundamental in the RNA-RNA remodeling, in spliceosome assembly, being implicated in the translation process [262]. This class of molecules named "U(n)", based on their high Uridyl content (e.g., U1, U2-U12), form the spliceosome complex together with specific associated proteins (snRNPs). The spliceosome specifically binds to the pre-mRNA and precisely cleaves intron sequences, aiding the formation of a mature mRNA. During the formation of the spliceosome, snRNAs are implicated in complex RNA-RNA and RNA-protein interactions, which assure the correct binding to the pre-mRNA. Alterations in snRNA structure have been reported, and their functional consequences could be implied in the oncogenic process [264].

Table 1 reports the snRNAs that have been studied in liquid biopsies as cancer biomarkers. The best-known snRNA released into body fluids is U2: altered expression levels of fragments of RNU2 (RNU2-1f) have been detected in serum or plasma of lung, colorectal, pancreatic, and ovarian cancers $[156,163,164,175]$. Another potentially interesting snRNA that could serve as useful circulating biomarker for breast cancer is U6, which is overexpressed in breast cancer patients, independently of estrogen receptors (ER) status [174].

snoRNAs are hosted in introns of coding and noncoding transcripts $[265,266]$ and are implicated in the post-transcriptional modification of rRNA $[267,268]$. In recent years snoRNAs have been also recognized as involved in the formation of small nucleolar ribonucleoprotein particles (snoRNP) [262]. 
Additionally, there is some evidence that snoRNAs can act in miRNA-like post-transcriptional gene silencing [269]. Recently, the existence of cleavage products (20 to 30 base pair, similar in length to miRNAs) from $5^{\prime}$ or $3^{\prime}$ ends of snoRNAs have been described: these species have been termed sdRNA-sno-derived RNAs. The functional oncogenic implication of these products has been investigated in the cancer genome atlas (TCGA) samples, revealing a high sensitivity in distinguishing cancer types on the basis of sdRNA expression profiles. More than their possible use as biomarkers, major implications of these molecules in the oncogenic process, tumor immune milieu, patient prognostic, response to therapy, and aid in targeted therapy have been hypothesized and have a promising outlook, warranting future investigation [270,271].

Table 1 reports the snoRNAs that have been studied in liquid biopsies as cancer biomarkers. Regarding them, the available studies performed in liquid biopsies are mainly on lung cancer. SnoRD33, snoRD66, and snoRD76 were found up-regulated in plasma from NSCLC patients [161], while snoRD33, snoRD66, snoRD42, and snoRD78 were investigated in sputum samples of patients with the same type of cancer [162,272]. Recently, two snoRNAs (snoRA74A and snoRA25) detected in serum exosomes resulted as good biomarkers, able to distinguish pancreatic cancer patients from controls [155].

\section{LncRNAs}

IncRNAs constitute a heterogeneous group of noncoding transcripts of $>200$ nucleotides that may be distributed in various cellular compartments. They can be intragenic (intronic or antisense) or intergenic [273]. Some of them are stable and highly conserved, while others have a high turnover and are poorly conserved. The biological functions ascribed to this class of ncRNAs are various: from coordinating gene regulation at DNA/RNA level to regulation of protein biogenesis and function [273]. IncRNAs resulted importantly also in chromatin remodeling, as well as transcriptional and post-transcriptional control, interacting with RNA, DNA, and proteins as scaffolds, decoys, and enhancer RNAs. IncRNAs play an important role in carcinogenesis and metastasis, and they seem to be key players in cancer biology [274-276]. They are considered potential cancer diagnostic and prognostic factors [277], especially considering that lncRNAs are rather stable and can be detected in body fluids as circulating biomarkers for disease diagnosis $[278,279]$. Similarly to small ncRNAs, also lncRNAs can be carried through exosomes or other extracellular vesicles to disseminate signals, with the aim to change or regulate recipient cells either locally or at distance. Theoretically, the function of lncRNAs loaded into extracellular vesicles can work in a hormone-like fashion similarly to miRNAs, as we recently argued [23]. The number of investigations on circulating lncRNAs as cancer biomarkers has grown in the last 5-8 years. The most relevant works on this field are reported in Table 2 . The majority of the studies conducted on body fluids have been performed on serum/plasma [280-291], but only some researchers focused on extracellular- [292-294] and urine-derived lncRNAs [295-299], while some others focused on saliva [300,301], bile [302] and gastric juice [303].

In a recent work by Kamel et al., a significant down-regulation of growth-arrest-specific transcript 5 (GAS5) expression and up-regulation of SOX2 overlapping transcript (SOX2OT) have been observed in NSCLC patients when compared with controls [288].

Wang et al. recently published an interesting work focused on establishing the expression levels of colon cancer-associated transcript 2 (CCAT2) in CRC tissues, in serum and in exosomes derived from serum. The authors found that the levels of expression of this lncRNA were significantly over-expressed in CRC tumor tissues, and that this over-expression was reflected in serum and serum-derived exosomes of CRC patients when compared with healthy controls [293]. This data points out the large interest in CCAT2 that was observed in the last years. Indeed, the overexpression of this IncRNAs in transgenic mice led to spontaneous myeloid malignancies, while patients with myelodysplastic and myeloproliferative malignancies had high bone marrow and circulating levels of this IncRNA [304]. Interestingly, CCAT2 has been shown to be implicated in cancer metabolism by influencing the glutaminase splicing [305]. For more information regarding the implications of CCAT1 and CCAT2 in human cancers, please refer to [306]. 
Table 2. Long noncoding RNAs and circular RNAs with possible application as diagnostic biomarkers in body fluids.

\begin{tabular}{|c|c|c|c|}
\hline Cat. & Cancer Type & lncRNA & circRNA \\
\hline \multirow{6}{*}{ Digestive } & Oral cancer & $\begin{array}{c}\text { AC007271.3 (S) [307] } \\
\operatorname{HOTAIR}(\mathrm{SA})[300]\end{array}$ & $\begin{array}{l}\text { hsa_circ_0001874 (SA) [308] } \\
\text { hsa_circ_0001971 (SA) [308] } \\
\text { circMAN1A2 (S) [309] }\end{array}$ \\
\hline & Nasopharyngeal cancer & MALAT1, AFAP1-AS1, AL359062 (S) [310] & $\begin{array}{l}\text { circRNA_0000285 (S) [311] } \\
\text { circMAN1A2 (S) [309] }\end{array}$ \\
\hline & Esophageal cancer & $\begin{array}{c}\text { POU3F3; HNF1A-AS1; SPRY4-IT1 (P) [282] } \\
\text { MIR31HG (P), [312] } \\
\text { HOTAIR (S) [313] } \\
\text { POU3F3, SCCA (P) [282] }\end{array}$ & - \\
\hline & Hepatocellular carcinoma & $\begin{array}{c}\text { HULC (P) [281] } \\
\text { RP11-160H22.5, XLOC_014172, LOC149086 (P) [284] } \\
\text { SNHG18 (P) [286] } \\
\text { SNHG1 (P) [290] } \\
\text { GAS5-AS1 (P) [314] } \\
\text { ZFAS1 (P) [315] } \\
\text { DANCR (P) [316] } \\
\text { HULC, Linc00152 (P) [317] } \\
\text { SPRY4-IT1 (P) [318] } \\
\text { NEAT (S) [319] } \\
\text { LRB1 (S) [320] } \\
\text { UCA1 (S) [321] } \\
\text { X91348 (S) [322] } \\
\text { PVT1, uc002mbe.2 (S) [323] } \\
\text { uc001ncr, AX800134 (S) [324] } \\
\text { UCA1, WRAP53 (S) [325] } \\
\text { LINC00161 (S, SE, U) [326] }\end{array}$ & $\begin{array}{c}\text { hsa_circ_0001445 (P) [328] } \\
\text { circSMARCA5 (P) [329] }\end{array}$ \\
\hline & Cholangiocarcinoma & $\begin{array}{c}\text { PCAT1, MALAT1, CPS1-IT1 (P) [330] } \\
\text { ENST00000588480.1, ENST00000517758.1 (BI) [302] }\end{array}$ & - \\
\hline & Gallbladder carcinoma & - & - \\
\hline
\end{tabular}


Table 2. Cont.

\begin{tabular}{|c|c|c|c|}
\hline Cat. & Cancer Type & lncRNA & circRNA \\
\hline & Pancreatic cancer & $\begin{array}{c}\text { ABHD11-AS1, LINC00176, SNHG11 (P) [331] } \\
\text { HOTAIR, PVT1 (SA) [301] } \\
\text { HOTTIP-005, RP11-567G11.1 (P/S) [332] }\end{array}$ & $\operatorname{circLDLRAD3}(\mathrm{P})$ [333] \\
\hline & Gastric cancer & 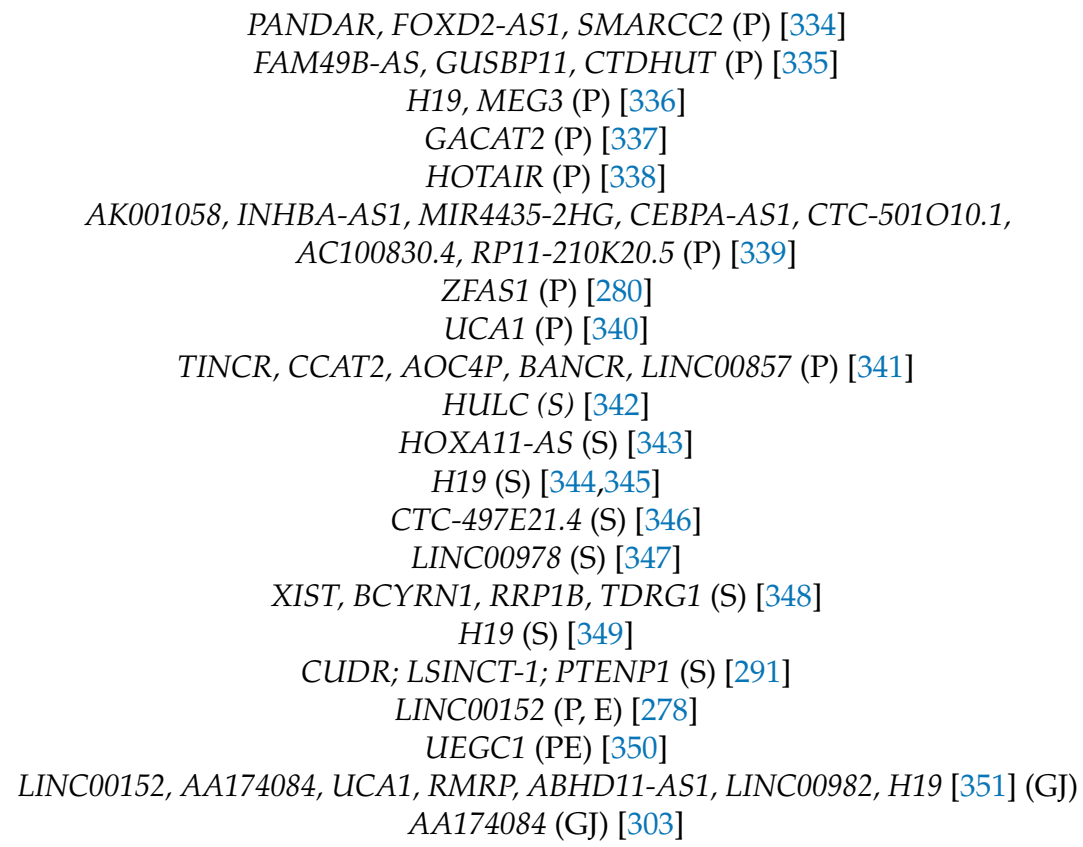 & $\begin{array}{c}\text { hsa_circ_0001649 (P) [352] } \\
\text { hsa_circ_0001017, hsa_circ_0061276 (P) } \\
\text { [353] } \\
\text { hsa_circ_0000745 (P) [354] } \\
\text { hsa_circ_0000520 (P) [355] } \\
\text { circ-KIAA1244 (P) [356] } \\
\text { hsa_circ_0000190 (P) [357] } \\
\text { hsa_circ_0000467 (P) [358] } \\
\text { hsa_circ_0000181 (P) [359] }\end{array}$ \\
\hline
\end{tabular}


Table 2. Cont.

\begin{tabular}{|c|c|c|c|}
\hline Cat. & Cancer Type & $\operatorname{lncRNA}$ & circRNA \\
\hline & Colorectal cancer (CRC) & 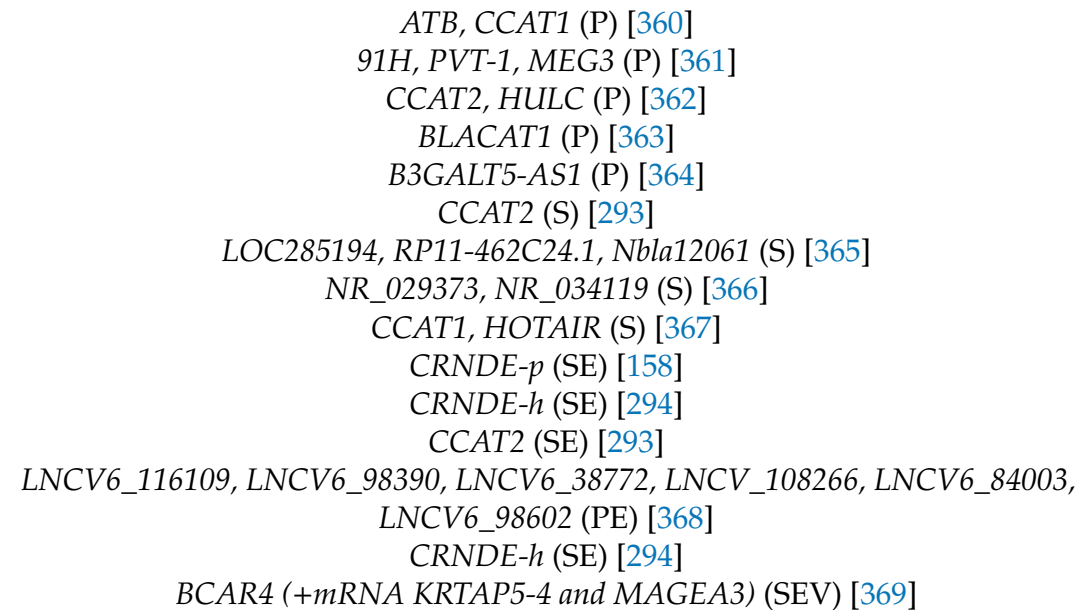 & $\begin{array}{c}\text { hsa_circ_0001649 (S) [370] } \\
\text { circVAPA (hsa_circ_0006990) (S) [371] }\end{array}$ \\
\hline
\end{tabular}


Table 2. Cont

\begin{tabular}{|c|c|c|c|}
\hline Cat. & Cancer Type & lncRNA & circRNA \\
\hline \multirow[t]{2}{*}{ Respiratory } & NSCLC & $\begin{array}{c}\text { GAS5, SOX2OT (P) [288] } \\
\text { H19 (P) [372] } \\
\text { HOTAIR (P) [373] } \\
\text { Linc00152 (P) [374] } \\
\text { SNHG1, RMRP (P) [375] } \\
\text { GAS5 (P) [376] } \\
\text { SPRY4-IT1, ANRIL, NEAT1 (P) [377] } \\
\text { RP11-397D12.4, AC007403.1, ERICH1-AS1 (P) [283] } \\
\text { UCA1 (P) [378] } \\
\text { RP11-397D12.4, AC007403.1, ERICH1-AS1 (P) [283] } \\
\text { TUG1 (S) [379] } \\
\text { PCAT6 (S) [380] } \\
\text { XIST, HIF1A-AS1 (S) [381] } \\
\text { AFAP1-AS1 (S) [382] } \\
\text { XLOC_O09167 (B) [384] } \\
\text { MALAT1 (SE) [292] } \\
\text { GAS5 (SE) [385] } \\
\text { SOX2-OT (PE) [386] } \\
\text { SOX2OT, ANRIL, CEA, CYFRA21-1, SCCA (S) [383] } \\
\text { SLC9A3-AS1, PCAT6 (EV from P) [387] }\end{array}$ & - \\
\hline & Laryngeal cancer & HOTAIR (S) [388] & - \\
\hline
\end{tabular}


Table 2. Cont.

\begin{tabular}{|c|c|c|c|}
\hline Cat. & Cancer Type & lncRNA & circRNA \\
\hline \multirow{3}{*}{ Urologic } & Renal cell carcinoma & $\begin{array}{c}\operatorname{lncARSR}(\mathrm{P})[285] \\
\text { LET, PVT1, PANDAR, PTENP1, linc00963 (S) [389] }\end{array}$ & - \\
\hline & Bladder cancer & $\begin{array}{c}\text { TUC338 (P) [390] } \\
H 19(\mathrm{SE})[391] \\
\text { PCAT-1, UBC1, SNHG16 (SE) [392] } \\
\text { H19 (U) [393] } \\
\text { (U) [173] } \\
\text { miR-497-HG (together with miR-324-5p, miR-4738-3p and RCAN1 FOSB mRNA) } \\
\text { uc004cox.4, GAS5 (U) [394] } \\
\text { HOTAIR, HOX-AS2, ANRIL, HYMA1, LINC00477, LOC100506688, OTX2-AS1 } \\
\text { (UE) [295] } \\
\text { UCA1-201, UCA1-203, MALAT1, LINC00355 (UE) [395] } \\
\text { MALAT1, PCAT-1, SPRY4-IT1 (UE) [396] } \\
\text { MEG3, SNHG16, MALAT1 (S) [397] }\end{array}$ & $\operatorname{circPRMT5}$ (SE, UE) [398] \\
\hline & Prostatic cancer & $\begin{array}{c}\text { TUC338 (P) [399] } \\
\text { BRE-AS1 (P) [400] } \\
\text { MALAT1 (P/S) [401] } \\
\text { PCA3/PSA (U) [402] } \\
\text { PRCAT17.3, PRCAT38 (U) [403] } \\
\text { PCA3, ERG (UE) [296,297,299] } \\
\text { TP53COR1 (UE) [298] } \\
\text { FR0348383 (U) [404] }\end{array}$ & - \\
\hline
\end{tabular}


Table 2. Cont

\begin{tabular}{|c|c|c|c|}
\hline Cat. & Cancer Type & lncRNA & circRNA \\
\hline \multirow{4}{*}{ Gynaecologic } & Breast cancer & $\begin{array}{c}\text { ANRIL, HIF1A-AS2, UCA1 (P) [287] } \\
\text { H19 (P) [405] } \\
\text { MALAT1 (S) [406] } \\
\text { RP11-445H22.4 (S) [407] }\end{array}$ & hsa_circ_0001785 (P) [408] \\
\hline & Ovarian cancer & - & $\operatorname{circMAN1A2~(S)~[309]~}$ \\
\hline & Endometrial cancer & - & $\begin{array}{l}\text { hsa_circ_0109046 (SEV) [409] } \\
\text { hsa_circ_0002577 (SEV) [409] }\end{array}$ \\
\hline & Cervical cancer & $\begin{array}{c}\text { FALEC (P) [410] } \\
\text { HOTAIR, PVT1, XLOC_000303, AL592284.1 (P) [411] } \\
\text { GIHCG (S) [412] } \\
\text { PVT1 (S) [413] }\end{array}$ & - \\
\hline \multirow{5}{*}{ Haematologic } & Hodgkin Lymphoma & - & - \\
\hline & Non-Hodgkin Lymphoma & - & - \\
\hline & Chronic leukemia & LincRNA-p21 (P) [289] & - \\
\hline & Acute leukemia & - & - \\
\hline & Multiple myeloma & $\begin{array}{c}\text { TUG1; MALAT1; HOTAIR; GAS5 (P) [289] } \\
\text { PCAT-1 (S) [414] } \\
\text { H19 (S) [415] }\end{array}$ & - \\
\hline \multirow{3}{*}{$\begin{array}{c}\text { Central } \\
\text { Nervous } \\
\text { System (CNS) }\end{array}$} & Glioma & $m i R 210 H G(S)$ [416] & - \\
\hline & Medulloblastoma & - & - \\
\hline & Retinoblastoma & - & - \\
\hline Endocrine & Thyroid cancer & GAS8-AS1 (P) [417] & $\begin{array}{c}\text { circMAN1A2 (S) [309] } \\
\text { hsacirc_007293, hsacirc_031752, } \\
\text { hsacirc_020135 (SE) [418] }\end{array}$ \\
\hline Bone & Osteosarcoma & UCA1 (S) [393] & hsa_circ_0000885 (S) [419] \\
\hline Skin Cancers & Melanoma & PVT1 (S) [420] & - \\
\hline
\end{tabular}


Another research group investigated the role of small nucleolar RNA host gene 18 (SNHG18) in HCC and found it downregulated in cancer tissues compared with paired adjacent noncancerous tissues. Interestingly, the down-regulation was also confirmed in plasma samples [286]. Other researchers found six aberrantly expressed lncRNAs in HCC tissues with respect to the corresponding normal tissues; however, only small nucleolar RNA host gene 1 (SNHG1) expression in cancer tissues correlated with the expression levels measured in plasma from the same patients. Interestingly, plasma SNHG1 expression levels correlated also with tumor size, TNM staging, and $\alpha$-fetoprotein levels, demonstrating its potential of being a reliable biomarker for the diagnosis of this cancer [290].

Recent reviews summarized findings regarding the implication of cell-free or exosome-derived lncRNAs [421-423] in several types of cancer, while specific reviews focused only on one type of cancer-nasopharyngeal [424], NSCLC [425], prostate [426-428], gastric [429], ovarian [430], bladder [431], and multiple myeloma [432]. In a recent meta-analysis on 28 studies, Dai et al. showed that circulating lncRNAs are more accurate markers for NSCLC compared with tissue samples, having an overall high diagnostic efficacy in the distinction of lung cancer [433]. Similar high diagnostic accuracy of lncRNAs was observed by Chen and collaborators in a metanalysis on circulating lncRNAs and HCC [434]. Regarding ovarian cancer, a systematic review based on tissue IncRNAs and survival has been done by Ning et al. [435]. However, to the best of our knowledge, none of the analyzed molecules have been investigated in serum samples. Finally, altered expression levels of FAM83H-AS1 were found in ovarian cancer tissue samples and proposed as potential circulating biomarkers [436].

A few studies proposed joint panels combining several ncRNAs for better accuracy in cancer diagnosis $[173,369]$. For example, Eissa et al. proposed a urine lncRNA, miR-497-HG, together with miR-324-5p, miR-4738-3p, and mRNA RCAN1 FOSB for bladder cancer diagnosis [173].

Notably, since 2012, urine determination of PCA3 (PROGENSA ${ }^{\circledR}$ ) is the only FDA-approved IncRNA used in the diagnostic process for prostate cancer [437-439], and, as it can be observed in the reported studies, the analysis of miRNAs and lncRNAs in urine-derived exosomes will continue to provide a sensitive resource in diagnosing malignancies of the bladder and prostate, with further promising application in the clinical field [57,295-299,401].

\section{CircRNAs}

Circular RNAs (circRNAs) are a class of lncRNAs characterized by the covalent linkage of their $5^{\prime}$ and $3^{\prime}$ moieties, which gives them a specific circular form [440] and makes them biologically stable and resistant to RNases [441]. They originate from intronic, exonic, intergenic regions, or exonic-intronic junctions and are formed by alternative mRNA backsplicing [442,443]. Although firstly reported in 1979 in human cells [444], for years they were considered splicing error by-products. However, in the last years, with the advent of NGS, they have been reconsidered, and their role as biomarkers rediscovered [445].

The major known biological function of circRNAs is related to gene expression regulation. They act in fact as sponges by competitively binding miRNAs. In this way, they can function as miRNA reservoirs, aid in miRNA transportation, or suppress miRNA binding to target genes [445]. circRNAs can also bind to RNA-binding proteins (RBPs), acting as protein sponges [446]. Moreover, by binding two or more proteins they can act as scaffolds, facilitating enzyme-substrate interaction [445]. As a consequence, circRNAs directly modulate gene expression at the transcriptional and post-transcriptional levels by interacting with elements of the spliceosome and by influencing the balance between canonical and alternative splicing. Therefore, there is a sort of passive competition between circRNAs and their relative linear mRNAs, generating a perturbation in the balance between transcripts, promoting aberrant expression of oncogenes and tumor suppressor genes [443,445].

The interaction between circRNAs, miRNAs, and RBPs is complex and not yet fully understood, posing difficulties in conceptualizing their dysregulation in pathologic situations [443]. However, circRNAs have been investigated in a wide range of diseases [447], including several types of cancer. The majority of the studies on circRNAs associated with cancer focused on tissue biopsies and 
cell lines, with a wide range of data reported (as reviewed by [448]). There are a few studies that searched for circRNAs only in body fluids $[309,356,408,409,418]$. The majority of works first detected circRNAs dysregulated in cancer tissues, and then tested if the same signature was reflected also in body fluids [311,328,329,333,352-355,357-359,370,371,398,419,449-451]. A recent systematic review on circRNAs included 77 studies and several types of cancers and emphasized the potential role as diagnostic biomarker of single and combined circRNAs with altered expression in plasma and serum [452]. All the circRNAs proposed as cancer diagnostic biomarkers in body fluids are reported in Table 2.

Nine circRNAs analyzed in plasma were found dysregulated in gastric cancer from several research groups (hsa_circ_0001017, hsa_circ_0061276 [353], hsa_circ_0000745 [354], hsa_circ_0000520 [355], hsa_circ_0000190 [357], hsa_circ_0001649 [352], circKIAA1244 [356], hsa_circ_0000467 [358], and hsa_circ_0000181 [359]. In particular, the first five circRNAs reported above were also recently confirmed by Jiang et al. in a metanalysis as dysregulated in plasma of gastric cancer patients [453].

In another study, the circMAN1A2 upregulation in serum was associated with several malignancies, with the highest diagnostic accuracy reported for nasopharyngeal carcinoma [309]. Interestingly, in the same type of cancer, also circRNA_0000285 resulted dysregulated in serum and has been reported as good diagnostic and prognostic marker for this tumor [311].

For CRC, two studies found a dysregulation of hsa_circ_0001649 [370] in serum and circVAPA [371] in plasma. For bladder cancer, circPRMT5 up-regulation in tissues was found also in serum and urine exosomes from the same patients [398]. For NSCLC, hsa_circ_0013958 [449], circFARSA [450], and hsa_circ_0005962 [451] were reported to be up-regulated in patients' plasma, while hsa_circ_0086414 [451] resulted down-regulated. Only one study investigated in plasma the expression levels of circRNAs in breast cancer, and hsa_circ_0001785 resulted the only specimen with altered expression in this body fluid [408]. On the other hand, hsa_circ_0109046 and hsa_circ_0002577 were reported as dysregulated in serum extracellular vesicles from endometrial cancer patients [409]. Other interesting results emerged for other circRNAs dysregulated in other cancers: hsa_circ_0001445 [328] and circSMARCA5 [329] in plasma from HCC patients; serum exosome hsa_circ_007293, hsa_circ_031752, and hsacirc_020135 in papillary thyroid carcinoma [418]; and serum hsa_circ_0000885 in osteosarcoma [419]. Interestingly, the up-regulation of circLDLRAD3 was reported as a putative diagnostic biomarker for pancreatic cancer [333].

Although circRNAs are very stable, and availability in various body fluids has been reported [454], their study as diagnostic biomarkers in liquid biopsies is mainly based on blood-derived specimens. Only few studies investigated circRNA profiles in other body fluids—saliva [260,308,455], gastric juice [456], and urine [398]. To our knowledge, no cancer circRNA profiling has been reported in feces or CSF.

For more information on the implications of circRNAs in cancer, and a critical approach regarding their use as biomarkers, we recommend referring to Dragomir and Calin [443] and Ragan et al. [445].

\section{Final Remarks and Future Perspectives}

Recent years brought notable advances in the research of ncRNA implications in the oncologic field. A plethora of studies focused on miRNAs, to investigate their involvement in oncogenesis and their potential use as diagnostic and prognostic markers, but also as therapeutic means. This enormous enthusiasm in miRNA investigation was not replicated to the same extent in the investigation of other ncRNAs. Some studies focused on the analysis of lncRNAs as biomarkers, while recent studies revealed new functions and implication of piRNAs in oncogenesis [457]. To date, the scientific community is trying to decipher and understand the complex pathways and interactions by which ncRNAs are implicated in oncogenesis. Many aspects regarding their role and importance need still to be clarified. For instance, it is not known the exact number of ncRNAs species in the human genome. For lncRNAs, it has been estimated a number that ranges from about 5000 to 53,000 species [458]; for miRNAs, 
there are at least 2000 known species [459], while it has been estimated about 50,000 piRNAs in the mammalian genome [460].

One of the most valuable uses of ncRNAs is as biomarkers for disease. Initially, studies focused on analyzing expression profiles in cancerous tissues. As a reaction, it was expected to find similar dysregulations also in body fluids, as a reflection of the presence of the disease in a surrogate tissue. However, not all findings were replicated in body fluids. To increase the specificity, researchers focused on isolating RNA from circulating exosomes, which indeed revealed more promising results, being an alternative mode of communication between neighboring and distant cells. In this paper, we reported also an overview of the signatures found in body fluids that are reflecting tumor tissue profiles, and their potential use in clinical medicine. Tumor-derived exosomes can originate and reach different cell types also to distant sites, influencing the biological activities of tumors, such as proliferation, invasion and metastasis, immunoregulation, generation of a premetastatic niche, and stimulation of angiogenesis [461]. Recent outcomes indicate that cancer-connected exosomes exhibit specific characteristics in educating macrophages, alter dysbiosis and exacerbate progression of CRC, implicating a role of the host defense system in cancer progression. At present, we are still far from clearly understanding the relationship between exosomes and macrophages and the recognition process; moreover, it is not yet clear how they can interact and influence the microbiome [462]. However, their functions are evidently affected by their cargo, which includes many RNA species including miRNAs and other ncRNAs.

Interestingly, ncRNAs have a potential application also as therapeutics in the near future. The replacement of the tumor suppressor miR-34a, by using a synthetic product, MRX34, was the first miRNA replacement therapy in a phase I clinical trial in humans, which initially reported promising results [463]. Since then, constant advances in using ncRNAs in cancer therapy are being made [464]. Besides being reported to be implicated in predicting chemo- and radioresistance, miRNAs and IncRNAs have been proposed as therapeutic targets, and miRNAs are being used in clinical trials [465]. For example, targeting miR-155 and TP53 in lung cancer improved therapeutic response in vitro [466]. Likewise, siRNA-mediated inhibition of EphA2, potentiated by miR-520d-3p replacement, acts as a tumor suppressor, both in vitro and in vivo [467]. Moreover, targeting miR-29b and miR-125 by suppressing Podoplanin, could aid in blocking invasiveness in glioblastoma [468]. Interactions between miRNAs and Toll-like receptors have been reported, underlining the implication of ncRNAs in cancer immunology [469]. Also, miRNA expression patterns are analyzed in order to better understand and direct immune checkpoint inhibitor therapy $[470,471]$. For more details on the application of ncRNAs as therapeutics, we recommend referring to [465,472].

With the development of NGS techniques, many researchers have embarked on genome/transcriptome sequencing from a wide set of samples. Due to this specific technology, new species of previously not described ncRNAs have been reported, including for example piRNAs, which have been discovered just in 2006 [457]. The advancements in this field may conduct to the discovery of new, more specific and sensitive molecules to be used as biomarkers and give new insights into the so-called "junk" DNA/RNA.

Although advances in the field are promising, we cannot help from noticing drawbacks in the NGS analyses process and in the research of biomarkers in body fluids. It must be noted that it is not uncommon to find studies focusing on the same type of cancer and analyzing the same body fluid that report contradictory results regarding ncRNA expression profiles, sometimes even in opposite directions of dysregulation. This phenomenon could be explained by the lack of uniformity in study designs, including differences in study group size, population study ethnicity [473], the inclusion or not of cancer risk factors such as smoking status [474], and gender [475]. All these features could influence study outcomes. Moreover, there is an enormous heterogeneity regarding technical steps towards the final results: RNA isolation procedure, exosome separation, NGS library preparation, sequencing, and bioinformatics/biostatistics approaches in analyzing and interpreting results. It is also difficult to establish the more suitable body fluids to be used for biomarker discovery in different 
types of cancers. Taking for instance CRC, stool would seem an ideal candidate to analyze, being the elected surrogate specimen; however, new studies are emerging on the analysis of sputum or saliva for the detection of biomarkers for CRC [476]. Other issues affecting the reproducibility of the data are directly connected with NGS. For RNA-seq the methodology of preparation of the libraries could be still very variable, and for the moment there is no uniformity in the pipeline of analysis.

Big improvements are now ongoing, and in the near future, we believe many of the drawbacks will be overcome with a better understanding of the ncRNAs' role as cancer biomarkers.

Supplementary Materials: The following data are available online at http://www.mdpi.com/2072-6694/11/8/1170/ s1, Table S1: (A) Comparison of miRNA-cancer associations in tissues and body fluids: T is associated only in tissues, B only in body fluids and BT in both; (B) Number of microRNAs associated to each cancer type in body fluids and/or tissues; (C) Number of cancer types associated to each microRNA in body fluids and/or tissues.

Author Contributions: Conceptualization, Writing-Original Draft Preparation, Review \& Editing, B.P., G.B., A.A.S. and G.A.C.

Funding: This research received no external funding.

Acknowledgments: B.P. was supported by a Fulbright Research Scholarships (year 2018) and a Fondazione CRT grant (Rif 2018.0648). A.A.S. was supported by a COST Action STSM fellowship (CA17118). G.B. was supported by the Ministero dell'Istruzione, dell'Università e della Ricerca - MIUR project "Dipartimenti di Eccellenza 2018 - 2022" (n D15D18000410001). G.A.C. is the Felix L. Haas Endowed Professor in Basic Science. Work in Dr Calin's laboratory is supported by National Institutes of Health (NIH/NCATS) grant UH3TR00943-01 through the NIH Common Fund, Office of Strategic Coordination (OSC), the NCI grants 1R01 CA182905-01 and 1R01CA222007-01A1, an NIGMS 1R01GM122775-01 grant, a U54 grant \#CA096297/CA096300 - UPR/MDACC Partnership for Excellence in Cancer Research 2016 Pilot Project, a Team DOD (CA160445P1) grant, a Chronic Lymphocytic Leukemia Moonshot Flagship project, a Sister Institution Network Fund (SINF) 2017 grant and the Estate of C.G. Johnson, Jr.

Conflicts of Interest: The authors declare no conflict of interest.

\section{References}

1. Strimbu, K.; Tavel, J.A. What are biomarkers? Curr. Opin. HIV AIDS 2010, 5, 463-466. [CrossRef] [PubMed]

2. Xi, X.; Li, T.; Huang, Y.; Sun, J.; Zhu, Y.; Yang, Y.; Lu, Z.J. RNA Biomarkers: Frontier of Precision Medicine for Cancer. Noncoding RNA 2017, 3, 9. [CrossRef] [PubMed]

3. Schwarzenbach, H.; Hoon, D.S.; Pantel, K. Cell-free nucleic acids as biomarkers in cancer patients. Nat. Rev. Cancer 2011, 11, 426-437. [CrossRef] [PubMed]

4. Sole, C.; Arnaiz, E.; Manterola, L.; Otaegui, D.; Lawrie, C.H. The circulating transcriptome as a source of cancer liquid biopsy biomarkers. Semin. Cancer Biol. 2019. [CrossRef] [PubMed]

5. Heitzer, E.; Haque, I.S.; Roberts, C.E.S.; Speicher, M.R. Current and future perspectives of liquid biopsies in genomics-driven oncology. Nat. Rev. Genet. 2019, 20, 71-88. [CrossRef] [PubMed]

6. Chang, Y.; Tolani, B.; Nie, X.; Zhi, X.; Hu, M.; He, B. Review of the clinical applications and technological advances of circulating tumor DNA in cancer monitoring. Ther. Clin. Risk Manag. 2017, 13, 1363-1374. [CrossRef] [PubMed]

7. Matullo, G.; Naccarati, A.; Pardini, B. MicroRNA expression profiling in bladder cancer: The challenge of next-generation sequencing in tissues and biofluids. Int. J. Cancer 2016, 138, 2334-2345. [CrossRef] [PubMed]

8. Vasilescu, C.; Dragomir, M.; Tanase, M.; Giza, D.; Purnichescu-Purtan, R.; Chen, M.; Yeung, S.-C.J.; Calin, G.A. Circulating miRNAs in sepsis-A network under attack: An in-silico prediction of the potential existence of miRNA sponges in sepsis. PLoS ONE 2017, 12, e0183334. [CrossRef] [PubMed]

9. Djebali, S.; Davis, C.A.; Merkel, A.; Dobin, A.; Lassmann, T.; Mortazavi, A.; Tanzer, A.; Lagarde, J.; Lin, W.; Schlesinger, F.; et al. Landscape of transcription in human cells. Nature 2012, 489, 101-108. [CrossRef]

10. Alexander, R.P.; Fang, G.; Rozowsky, J.; Snyder, M.; Gerstein, M.B. Annotating non-coding regions of the genome. Nat. Rev. Genet. 2010, 11, 559-571. [CrossRef] [PubMed]

11. Esteller, M. Non-coding RNAs in human disease. Nat. Rev. Genet. 2011, 12, 861-874. [CrossRef] [PubMed]

12. Izzotti, A.; Calin, G.A.; Steele, V.E.; Croce, C.M.; De Flora, S. Relationships of microRNA expression in mouse lung with age and exposure to cigarette smoke and light. FASEB J. 2009, 23, 3243-3250. [CrossRef] [PubMed] 
13. Ferdin, J.; Nishida, N.; Wu, X.; Nicoloso, M.S.; Shah, M.Y.; Devlin, C.; Ling, H.; Shimizu, M.; Kumar, K.; Cortez, M.A.; et al. HINCUTs in cancer: Hypoxia-induced noncoding ultraconserved transcripts. Cell Death Differ. 2013, 20, 1675-1687. [CrossRef] [PubMed]

14. Anfossi, S.; Babayan, A.; Pantel, K.; Calin, G.A. Clinical utility of circulating non-coding RNAs-An update. Nat. Rev. Clin. Oncol. 2018, 15, 541-563. [CrossRef] [PubMed]

15. Rigoutsos, I.; Lee, S.K.; Nam, S.Y.; Anfossi, S.; Pasculli, B.; Pichler, M.; Jing, Y.; Rodriguez-Aguayo, C.; Telonis, A.G.; Rossi, S.; et al. N-BLR, a primate-specific non-coding transcript leads to colorectal cancer invasion and migration. Genome Biol. 2017, 18, 98. [CrossRef] [PubMed]

16. Stark, R.; Grzelak, M.; Hadfield, J. RNA sequencing: The teenage years. Nat. Rev. Genet. 2019. [CrossRef] [PubMed]

17. Lo, K.W.; Lo, Y.M.; Leung, S.F.; Tsang, Y.S.; Chan, L.Y.; Johnson, P.J.; Hjelm, N.M.; Lee, J.C.; Huang, D.P. Analysis of cell-free Epstein-Barr virus associated RNA in the plasma of patients with nasopharyngeal carcinoma. Clin. Chem. 1999, 45, 1292-1294.

18. Kopreski, M.S.; Benko, F.A.; Kwak, L.W.; Gocke, C.D. Detection of tumor messenger RNA in the serum of patients with malignant melanoma. Clin. Cancer Res. Off. J. Am. Assoc. Cancer Res. 1999, 5, 1961-1965.

19. Holford, N.C.; Sandhu, H.S.; Thakkar, H.; Butt, A.N.; Swaminathan, R. Stability of $\beta$-Actin mRNA in Plasma. Ann. N. Y. Acad. Sci. 2008, 1137, 108-111. [CrossRef]

20. Fernando, M.R.; Norton, S.E.; Luna, K.K.; Lechner, J.M.; Qin, J. Stabilization of cell-free RNA in blood samples using a new collection device. Clin. Biochem. 2012, 45, 1497-1502. [CrossRef]

21. Lawrie, C.H.; Gal, S.; Dunlop, H.M.; Pushkaran, B.; Liggins, A.P.; Pulford, K.; Banham, A.H.; Pezzella, F.; Boultwood, J.; Wainscoat, J.S.; et al. Detection of elevated levels of tumour-associated microRNAs in serum of patients with diffuse large B-cell lymphoma. Br. J. Haematol. 2008, 141, 672-675. [CrossRef] [PubMed]

22. Mitchell, P.S.; Parkin, R.K.; Kroh, E.M.; Fritz, B.R.; Wyman, S.K.; Pogosova-Agadjanyan, E.L.; Peterson, A.; Noteboom, J.; O’Briant, K.C.; Allen, A.; et al. Circulating microRNAs as stable blood-based markers for cancer detection. Proc. Natl. Acad. Sci. USA 2008, 105, 10513-10518. [CrossRef] [PubMed]

23. Pardini, B.; Calin, G.A. MicroRNAs and Long Non-Coding RNAs and Their Hormone-Like Activities in Cancer. Cancers (Basel) 2019, 11, 378. [CrossRef] [PubMed]

24. Xu, R.; Rai, A.; Chen, M.; Suwakulsiri, W.; Greening, D.W.; Simpson, R.J. Extracellular vesicles in cancer-Implications for future improvements in cancer care. Nat. Rev. Clin. Oncol. 2018, 15, 617-638. [CrossRef] [PubMed]

25. Huang, X.; Yuan, T.; Tschannen, M.; Sun, Z.; Jacob, H.; Du, M.; Liang, M.; Dittmar, R.L.; Liu, Y.; Kohli, M.; et al. Characterization of human plasma-derived exosomal RNAs by deep sequencing. BMC Genom. 2013, 14, 319. [CrossRef] [PubMed]

26. Yuan, T.; Huang, X.; Woodcock, M.; Du, M.; Dittmar, R.; Wang, Y.; Tsai, S.; Kohli, M.; Boardman, L.; Patel, T.; et al. Plasma extracellular RNA profiles in healthy and cancer patients. Sci. Rep. 2016, 6, 19413. [CrossRef] [PubMed]

27. Ferrero, G.; Cordero, F.; Tarallo, S.; Arigoni, M.; Riccardo, F.; Gallo, G.; Ronco, G.; Allasia, M.; Kulkarni, N.; Matullo, G.; et al. Small non-coding RNA profiling in human biofluids and surrogate tissues from healthy individuals: Description of the diverse and most represented species. Oncotarget 2018, 9, 3097-3111. [CrossRef] [PubMed]

28. Yeri, A.; Courtright, A.; Reiman, R.; Carlson, E.; Beecroft, T.; Janss, A.; Siniard, A.; Richholt, R.; Balak, C.; Rozowsky, J.; et al. Total Extracellular Small RNA Profiles from Plasma, Saliva, and Urine of Healthy Subjects. Sci. Rep. 2017, 7, 44061. [CrossRef]

29. Freedman, J.E.; Gerstein, M.; Mick, E.; Rozowsky, J.; Levy, D.; Kitchen, R.; Das, S.; Shah, R.; Danielson, K.; Beaulieu, L.; et al. Diverse human extracellular RNAs are widely detected in human plasma. Nat. Commun. 2016, 7, 11106. [CrossRef]

30. Ben-Dov, I.Z.; Whalen, V.M.; Goilav, B.; Max, K.E.; Tuschl, T. Cell and Microvesicle Urine microRNA Deep Sequencing Profiles from Healthy Individuals: Observations with Potential Impact on Biomarker Studies. PLoS ONE 2016, 11, e0147249. [CrossRef]

31. Umu, S.U.; Langseth, H.; Bucher-Johannessen, C.; Fromm, B.; Keller, A.; Meese, E.; Lauritzen, M.; Leithaug, M.; Lyle, R.; Rounge, T.B. A comprehensive profile of circulating RNAs in human serum. RNA Biol. 2018, 15, 242-250. [CrossRef] [PubMed] 
32. Qin, Y.; Yao, J.; Wu, D.C.; Nottingham, R.M.; Mohr, S.; Hunicke-Smith, S.; Lambowitz, A.M. High-throughput sequencing of human plasma RNA by using thermostable group II intron reverse transcriptases. RNA 2016, 22, 111-128. [CrossRef] [PubMed]

33. Danielson, K.M.; Rubio, R.; Abderazzaq, F.; Das, S.; Wang, Y.E. High Throughput Sequencing of Extracellular RNA from Human Plasma. PLoS ONE 2017, 12, e0164644. [CrossRef] [PubMed]

34. Guo, Y.; Vickers, K.; Xiong, Y.; Zhao, S.; Sheng, Q.; Zhang, P.; Zhou, W.; Flynn, C.R. Comprehensive evaluation of extracellular small RNA isolation methods from serum in high throughput sequencing. BMC Genom. 2017, 18, 50. [CrossRef] [PubMed]

35. Turchinovich, A.; Weiz, L.; Langheinz, A.; Burwinkel, B. Characterization of extracellular circulating microRNA. Nucleic Acids Res. 2011, 39, 7223-7233. [CrossRef]

36. Valadi, H.; Ekstrom, K.; Bossios, A.; Sjostrand, M.; Lee, J.J.; Lotvall, J.O. Exosome-mediated transfer of mRNAs and microRNAs is a novel mechanism of genetic exchange between cells. Nat. Cell Biol. 2007, 9, 654-659. [CrossRef] [PubMed]

37. Arroyo, J.D.; Chevillet, J.R.; Kroh, E.M.; Ruf, I.K.; Pritchard, C.C.; Gibson, D.F.; Mitchell, P.S.; Bennett, C.F.; Pogosova-Agadjanyan, E.L.; Stirewalt, D.L.; et al. Argonaute2 complexes carry a population of circulating microRNAs independent of vesicles in human plasma. Proc. Natl. Acad. Sci. USA 2011, 108, 5003-5008. [CrossRef]

38. Lobb, R.J.; Hastie, M.L.; Norris, E.L.; van Amerongen, R.; Gorman, J.J.; Moller, A. Oncogenic transformation of lung cells results in distinct exosome protein profile similar to the cell of origin. Proteomics 2017, 17. [CrossRef]

39. Ma, P.; Pan, Y.; Li, W.; Sun, C.; Liu, J.; Xu, T.; Shu, Y. Extracellular vesicles-mediated noncoding RNAs transfer in cancer. J. Hematol. Oncol. 2017, 10, 57. [CrossRef]

40. Yu, Z.; Zhao, S.; Ren, L.; Wang, L.; Chen, Z.; Hoffman, R.M.; Zhou, J. Pancreatic cancer-derived exosomes promote tumor metastasis and liver pre-metastatic niche formation. Oncotarget 2017, 8, 63461-63483. [CrossRef]

41. Barile, L.; Vassalli, G. Exosomes: Therapy delivery tools and biomarkers of diseases. Pharmacol. Ther. 2017, 174, 63-78. [CrossRef]

42. Takahashi, K.; Yan, I.K.; Wood, J.; Haga, H.; Patel, T. Involvement of extracellular vesicle long noncoding RNA (linc-VLDLR) in tumor cell responses to chemotherapy. Mol. Cancer Res. MCR 2014, 12, 1377-1387. [CrossRef]

43. Takahashi, K.; Yan, I.K.; Kogure, T.; Haga, H.; Patel, T. Extracellular vesicle-mediated transfer of long non-coding RNA ROR modulates chemosensitivity in human hepatocellular cancer. FEBS Open Bio 2014, 4, 458-467. [CrossRef]

44. Bullock, M.D.; Silva, A.M.; Kanlikilicer-Unaldi, P.; Filant, J.; Rashed, M.H.; Sood, A.K.; Lopez-Berestein, G.; Calin, G.A. Exosomal Non-Coding RNAs: Diagnostic, Prognostic and Therapeutic Applications in Cancer. Noncoding RNA 2015, 1, 53-68. [CrossRef]

45. Krol, J.; Loedige, I.; Filipowicz, W. The widespread regulation of microRNA biogenesis, function and decay. Nat. Rev. Genet. 2010, 11, 597-610. [CrossRef]

46. Bartel, D.P.; Chen, C.Z. Micromanagers of gene expression: The potentially widespread influence of metazoan microRNAs. Nat. Rev. Genet. 2004, 5, 396-400. [CrossRef]

47. Thomson, J.M.; Newman, M.; Parker, J.S.; Morin-Kensicki, E.M.; Wright, T.; Hammond, S.M. Extensive post-transcriptional regulation of microRNAs and its implications for cancer. Genes Dev. 2006, 20, 2202-2207. [CrossRef]

48. Awad, H.; Bratasz, A.; Nuovo, G.; Burry, R.; Meng, X.; Kelani, H.; Brown, M.; Ramadan, M.E.; Williams, J.; Bouhliqah, L.; et al. MiR-155 deletion reduces ischemia-induced paralysis in an aortic aneurysm repair mouse model: Utility of immunohistochemistry and histopathology in understanding etiology of spinal cord paralysis. Ann. Diagn. Pathol. 2018, 36, 12-20. [CrossRef]

49. Fabbri, M.; Garzon, R.; Andreeff, M.; Kantarjian, H.M.; Garcia-Manero, G.; Calin, G.A. MicroRNAs and noncoding RNAs in hematological malignancies: Molecular, clinical and therapeutic implications. Leukemia 2008, 22, 1095-1105. [CrossRef]

50. Calin, G.A.; Croce, C.M. Genomics of chronic lymphocytic leukemia microRNAs as new players with clinical significance. Semin. Oncol. 2006, 33, 167-173. [CrossRef] 
51. Sevignani, C.; Calin, G.A.; Nnadi, S.C.; Shimizu, M.; Davuluri, R.V.; Hyslop, T.; Demant, P.; Croce, C.M.; Siracusa, L.D. MicroRNA genes are frequently located near mouse cancer susceptibility loci. Proc. Natl. Acad. Sci. USA 2007, 104, 8017-8022. [CrossRef]

52. Chen, X.; Ba, Y.; Ma, L.; Cai, X.; Yin, Y.; Wang, K.; Guo, J.; Zhang, Y.; Chen, J.; Guo, X.; et al. Characterization of microRNAs in serum: A novel class of biomarkers for diagnosis of cancer and other diseases. Cell Res. 2008, 18, 997-1006. [CrossRef]

53. Munker, R.; Calin, G.A. MicroRNA profiling in cancer. Clin. Sci. (Lond.) 2011, 121, 141-158. [CrossRef]

54. Cogswell, J.P.; Ward, J.; Taylor, I.A.; Waters, M.; Shi, Y.; Cannon, B.; Kelnar, K.; Kemppainen, J.; Brown, D.; Chen, C.; et al. Identification of miRNA changes in Alzheimer's disease brain and CSF yields putative biomarkers and insights into disease pathways. J. Alzheimer's Dis. JAD 2008, 14, 27-41. [CrossRef]

55. Gallo, A.; Tandon, M.; Alevizos, I.; Illei, G.G. The majority of microRNAs detectable in serum and saliva is concentrated in exosomes. PLoS ONE 2012, 7, e30679. [CrossRef]

56. Zhou, Q.; Li, M.; Wang, X.; Li, Q.; Wang, T.; Zhu, Q.; Zhou, X.; Gao, X.; Li, X. Immune-related microRNAs are abundant in breast milk exosomes. Int. J. Biol. Sci. 2012, 8, 118-123. [CrossRef]

57. Pardini, B.; Cordero, F.; Naccarati, A.; Viberti, C.; Birolo, G.; Oderda, M.; Di Gaetano, C.; Arigoni, M.; Martina, F.; Calogero, R.A.; et al. microRNA profiles in urine by next-generation sequencing can stratify bladder cancer subtypes. Oncotarget 2018, 9, 20658-20669. [CrossRef]

58. Da Silveira, J.C.; Veeramachaneni, D.N.; Winger, Q.A.; Carnevale, E.M.; Bouma, G.J. Cell-secreted vesicles in equine ovarian follicular fluid contain miRNAs and proteins: A possible new form of cell communication within the ovarian follicle. Biol. Reprod. 2012, 86, 71. [CrossRef]

59. Iftikhar, H.; Carney, G.E. Evidence and potential in vivo functions for biofluid miRNAs: From expression profiling to functional testing: Potential roles of extracellular miRNAs as indicators of physiological change and as agents of intercellular information exchange. Bioessays 2016, 38, 367-378. [CrossRef]

60. Anfossi, S.; Fu, X.; Nagvekar, R.; Calin, G.A. MicroRNAs, Regulatory Messengers Inside and Outside Cancer Cells. Adv. Exp. Med. Biol. 2018, 1056, 87-108. [CrossRef]

61. Bullrich, F.; Fujii, H.; Calin, G.; Mabuchi, H.; Negrini, M.; Pekarsky, Y.; Rassenti, L.; Alder, H.; Reed, J.C.; Keating, M.J.; et al. Characterization of the 13q14 tumor suppressor locus in CLL: Identification of ALT1, an alternative splice variant of the LEU2 gene. Cancer Res. 2001, 61, 6640-6648.

62. Mittelbrunn, M.; Gutierrez-Vazquez, C.; Villarroya-Beltri, C.; Gonzalez, S.; Sanchez-Cabo, F.; Gonzalez, M.A.; Bernad, A.; Sanchez-Madrid, F. Unidirectional transfer of microRNA-loaded exosomes from T cells to antigen-presenting cells. Nat. Commun. 2011, 2, 282. [CrossRef]

63. Katakowski, M.; Buller, B.; Wang, X.; Rogers, T.; Chopp, M. Functional microRNA is transferred between glioma cells. Cancer Res. 2010, 70, 8259-8263. [CrossRef]

64. Redis, R.S.; Calin, S.; Yang, Y.; You, M.J.; Calin, G.A. Cell-to-cell miRNA transfer: From body homeostasis to therapy. Pharmacol. Ther. 2012, 136, 169-174. [CrossRef]

65. Hornick, N.I.; Huan, J.; Doron, B.; Goloviznina, N.A.; Lapidus, J.; Chang, B.H.; Kurre, P. Serum Exosome MicroRNA as a Minimally-Invasive Early Biomarker of AML. Sci. Rep. 2015, 5, 11295. [CrossRef]

66. Larrea, E.; Sole, C.; Manterola, L.; Goicoechea, I.; Armesto, M.; Arestin, M.; Caffarel, M.M.; Araujo, A.M.; Araiz, M.; Fernandez-Mercado, M.; et al. New Concepts in Cancer Biomarkers: Circulating miRNAs in Liquid Biopsies. Int. J. Mol. Sci. 2016, 17, 627. [CrossRef]

67. Thind, A.; Wilson, C. Exosomal miRNAs as cancer biomarkers and therapeutic targets. J. Extracell. Vesicles 2016, 5, 31292. [CrossRef]

68. Sohn, W.; Kim, J.; Kang, S.H.; Yang, S.R.; Cho, J.Y.; Cho, H.C.; Shim, S.G.; Paik, Y.H. Serum exosomal microRNAs as novel biomarkers for hepatocellular carcinoma. Exp. Mol. Med. 2015, 47, e184. [CrossRef]

69. Xu, J.; Cao, Z.; Liu, W.; You, L.; Zhou, L.; Wang, C.; Lou, W.; Sun, B.; Miao, Y.; Liu, X.; et al. Plasma miRNAs Effectively Distinguish Patients With Pancreatic Cancer From Controls: A Multicenter Study. Ann. Surg. 2016, 263, 1173-1179. [CrossRef]

70. Cao, Z.; Liu, C.; Xu, J.; You, L.; Wang, C.; Lou, W.; Sun, B.; Miao, Y.; Liu, X.; Wang, X.; et al. Plasma microRNA panels to diagnose pancreatic cancer: Results from a multicenter study. Oncotarget 2016, 7, 41575-41583. [CrossRef]

71. Komatsu, S.; Ichikawa, D.; Miyamae, M.; Kawaguchi, T.; Morimura, R.; Hirajima, S.; Okajima, W.; Ohashi, T.; Imamura, T.; Konishi, H.; et al. Malignant potential in pancreatic neoplasm; new insights provided by circulating miR-223 in plasma. Expert Opin. Biol. Ther. 2015, 15, 773-785. [CrossRef] 
72. Chen, Q.; Yang, L.; Xiao, Y.; Zhu, J.; Li, Z. Circulating microRNA-182 in plasma and its potential diagnostic and prognostic value for pancreatic cancer. Med. Oncol. 2014, 31, 225. [CrossRef]

73. Cote, G.A.; Gore, A.J.; McElyea, S.D.; Heathers, L.E.; Xu, H.; Sherman, S.; Korc, M. A pilot study to develop a diagnostic test for pancreatic ductal adenocarcinoma based on differential expression of select miRNA in plasma and bile. Am. J. Gastroenterol. 2014, 109, 1942-1952. [CrossRef]

74. Li, A.; Yu, J.; Kim, H.; Wolfgang, C.L.; Canto, M.I.; Hruban, R.H.; Goggins, M. MicroRNA array analysis finds elevated serum miR-1290 accurately distinguishes patients with low-stage pancreatic cancer from healthy and disease controls. Clin. Cancer Res. Off. J. Am. Assoc. Cancer Res. 2013, 19, 3600-3610. [CrossRef]

75. Zhao, C.; Zhang, J.; Zhang, S.; Yu, D.; Chen, Y.; Liu, Q.; Shi, M.; Ni, C.; Zhu, M. Diagnostic and biological significance of microRNA-192 in pancreatic ductal adenocarcinoma. Oncol. Rep. 2013, 30, 276-284. [CrossRef]

76. Bhat, S.A.; Majid, S.; Rehman, M.U. Scenario and future prospects of microRNAs in gastric cancer: A review. Iran. J. Basic Med. Sci. 2019, 22, 345-352. [CrossRef]

77. Zeng, Z.; Li, Y.; Pan, Y.; Lan, X.; Song, F.; Sun, J.; Zhou, K.; Liu, X.; Ren, X.; Wang, F.; et al. Cancer-derived exosomal miR-25-3p promotes pre-metastatic niche formation by inducing vascular permeability and angiogenesis. Nat. Commun. 2018, 9, 5395. [CrossRef]

78. Liu, X.; Pan, B.; Sun, L.; Chen, X.; Zeng, K.; Hu, X.; Xu, T.; Xu, M.; Wang, S. Circulating Exosomal miR-27a and miR-130a Act as Novel Diagnostic and Prognostic Biomarkers of Colorectal Cancer. Cancer Epidemiol. Biomark. Prev. Publ. Am. Assoc. Cancer Res. Cosponsored Am. Soc. Prev. Oncol. 2018, 27, 746-754. [CrossRef]

79. Kral, J.; Korenkova, V.; Novosadova, V.; Langerova, L.; Schneiderova, M.; Liska, V.; Levy, M.; Veskrnova, V.; Spicak, J.; Opattova, A.; et al. Expression profile of miR-17/92 cluster is predictive of treatment response in rectal cancer. Carcinogenesis 2018, 39, 1359-1367. [CrossRef]

80. Tsukamoto, M.; Iinuma, H.; Yagi, T.; Matsuda, K.; Hashiguchi, Y. Circulating Exosomal MicroRNA-21 as a Biomarker in Each Tumor Stage of Colorectal Cancer. Oncology 2017, 92, 360-370. [CrossRef]

81. Ren, D.; Lin, B.; Zhang, X.; Peng, Y.; Ye, Z.; Ma, Y.; Liang, Y.; Cao, L.; Li, X.; Li, R.; et al. Maintenance of cancer stemness by miR-196b-5p contributes to chemoresistance of colorectal cancer cells via activating STAT3 signaling pathway. Oncotarget 2017, 8, 49807-49823. [CrossRef] [PubMed]

82. Li, J.; Chen, Y.; Guo, X.; Zhou, L.; Jia, Z.; Peng, Z.; Tang, Y.; Liu, W.; Zhu, B.; Wang, L.; et al. GPC1 exosome and its regulatory miRNAs are specific markers for the detection and target therapy of colorectal cancer. $J$. Cell. Mol. Med. 2017, 21, 838-847. [CrossRef] [PubMed]

83. Nadal, E.; Truini, A.; Nakata, A.; Lin, J.; Reddy, R.M.; Chang, A.C.; Ramnath, N.; Gotoh, N.; Beer, D.G.; Chen, G. A Novel Serum 4-microRNA Signature for Lung Cancer Detection. Sci. Rep. 2015, 5, 12464. [CrossRef] [PubMed]

84. Moltzahn, F.; Olshen, A.B.; Baehner, L.; Peek, A.; Fong, L.; Stoppler, H.; Simko, J.; Hilton, J.F.; Carroll, P.; Blelloch, R. Microfluidic-based multiplex qRT-PCR identifies diagnostic and prognostic microRNA signatures in the sera of prostate cancer patients. Cancer Res. 2011, 71, 550-560. [CrossRef] [PubMed]

85. Lodes, M.J.; Caraballo, M.; Suciu, D.; Munro, S.; Kumar, A.; Anderson, B. Detection of cancer with serum miRNAs on an oligonucleotide microarray. PLoS ONE 2009, 4, e6229. [CrossRef] [PubMed]

86. Hessvik, N.P.; Sandvig, K.; Llorente, A. Exosomal miRNAs as Biomarkers for Prostate Cancer. Front. Genet. 2013, 4, 36. [CrossRef] [PubMed]

87. Samsonov, R.; Shtam, T.; Burdakov, V.; Glotov, A.; Tsyrlina, E.; Berstein, L.; Nosov, A.; Evtushenko, V.; Filatov, M.; Malek, A. Lectin-induced agglutination method of urinary exosomes isolation followed by mi-RNA analysis: Application for prostate cancer diagnostic. Prostate 2016, 76, 68-79. [CrossRef] [PubMed]

88. Ahadi, A.; Brennan, S.; Kennedy, P.J.; Hutvagner, G.; Tran, N. Long non-coding RNAs harboring miRNA seed regions are enriched in prostate cancer exosomes. Sci. Rep. 2016, 6, 24922. [CrossRef]

89. Mello-Grand, M.; Gregnanin, I.; Sacchetto, L.; Ostano, P.; Zitella, A.; Bottoni, G.; Oderda, M.; Marra, G.; Munegato, S.; Pardini, B.; et al. Circulating microRNAs combined with PSA for accurate and non-invasive prostate cancer detection. Carcinogenesis 2019, 40, 246-253. [CrossRef]

90. Hamam, R.; Hamam, D.; Alsaleh, K.A.; Kassem, M.; Zaher, W.; Alfayez, M.; Aldahmash, A.; Alajez, N.M. Circulating microRNAs in breast cancer: Novel diagnostic and prognostic biomarkers. Cell Death Dis. 2017, 8, e3045. [CrossRef]

91. Petrescu, G.E.D.; Sabo, A.A.; Torsin, L.I.; Calin, G.A.; Dragomir, M.P. MicroRNA based theranostics for brain cancer: Basic principles. J. Exp. Clin. Cancer Res. CR 2019, 38, 231. [CrossRef] 
92. Giannopoulou, L.; Kasimir-Bauer, S.; Lianidou, E.S. Liquid biopsy in ovarian cancer: Recent advances on circulating tumor cells and circulating tumor DNA. Clin. Chem. Lab. Med. 2018, 56, 186-197. [CrossRef]

93. Andreu, Z.; Otta Oshiro, R.; Redruello, A.; Lopez-Martin, S.; Gutierrez-Vazquez, C.; Morato, E.; Marina, A.I.; Olivier Gomez, C.; Yanez-Mo, M. Extracellular vesicles as a source for non-invasive biomarkers in bladder cancer progression. Eur. J. Pharm. Sci. Off. J. Eur. Fed. Pharm. Sci. 2017, 98, 70-79. [CrossRef]

94. Matsuzaki, K.; Fujita, K.; Jingushi, K.; Kawashima, A.; Ujike, T.; Nagahara, A.; Ueda, Y.; Tanigawa, G.; Yoshioka, I.; Ueda, K.; et al. MiR-21-5p in urinary extracellular vesicles is a novel biomarker of urothelial carcinoma. Oncotarget 2017, 8, 24668-24678. [CrossRef]

95. Foj, L.; Ferrer, F.; Serra, M.; Arevalo, A.; Gavagnach, M.; Gimenez, N.; Filella, X. Exosomal and Non-Exosomal Urinary miRNAs in Prostate Cancer Detection and Prognosis. Prostate 2017, 77, 573-583. [CrossRef]

96. Rodriguez, M.; Bajo-Santos, C.; Hessvik, N.P.; Lorenz, S.; Fromm, B.; Berge, V.; Sandvig, K.; Line, A.; Llorente, A. Identification of non-invasive miRNAs biomarkers for prostate cancer by deep sequencing analysis of urinary exosomes. Mol. Cancer 2017, 16, 156. [CrossRef]

97. Park, N.J.; Zhou, H.; Elashoff, D.; Henson, B.S.; Kastratovic, D.A.; Abemayor, E.; Wong, D.T. Salivary microRNA: Discovery, characterization, and clinical utility for oral cancer detection. Clin. Cancer Res. Off. J. Am. Assoc. Cancer Res. 2009, 15, 5473-5477. [CrossRef]

98. Kumarswamy, R.; Volkmann, I.; Thum, T. Regulation and function of miRNA-21 in health and disease. RNA Biol. 2011, 8, 706-713. [CrossRef]

99. Shen, M.M.; Abate-Shen, C. Molecular genetics of prostate cancer: New prospects for old challenges. Genes Dev. 2010, 24, 1967-2000. [CrossRef]

100. Taylor, D.D.; Gercel-Taylor, C. MicroRNA signatures of tumor-derived exosomes as diagnostic biomarkers of ovarian cancer. Gynecol. Oncol. 2008, 110, 13-21. [CrossRef]

101. Chen, A.; Wang, L.; Li, B.Y.; Sherman, J.; Ryu, J.E.; Hamamura, K.; Liu, Y.; Nakshatri, H.; Yokota, H. Reduction in Migratory Phenotype in a Metastasized Breast Cancer Cell Line via Downregulation of S100A4 and GRM3. Sci. Rep. 2017, 7, 3459. [CrossRef]

102. Giannopoulou, L.; Zavridou, M.; Kasimir-Bauer, S.; Lianidou, E.S. Liquid biopsy in ovarian cancer: The potential of circulating miRNAs and exosomes. Transl. Res. J. Lab. Clin. Med. 2019, 205, 77-91. [CrossRef]

103. Xie, B.; Ding, Q.; Han, H.; Wu, D. miRCancer: A microRNA-cancer association database constructed by text mining on literature. Bioinformatics 2013, 29, 638-644. [CrossRef]

104. Big Data Analytics in Bioinformatics and Healthcare; Baoying, W.; Ruowang, L.; William, P. (Eds.) IGI Global: Hershey, PA, USA, 2015; pp. 1-528.

105. Xie, B.; Hochberg, R.; Ding, Q.; Wu, D. miRSAT \& miRCDB: An Integrated MicroRNA Sequesce Analysis Tool and a Cancer-Associated MicroRNA Database. In Proceedings of the ISCA 2nd International Conference on Bioinformatics and Computational Biology, BICoB-2010, Honolulu, HI, USA, 24-26 March 2010; pp. 159-164.

106. Choudhury, S.N.; Li, Y. miR-21 and let-7 in the Ras and NF-kappaB pathways. Microrna 2012, 1, 65-69. [CrossRef]

107. O'Connell, R.M.; Chaudhuri, A.A.; Rao, D.S.; Baltimore, D. Inositol phosphatase SHIP1 is a primary target of miR-155. Proc. Natl. Acad. Sci. USA 2009, 106, 7113-7118. [CrossRef]

108. Fernandez-Mercado, M.; Manterola, L.; Lawrie, C.H. MicroRNAs in Lymphoma: Regulatory Role and Biomarker Potential. Curr. Genom. 2015, 16, 349-358. [CrossRef]

109. Zhi, F.; Shao, N.; Wang, R.; Deng, D.; Xue, L.; Wang, Q.; Zhang, Y.; Shi, Y.; Xia, X.; Wang, S.; et al. Identification of 9 serum microRNAs as potential noninvasive biomarkers of human astrocytoma. Neuro-oncology 2015, 17, 383-391. [CrossRef]

110. Goze, C.; Reynes, C.; Forestier, L.; Sabatier, R.; Duffau, H. Pilot Study of Whole Blood MicroRNAs as Potential Tools for Diffuse Low-Grade Gliomas Detection. Cell. Mol. Neurobiol. 2018, 38, 715-725. [CrossRef]

111. Yang, C.; Wang, C.; Chen, X.; Chen, S.; Zhang, Y.; Zhi, F.; Wang, J.; Li, L.; Zhou, X.; Li, N.; et al. Identification of seven serum microRNAs from a genome-wide serum microRNA expression profile as potential noninvasive biomarkers for malignant astrocytomas. Int. J. Cancer 2013, 132, 116-127. [CrossRef]

112. Witwer, K.W. Circulating microRNA biomarker studies: Pitfalls and potential solutions. Clin. Chem. 2015, 61, 56-63. [CrossRef]

113. Mo, M.H.; Chen, L.; Fu, Y.; Wang, W.; Fu, S.W. Cell-free Circulating miRNA Biomarkers in Cancer. J. Cancer 2012, 3, 432-448. [CrossRef] 
114. Munagala, R.; Aqil, F.; Gupta, R.C. Exosomal miRNAs as biomarkers of recurrent lung cancer. Tumour Biol. J. Int. Soc. Oncodeve. Biol. Med. 2016, 37, 10703-10714. [CrossRef]

115. Shi, R.; Wang, P.Y.; Li, X.Y.; Chen, J.X.; Li, Y.; Zhang, X.Z.; Zhang, C.G.; Jiang, T.; Li, W.B.; Ding, W.; et al. Exosomal levels of miRNA-21 from cerebrospinal fluids associated with poor prognosis and tumor recurrence of glioma patients. Oncotarget 2015, 6, 26971-26981. [CrossRef]

116. Chiam, K.; Wang, T.; Watson, D.I.; Mayne, G.C.; Irvine, T.S.; Bright, T.; Smith, L.; White, I.A.; Bowen, J.M.; Keefe, D.; et al. Circulating Serum Exosomal miRNAs As Potential Biomarkers for Esophageal Adenocarcinoma. J. Gastrointest. Surg. Off. J. Soc. Surg. Aliment. Tract 2015, 19, 1208-1215. [CrossRef]

117. Warnecke-Eberz, U.; Chon, S.H.; Holscher, A.H.; Drebber, U.; Bollschweiler, E. Exosomal onco-miRs from serum of patients with adenocarcinoma of the esophagus: Comparison of miRNA profiles of exosomes and matching tumor. Tumour Biol. J. Int. Soc. Oncodeve. Biol. Med. 2015, 36, 4643-4653. [CrossRef]

118. Gajos-Michniewicz, A.; Duechler, M.; Czyz, M. MiRNA in melanoma-derived exosomes. Cancer Lett. 2014, 347, 29-37. [CrossRef]

119. Aushev, V.N.; Zborovskaya, I.B.; Laktionov, K.K.; Girard, N.; Cros, M.P.; Herceg, Z.; Krutovskikh, V. Comparisons of microRNA patterns in plasma before and after tumor removal reveal new biomarkers of lung squamous cell carcinoma. PLoS ONE 2013, 8, e78649. [CrossRef]

120. Camacho, L.; Guerrero, P.; Marchetti, D. MicroRNA and protein profiling of brain metastasis competent cell-derived exosomes. PLoS ONE 2013, 8, e73790. [CrossRef]

121. Chugh, P.E.; Sin, S.H.; Ozgur, S.; Henry, D.H.; Menezes, P.; Griffith, J.; Eron, J.J.; Damania, B.; Dittmer, D.P. Systemically circulating viral and tumor-derived microRNAs in KSHV-associated malignancies. PLoS Pathog. 2013, 9, e1003484. [CrossRef]

122. Costa-Silva, B.; Aiello, N.M.; Ocean, A.J.; Singh, S.; Zhang, H.; Thakur, B.K.; Becker, A.; Hoshino, A.; Mark, M.T.; Molina, H.; et al. Pancreatic cancer exosomes initiate pre-metastatic niche formation in the liver. Nat. Cell Biol. 2015, 17, 816-826. [CrossRef]

123. Valentino, A.; Reclusa, P.; Sirera, R.; Giallombardo, M.; Camps, C.; Pauwels, P.; Crispi, S.; Rolfo, C. Exosomal microRNAs in liquid biopsies: Future biomarkers for prostate cancer. Clin. Transl. Oncol. Off. Publ. Fed. Span. Oncol. Soc. Nat. Cancer Inst. Mex. 2017, 19, 651-657. [CrossRef]

124. Fabris, L.; Ceder, Y.; Chinnaiyan, A.M.; Jenster, G.W.; Sorensen, K.D.; Tomlins, S.; Visakorpi, T.; Calin, G.A. The Potential of MicroRNAs as Prostate Cancer Biomarkers. Eur. Urol. 2016, 70, 312-322. [CrossRef]

125. Meng, Y.; Sun, J.; Wang, X.; Hu, T.; Ma, Y.; Kong, C.; Piao, H.; Yu, T.; Zhang, G. Exosomes: A Promising Avenue for the Diagnosis of Breast Cancer. Technol. Cancer Res. Treat. 2019, 18. [CrossRef]

126. Joyce, D.P.; Kerin, M.J.; Dwyer, R.M. Exosome-encapsulated microRNAs as circulating biomarkers for breast cancer. Int. J. Cancer 2016, 139, 1443-1448. [CrossRef]

127. Nassar, F.J.; Nasr, R.; Talhouk, R. MicroRNAs as biomarkers for early breast cancer diagnosis, prognosis and therapy prediction. Pharmacol. Ther. 2017, 172, 34-49. [CrossRef]

128. Drokow, E.K.; Sun, K.; Ahmed, H.A.W.; Akpabla, G.S.; Song, J.; Shi, M. Circulating microRNA as diagnostic biomarkers for haematological cancers: A systematic review and meta-analysis. Cancer Manag. Res. 2019, 11, 4313-4326. [CrossRef]

129. Liu, Y.; Cheng, Z.; Pang, Y.; Cui, L.; Qian, T.; Quan, L.; Zhao, H.; Shi, J.; Ke, X.; Fu, L. Role of microRNAs, circRNAs and long noncoding RNAs in acute myeloid leukemia. J. Hematol. Oncol. 2019, 12, 51. [CrossRef]

130. Mirzaei, H.; Fathullahzadeh, S.; Khanmohammadi, R.; Darijani, M.; Momeni, F.; Masoudifar, A.; Goodarzi, M.; Mardanshah, O.; Stenvang, J.; Jaafari, M.R.; et al. State of the art in microRNA as diagnostic and therapeutic biomarkers in chronic lymphocytic leukemia. J. Cell. Physiol. 2018, 233, 888-900. [CrossRef]

131. Ciccone, M.; Calin, G.A. MicroRNAs in Chronic Lymphocytic Leukemia: An Old Disease with New Genetic Insights. Microrna 2016, 5, 106-112. [CrossRef]

132. Litwinska, Z.; Machalinski, B. miRNAs in chronic myeloid leukemia: Small molecules, essential function. Leuk Lymphoma 2017, 58, 1297-1305. [CrossRef]

133. Carvalho de Oliveira, J.; Molinari Roberto, G.; Baroni, M.; Bezerra Salomao, K.; Alejandra Pezuk, J.; Sol Brassesco, M. MiRNA Dysregulation in Childhood Hematological Cancer. Int. J. Mol. Sci. 2018, 19, 2688. [CrossRef]

134. Zhuo, X.; Zhou, W.; Li, D.; Chang, A.; Wang, Y.; Wu, Y.; Zhou, Q. Plasma microRNA expression signature involving miR-548q, miR-630 and miR-940 as biomarkers for nasopharyngeal carcinoma detection. Cancer Biomark. 2018, 23, 579-587. [CrossRef] 
135. Liu, X.; Luo, H.N.; Tian, W.D.; Lu, J.; Li, G.; Wang, L.; Zhang, B.; Liang, B.J.; Peng, X.H.; Lin, S.X.; et al. Diagnostic and prognostic value of plasma microRNA deregulation in nasopharyngeal carcinoma. Cancer Biol. Ther. 2013, 14, 1133-1142. [CrossRef]

136. Zheng, X.H.; Cui, C.; Ruan, H.L.; Xue, W.Q.; Zhang, S.D.; Hu, Y.Z.; Zhou, X.X.; Jia, W.H. Plasma microRNA profiling in nasopharyngeal carcinoma patients reveals miR-548q and miR-483-5p as potential biomarkers. Chin. J. Cancer 2014, 33, 330-338. [CrossRef]

137. Wang, L.; Yu, B.; Cen, J.; Peng, X.; Liu, Y.; Zeng, F.; Liu, X. Clinical significance of plasma miR-24 dysregulation in nasopharyngeal carcinoma. Nan Fang Yi Ke Da Xue Xue Bao 2015, 35, 743-747.

138. Zeng, X.; Xiang, J.; Wu, M.; Xiong, W.; Tang, H.; Deng, M.; Li, X.; Liao, Q.; Su, B.; Luo, Z.; et al. Circulating miR-17, miR-20a, miR-29c, and miR-223 combined as non-invasive biomarkers in nasopharyngeal carcinoma. PLoS ONE 2012, 7, e46367. [CrossRef]

139. Plieskatt, J.L.; Rinaldi, G.; Feng, Y.; Levine, P.H.; Easley, S.; Martinez, E.; Hashmi, S.; Sadeghi, N.; Brindley, P.J.; Bethony, J.M.; et al. Methods and matrices: Approaches to identifying miRNAs for nasopharyngeal carcinoma. J. Transl. Med. 2014, 12, 3. [CrossRef]

140. Wen, W.; Mai, S.J.; Lin, H.X.; Zhang, M.Y.; Huang, J.L.; Hua, X.; Lin, C.; Long, Z.Q.; Lu, Z.J.; Sun, X.Q.; et al. Identification of two microRNA signatures in whole blood as novel biomarkers for diagnosis of nasopharyngeal carcinoma. J. Transl. Med. 2019, 17, 186. [CrossRef]

141. Yi, S.J.; Liu, P.; Chen, B.L.; Ou-Yang, L.; Xiong, W.M.; Su, J.P. Circulating miR-31-5p may be a potential diagnostic biomarker in nasopharyngeal carcinoma. Neoplasma 2019. [CrossRef]

142. Wang, H.; Wei, X.; Wu, B.; Su, J.; Tan, W.; Yang, K. Tumor-educated platelet miR-34c-3p and miR-18a-5p as potential liquid biopsy biomarkers for nasopharyngeal carcinoma diagnosis. Cancer Manag. Res. 2019, 11, 3351-3360. [CrossRef]

143. Loosen, S.H.; Lurje, G.; Wiltberger, G.; Vucur, M.; Koch, A.; Kather, J.N.; Paffenholz, P.; Tacke, F.; Ulmer, F.T.; Trautwein, C.; et al. Serum levels of miR-29, miR-122, miR-155 and miR-192 are elevated in patients with cholangiocarcinoma. PLoS ONE 2019, 14, e0210944. [CrossRef]

144. Bernuzzi, F.; Marabita, F.; Lleo, A.; Carbone, M.; Mirolo, M.; Marzioni, M.; Alpini, G.; Alvaro, D.; Boberg, K.M.; Locati, M.; et al. Serum microRNAs as novel biomarkers for primary sclerosing cholangitis and cholangiocarcinoma. Clin. Exp. Immunol. 2016, 185, 61-71. [CrossRef]

145. Wu, X.; Xia, M.; Chen, D.; Wu, F.; Lv, Z.; Zhan, Q.; Jiao, Y.; Wang, W.; Chen, G.; An, F. Profiling of downregulated blood-circulating miR-150-5p as a novel tumor marker for cholangiocarcinoma. Tumour Biol. 2016, 37, 15019-15029. [CrossRef]

146. Wang, L.J.; Zhang, K.L.; Zhang, N.; Ma, X.W.; Yan, S.W.; Cao, D.H.; Shi, S.J. Serum miR-26a as a diagnostic and prognostic biomarker in cholangiocarcinoma. Oncotarget 2015, 6, 18631-18640. [CrossRef]

147. Cheng, Q.; Feng, F.; Zhu, L.; Zheng, Y.; Luo, X.; Liu, C.; Yi, B.; Jiang, X. Circulating miR-106a is a Novel Prognostic and Lymph Node Metastasis Indicator for Cholangiocarcinoma. Sci. Rep. 2015, 5, 16103. [CrossRef]

148. Voigtlander, T.; Gupta, S.K.; Thum, S.; Fendrich, J.; Manns, M.P.; Lankisch, T.O.; Thum, T. MicroRNAs in Serum and Bile of Patients with Primary Sclerosing Cholangitis and/or Cholangiocarcinoma. PLoS ONE 2015, 10, e0139305. [CrossRef]

149. Correa-Gallego, C.; Maddalo, D.; Doussot, A.; Kemeny, N.; Kingham, T.P.; Allen, P.J.; D'Angelica, M.I.; DeMatteo, R.P.; Betel, D.; Klimstra, D.; et al. Circulating Plasma Levels of MicroRNA-21 and MicroRNA-221 Are Potential Diagnostic Markers for Primary Intrahepatic Cholangiocarcinoma. PLoS ONE 2016, 11, e0163699. [CrossRef]

150. Wang, S.; Yin, J.; Li, T.; Yuan, L.; Wang, D.; He, J.; Du, X.; Lu, J. Upregulated circulating miR-150 is associated with the risk of intrahepatic cholangiocarcinoma. Oncol. Rep. 2015, 33, 819-825. [CrossRef]

151. Shigehara, K.; Yokomuro, S.; Ishibashi, O.; Mizuguchi, Y.; Arima, Y.; Kawahigashi, Y.; Kanda, T.; Akagi, I.; Tajiri, T.; Yoshida, H.; et al. Real-Time PCR-Based Analysis of the Human Bile MicroRNAome Identifies miR-9 as a Potential Diagnostic Biomarker for Biliary Tract Cancer. PLoS ONE 2011, 6, e23584. [CrossRef]

152. Kojima, M.; Sudo, H.; Kawauchi, J.; Takizawa, S.; Kondou, S.; Nobumasa, H.; Ochiai, A. MicroRNA markers for the diagnosis of pancreatic and biliary-tract cancers. PLoS ONE 2015, 10, e0118220. [CrossRef] 
153. Baraniskin, A.; Nopel-Dunnebacke, S.; Schumacher, B.; Gerges, C.; Bracht, T.; Sitek, B.; Meyer, H.E.; Gerken, G.; Dechene, A.; Schlaak, J.F.; et al. Analysis of U2 small nuclear RNA fragments in the bile differentiates cholangiocarcinoma from primary sclerosing cholangitis and other benign biliary disorders. Dig. Dis. Sci. 2014, 59, 1436-1441. [CrossRef]

154. Li, G.; Pu, Y. MicroRNA signatures in total peripheral blood of gallbladder cancer patients. Tumour Biol. 2015, 36, 6985-6990. [CrossRef]

155. Kitagawa, T.; Taniuchi, K.; Tsuboi, M.; Sakaguchi, M.; Kohsaki, T.; Okabayashi, T.; Saibara, T. Circulating pancreatic cancer exosomal RNAs for detection of pancreatic cancer. Mol. Oncol. 2019, 13, 212-227. [CrossRef]

156. Baraniskin, A.; Nopel-Dunnebacke, S.; Ahrens, M.; Jensen, S.G.; Zollner, H.; Maghnouj, A.; Wos, A.; Mayerle, J.; Munding, J.; Kost, D.; et al. Circulating U2 small nuclear RNA fragments as a novel diagnostic biomarker for pancreatic and colorectal adenocarcinoma. Int. J. Cancer 2013, 132, E48-E57. [CrossRef]

157. Cui, L.; Lou, Y.; Zhang, X.; Zhou, H.; Deng, H.; Song, H.; Yu, X.; Xiao, B.; Wang, W.; Guo, J. Detection of circulating tumor cells in peripheral blood from patients with gastric cancer using piRNAs as markers. Clin. Biochem. 2011, 44, 1050-1057. [CrossRef]

158. Yu, B.; Du, Q.; Li, H.; Liu, H.Y.; Ye, X.; Zhu, B.; Zhai, Q.; Li, X.X. Diagnostic potential of serum exosomal colorectal neoplasia differentially expressed long non-coding RNA (CRNDE-p) and microRNA-217 expression in colorectal carcinoma. Oncotarget 2017, 8, 83745-83753. [CrossRef]

159. Vychytilova-Faltejskova, P.; Stitkovcova, K.; Radova, L.; Sachlova, M.; Kosarova, Z.; Slaba, K.; Kala, Z.; Svoboda, M.; Kiss, I.; Vyzula, R.; et al. Circulating PIWI-Interacting RNAs piR-5937 and piR-28876 Are Promising Diagnostic Biomarkers of Colon Cancer. Cancer Epidemiol. Biomark. Prev. Publ. Am. Assoc. Cancer Res. Cosponsored Am. Soc. Pre. Oncol. 2018, 27, 1019-1028. [CrossRef]

160. Qu, A.; Wang, W.; Yang, Y.; Zhang, X.; Dong, Y.; Zheng, G.; Wu, Q.; Zou, M.; Du, L.; Wang, Y.; et al. A serum piRNA signature as promising non-invasive diagnostic and prognostic biomarkers for colorectal cancer. Cancer Manag. Res. 2019, 11, 3703-3720. [CrossRef]

161. Liao, J.; Yu, L.; Mei, Y.; Guarnera, M.; Shen, J.; Li, R.; Liu, Z.; Jiang, F. Small nucleolar RNA signatures as biomarkers for non-small-cell lung cancer. Mol. Cancer 2010, 9, 198. [CrossRef]

162. Su, J.; Liao, J.; Gao, L.; Shen, J.; Guarnera, M.A.; Zhan, M.; Fang, H.; Stass, S.A.; Jiang, F. Analysis of small nucleolar RNAs in sputum for lung cancer diagnosis. Oncotarget 2016, 7, 5131-5142. [CrossRef]

163. Kohler, J.; Schuler, M.; Gauler, T.C.; Nopel-Dunnebacke, S.; Ahrens, M.; Hoffmann, A.C.; Kasper, S.; Nensa, F.; Gomez, B.; Hahnemann, M.; et al. Circulating U2 small nuclear RNA fragments as a diagnostic and prognostic biomarker in lung cancer patients. J. Cancer Res. Clin. Oncol. 2016, 142, 795-805. [CrossRef]

164. Mazieres, J.; Catherinne, C.; Delfour, O.; Gouin, S.; Rouquette, I.; Delisle, M.B.; Prevot, G.; Escamilla, R.; Didier, A.; Persing, D.H.; et al. Alternative processing of the U2 small nuclear RNA produces a 19-22nt fragment with relevance for the detection of non-small cell lung cancer in human serum. PLoS ONE 2013,8, e60134. [CrossRef]

165. Arantes, L.; De Carvalho, A.C.; Melendez, M.E.; Lopes Carvalho, A. Serum, plasma and saliva biomarkers for head and neck cancer. Expert Rev. Mol. Diagn. 2018, 18, 85-112. [CrossRef]

166. Wang, J.L.; Wang, X.; Yang, D.; Shi, W.J. The Expression of MicroRNA-155 in Plasma and Tissue Is Matched in Human Laryngeal Squamous Cell Carcinoma. Yonsei Med. J. 2016, 57, 298-305. [CrossRef]

167. Ayaz, L.; Gorur, A.; Yaroglu, H.Y.; Ozcan, C.; Tamer, L. Differential expression of microRNAs in plasma of patients with laryngeal squamous cell carcinoma: Potential early-detection markers for laryngeal squamous cell carcinoma. J. Cancer Res. Clin. Oncol. 2013, 139, 1499-1506. [CrossRef]

168. Lucas Grzelczyk, W.; Szemraj, J.; Kwiatkowska, S.; Jozefowicz-Korczynska, M. Serum expression of selected miRNAs in patients with laryngeal squamous cell carcinoma (LSCC). Diagn. Pathol. 2019, 14, 49. [CrossRef]

169. Zhou, E.; Luo, L.; Ma, L.J.; Yin, J.; Tan, Z.Q.; Miao, G.Y.; Liu, J.; Xiao, X.P. Diagnostic value of serum miRNA let-7a for laryngeal carcinoma and effects of let-7a on proliferation and apoptosis of laryngeal carcinoma cells. Zhonghua Er Bi Yan Hou Tou Jing Wai Ke Za Zhi 2019, 54, 534-539. [CrossRef]

170. Xu, Y.; Lin, Y.P.; Yang, D.; Zhang, G.; Zhou, H.F. Expression of serum microRNA-378 and its clinical significance in laryngeal squamous cell carcinoma. Eur. Rev. Med. Pharmacol. Sci. 2016, 20, 5137-5142.

171. Yilmaz, S.S.; Guzel, E.; Karatas, O.F.; Yilmaz, M.; Creighton, C.J.; Ozen, M. MiR-221 as a pre- and postoperative plasma biomarker for larynx cancer patients. Laryngoscope 2015, 125, E377-E381. [CrossRef] 
172. Iliev, R.; Fedorko, M.; Machackova, T.; Mlcochova, H.; Svoboda, M.; Pacik, D.; Dolezel, J.; Stanik, M.; Slaby, O. Expression Levels of PIWI-interacting RNA, piR-823, Are Deregulated in Tumor Tissue, Blood Serum and Urine of Patients with Renal Cell Carcinoma. Anticancer Res. 2016, 36, 6419-6423. [CrossRef]

173. Eissa, S.; Safwat, M.; Matboli, M.; Zaghloul, A.; El-Sawalhi, M.; Shaheen, A. Measurement of Urinary Level of a Specific Competing endogenous RNA network (FOS and RCAN mRNA/miR-324-5p, miR-4738-3p,/lncRNA miR-497-HG) Enables Diagnosis of Bladder Cancer. Urol. Oncol. 2019, 37, 292.e219-292.e227. [CrossRef]

174. Appaiah, H.N.; Goswami, C.P.; Mina, L.A.; Badve, S.; Sledge, G.W., Jr.; Liu, Y.; Nakshatri, H. Persistent upregulation of U6:SNORD44 small RNA ratio in the serum of breast cancer patients. Breast Cancer Res. BCR 2011, 13, R86. [CrossRef]

175. Kuhlmann, J.D.; Baraniskin, A.; Hahn, S.A.; Mosel, F.; Bredemeier, M.; Wimberger, P.; Kimmig, R.; Kasimir-Bauer, S. Circulating U2 small nuclear RNA fragments as a novel diagnostic tool for patients with epithelial ovarian cancer. Clin. Chem. 2014, 60, 206-213. [CrossRef]

176. Muinelo-Romay, L.; Casas-Arozamena, C.; Abal, M. Liquid Biopsy in Endometrial Cancer: New Opportunities for Personalized Oncology. Int. J. Mol. Sci. 2018, 19, 2311. [CrossRef]

177. Torres, A.; Torres, K.; Pesci, A.; Ceccaroni, M.; Paszkowski, T.; Cassandrini, P.; Zamboni, G.; Maciejewski, R. Diagnostic and prognostic significance of miRNA signatures in tissues and plasma of endometrioid endometrial carcinoma patients. Int. J. Cancer 2013, 132, 1633-1645. [CrossRef]

178. Montagnana, M.; Benati, M.; Danese, E.; Giudici, S.; Perfranceschi, M.; Ruzzenenete, O.; Salvagno, G.L.; Bassi, A.; Gelati, M.; Paviati, E.; et al. Aberrant MicroRNA Expression in Patients With Endometrial Cancer. Int. J. Gynecol. Cancer 2017, 27, 459-466. [CrossRef]

179. Jia, W.; Wu, Y.; Zhang, Q.; Gao, G.; Zhang, C.; Xiang, Y. Identification of four serum microRNAs from a genome-wide serum microRNA expression profile as potential non-invasive biomarkers for endometrioid endometrial cancer. Oncol. Lett. 2013, 6, 261-267. [CrossRef]

180. Benati, M.; Montagnana, M.; Danese, E.; Paviati, E.; Giudici, S.; Franchi, M.; Lippi, G. Evaluation of mir-203 Expression Levels and DNA Promoter Methylation Status in Serum of Patients with Endometrial Cancer. Clin. Lab. 2017, 63, 1675-1681. [CrossRef]

181. Gao, Y.; Dai, M.; Liu, H.; He, W.; Lin, S.; Yuan, T.; Chen, H.; Dai, S. Diagnostic value of circulating miR-21: An update meta-analysis in various cancers and validation in endometrial cancer. Oncotarget 2016, 7, 68894-68908. [CrossRef]

182. Jiang, Y.; Wang, N.; Yin, D.; Li, Y.K.; Guo, L.; Shi, L.P.; Huang, X. Changes in the Expression of Serum MiR-887-5p in Patients With Endometrial Cancer. Int. J. Gynecol. Cancer 2016, 26, 1143-1147. [CrossRef]

183. Srivastava, A.; Moxley, K.; Ruskin, R.; Dhanasekaran, D.N.; Zhao, Y.D.; Ramesh, R. A Non-invasive Liquid Biopsy Screening of Urine-Derived Exosomes for miRNAs as Biomarkers in Endometrial Cancer Patients. AAPS J. 2018, 20, 82. [CrossRef]

184. Nahand, J.S.; Taghizadeh-Boroujeni, S.; Karimzadeh, M.; Borran, S.; Pourhanifeh, M.H.; Moghoofei, M.; Bokharaei-Salim, F.; Karampoor, S.; Jafari, A.; Asemi, Z.; et al. microRNAs: New prognostic, diagnostic, and therapeutic biomarkers in cervical cancer. J. Cell. Physiol. 2019, 234, 17064-17099. [CrossRef]

185. Okoye, J.O.; Ngokere, A.A.; Onyenekwe, C.C.; Erinle, C.A. Comparable expression of miR-let-7b, miR-21, miR-182, miR-145, and p53 in serum and cervical cells: Diagnostic implications for early detection of cervical lesions. Int. J. Health Sci. (Qassim) 2019, 13, 29-38.

186. Xin, F.; Liu, P.; Ma, C.F. A circulating serum miRNA panel as early detection biomarkers of cervical intraepithelial neoplasia. Eur. Rev. Med. Pharmacol. Sci. 2016, 20, 4846-4851.

187. Jia, W.; Wu, Y.; Zhang, Q.; Gao, G.E.; Zhang, C.; Xiang, Y. Expression profile of circulating microRNAs as a promising fingerprint for cervical cancer diagnosis and monitoring. Mol. Clin. Oncol. 2015, 3, 851-858. [CrossRef]

188. Kong, Q.; Tang, Z.; Xiang, F.; Jiang, J.; Yue, H.; Wu, R.; Kang, X. Diagnostic Value of Serum hsa-mir-92a in Patients with Cervical Cancer. Clin. Lab. 2017, 63, 335-340. [CrossRef]

189. Wang, W.T.; Zhao, Y.N.; Yan, J.X.; Weng, M.Y.; Wang, Y.; Chen, Y.Q.; Hong, S.J. Differentially expressed microRNAs in the serum of cervical squamous cell carcinoma patients before and after surgery. J. Hematol. Oncol. 2014, 7, 6. [CrossRef]

190. Ma, Q.; Wan, G.; Wang, S.; Yang, W.; Zhang, J.; Yao, X. Serum microRNA-205 as a novel biomarker for cervical cancer patients. Cancer Cell Int. 2014, 14, 81. [CrossRef] 
191. Khare, D.; Goldschmidt, N.; Bardugo, A.; Gur-Wahnon, D.; Ben-Dov, I.Z.; Avni, B. Plasma microRNA profiling: Exploring better biomarkers for lymphoma surveillance. PLoS ONE 2017, 12, e0187722. [CrossRef]

192. Cordeiro, A.; Navarro, A.; Gaya, A.; Diaz-Beya, M.; Gonzalez-Farre, B.; Castellano, J.J.; Fuster, D.; Martinez, C.; Martinez, A.; Monzo, M. PiwiRNA-651 as marker of treatment response and survival in classical Hodgkin lymphoma. Oncotarget 2016, 7, 46002-46013. [CrossRef]

193. Lopez-Santillan, M.; Larrabeiti-Etxebarria, A.; Arzuaga-Mendez, J.; Lopez-Lopez, E.; Garcia-Orad, A. Circulating miRNAs as biomarkers in diffuse large B-cell lymphoma: A systematic review. Oncotarget 2018, 9, 22850-22861. [CrossRef]

194. Drusco, A.; Bottoni, A.; Lagana, A.; Acunzo, M.; Fassan, M.; Cascione, L.; Antenucci, A.; Kumchala, P.; Vicentini, C.; Gardiman, M.P.; et al. A differentially expressed set of microRNAs in cerebro-spinal fluid (CSF) can diagnose CNS malignancies. Oncotarget 2015, 6, 20829-20839. [CrossRef]

195. Jurkovicova, D.; Lukackova, R.; Magyerkova, M.; Kulcsar, L.; Krivjanska, M.; Krivjansky, V.; Chovanec, M. microRNA expression profiling as supportive diagnostic and therapy prediction tool in chronic myeloid leukemia. Neoplasma 2015, 62, 949-958. [CrossRef]

196. Zhang, J.; Jiang, Y.; Han, X.; Roy, M.; Liu, W.; Zhao, X.; Liu, J. Differential expression profiles and functional analysis of plasma miRNAs associated with chronic myeloid leukemia phases. Future Oncol. 2019, 15, 763-776. [CrossRef]

197. Fallah, P.; Amirizadeh, N.; Poopak, B.; Toogeh, G.; Arefian, E.; Kohram, F.; Hosseini Rad, S.M.; Kohram, M.; Teimori Naghadeh, H.; Soleimani, M. Expression pattern of key microRNAs in patients with newly diagnosed chronic myeloid leukemia in chronic phase. Int. J. Lab. Hematol. 2015, 37, 560-568. [CrossRef]

198. Rashed, W.M.; Hammad, A.M.; Saad, A.M.; Shohdy, K.S. MicroRNA as a diagnostic biomarker in childhood acute lymphoblastic leukemia; systematic review, meta-analysis and recommendations. Crit. Rev. Oncol. Hematol. 2019, 136, 70-78. [CrossRef]

199. Zhou, P.; Li, X. Serum miR-338-5p has potential for use as a tumor marker for retinoblastoma. Oncol. Lett. 2019, 18, 307-313. [CrossRef]

200. Chen, Y.Z.; Liu, Z.P.; Zhou, K.Y.; Li, B. Value of serum miR-17-92 cluster in diagnosis of retinoblastoma. Zhongguo Dang Dai Er Ke Za Zhi 2017, 19, 776-780.

201. Beta, M.; Venkatesan, N.; Vasudevan, M.; Vetrivel, U.; Khetan, V.; Krishnakumar, S. Identification and Insilico Analysis of Retinoblastoma Serum microRNA Profile and Gene Targets Towards Prediction of Novel Serum Biomarkers. Bioinform. Biol. Insights 2013, 7, 21-34. [CrossRef]

202. Liu, S.S.; Wang, Y.S.; Sun, Y.F.; Miao, L.X.; Wang, J.; Li, Y.S.; Liu, H.Y.; Liu, Q.L. Plasma microRNA-320, microRNA-let-7e and microRNA-21 as novel potential biomarkers for the detection of retinoblastoma. Biomed. Rep. 2014, 2, 424-428. [CrossRef]

203. Li, M.; Song, Q.; Li, H.; Lou, Y.; Wang, L. Circulating miR-25-3p and miR-451a May Be Potential Biomarkers for the Diagnosis of Papillary Thyroid Carcinoma. PLoS ONE 2015, 10, e0132403. [CrossRef]

204. Wang, Z.; Lv, J.; Zou, X.; Huang, Z.; Zhang, H.; Liu, Q.; Jiang, L.; Zhou, X.; Zhu, W. A three plasma microRNA signature for papillary thyroid carcinoma diagnosis in Chinese patients. Gene 2019, 693, 37-45. [CrossRef]

205. Yu, S.; Liu, X.; Zhang, Y.; Li, J.; Chen, S.; Zheng, H.; Reng, R.; Zhang, C.; Chen, J.; Chen, L. Circulating microRNA124-3p, microRNA9-3p and microRNA196b-5p may be potential signatures for differential diagnosis of thyroid nodules. Oncotarget 2016, 7, 84165-84177. [CrossRef]

206. Lee, Y.S.; Lim, Y.S.; Lee, J.C.; Wang, S.G.; Park, H.Y.; Kim, S.Y.; Lee, B.J. Differential expression levels of plasma-derived miR-146b and miR-155 in papillary thyroid cancer. Oral Oncol. 2015, 51, 77-83. [CrossRef]

207. Lee, J.C.; Zhao, J.T.; Clifton-Bligh, R.J.; Gill, A.; Gundara, J.S.; Ip, J.C.; Glover, A.; Sywak, M.S.; Delbridge, L.W.; Robinson, B.G.; et al. MicroRNA-222 and microRNA-146b are tissue and circulating biomarkers of recurrent papillary thyroid cancer. Cancer 2013, 119, 4358-4365. [CrossRef]

208. Shabani, N.; Sheikholeslami, S.; Paryan, M.; Zarif Yeganeh, M.; Tavangar, S.M.; Azizi, F.; Mohammadi-Yeganeh, S.; Hedayati, M. An investigation on the expression of miRNAs including miR-144 and miR-34a in plasma samples of RET-positive and RET-negative medullar thyroid carcinoma patients. J. Cell. Physiol. 2019. [CrossRef]

209. Zhang, Y.; Pan, J.; Xu, D.; Yang, Z.; Sun, J.; Sun, L.; Wu, Y.; Qiao, H. Combination of serum microRNAs and ultrasound profile as predictive biomarkers of diagnosis and prognosis for papillary thyroid microcarcinoma. Oncol. Rep. 2018, 40, 3611-3624. [CrossRef] 
210. Pilli, T.; Cantara, S.; Marzocchi, C.; Cardinale, S.; Santini, C.; Cevenini, G.; Pacini, F. Diagnostic Value of Circulating microRNA-95 and -190 in the Differential Diagnosis of Thyroid Nodules: A Validation Study in 1000 Consecutive Patients. Thyroid 2017, 27, 1053-1057. [CrossRef]

211. Zhang, Y.; Xu, D.; Pan, J.; Yang, Z.; Chen, M.; Han, J.; Zhang, S.; Sun, L.; Qiao, H. Dynamic monitoring of circulating microRNAs as a predictive biomarker for the diagnosis and recurrence of papillary thyroid carcinoma. Oncol. Lett. 2017, 13, 4252-4266. [CrossRef]

212. Igci, Y.Z.; Ozkaya, M.; Korkmaz, H.; Bozgeyik, E.; Bayraktar, R.; Ulasli, M.; Erkilic, S.; Eraydin, A.; Oztuzcu, S. Expression Levels of miR-30a-5p in Papillary Thyroid Carcinoma: A Comparison Between Serum and Fine Needle Aspiration Biopsy Samples. Genet. Test. Mol. Biomark. 2015, 19, 418-423. [CrossRef]

213. Graham, M.E.; Hart, R.D.; Douglas, S.; Makki, F.M.; Pinto, D.; Butler, A.L.; Bullock, M.; Rigby, M.H.; Trites, J.R.; Taylor, S.M.; et al. Serum microRNA profiling to distinguish papillary thyroid cancer from benign thyroid masses. J. Otolaryngol. Head Neck Surg. 2015, 44, 33. [CrossRef]

214. Cantara, S.; Pilli, T.; Sebastiani, G.; Cevenini, G.; Busonero, G.; Cardinale, S.; Dotta, F.; Pacini, F. Circulating miRNA95 and miRNA190 are sensitive markers for the differential diagnosis of thyroid nodules in a Caucasian population. J. Clin. Endocrinol. Metab. 2014, 99, 4190-4198. [CrossRef]

215. Yoruker, E.E.; Terzioglu, D.; Teksoz, S.; Uslu, F.E.; Gezer, U.; Dalay, N. MicroRNA Expression Profiles in Papillary Thyroid Carcinoma, Benign Thyroid Nodules and Healthy Controls. J. Cancer 2016, 7, 803-809. [CrossRef]

216. Yu, S.; Liu, Y.; Wang, J.; Guo, Z.; Zhang, Q.; Yu, F.; Zhang, Y.; Huang, K.; Li, Y.; Song, E.; et al. Circulating microRNA profiles as potential biomarkers for diagnosis of papillary thyroid carcinoma. J. Clin. Endocrinol. Metab. 2012, 97, 2084-2092. [CrossRef]

217. Mahmoudian-Sani, M.R.; Mehri-Ghahfarrokhi, A.; Asadi-Samani, M.; Mobini, G.R. Serum miRNAs as Biomarkers for the Diagnosis and Prognosis of Thyroid Cancer: A Comprehensive Review of the Literature. Eur. Thyroid J. 2017, 6, 171-177. [CrossRef]

218. Samsonov, R.; Burdakov, V.; Shtam, T.; Radzhabova, Z.; Vasilyev, D.; Tsyrlina, E.; Titov, S.; Ivanov, M.; Berstein, L.; Filatov, M.; et al. Plasma exosomal miR-21 and miR-181a differentiates follicular from papillary thyroid cancer. Tumour Biol. 2016, 37, 12011-12021. [CrossRef]

219. Huang, C.; Wang, Q.; Ma, S.; Sun, Y.; Vadamootoo, A.S.; Jin, C. A four serum-miRNA panel serves as a potential diagnostic biomarker of osteosarcoma. Int. J. Clin. Oncol. 2019, 24, 976-982. [CrossRef]

220. Fujiwara, T.; Uotani, K.; Yoshida, A.; Morita, T.; Nezu, Y.; Kobayashi, E.; Yoshida, A.; Uehara, T.; Omori, T.; Sugiu, K.; et al. Clinical significance of circulating miR-25-3p as a novel diagnostic and prognostic biomarker in osteosarcoma. Oncotarget 2017, 8, 33375-33392. [CrossRef]

221. Monterde-Cruz, L.; Ramirez-Salazar, E.G.; Rico-Martinez, G.; Linares-Gonzalez, L.M.; Guzman-Gonzalez, R.; Delgado-Cedillo, E.; Estrada-Villasenor, E.; Valdes-Flores, M.; Velazquez-Cruz, R.; Hidalgo-Bravo, A. Circulating miR-215-5p and miR-642a-5p as potential biomarker for diagnosis of osteosarcoma in Mexican population. Hum. Cell 2018, 31, 292-299. [CrossRef]

222. Yao, Z.S.; Li, C.; Liang, D.; Jiang, X.B.; Tang, J.J.; Ye, L.Q.; Yuan, K.; Ren, H.; Yang, Z.D.; Jin, D.X.; et al. Diagnostic and prognostic implications of serum miR-101 in osteosarcoma. Cancer Biomark. Sect. A Dis. Markers 2018, 22, 127-133. [CrossRef]

223. Cong, C.; Wang, W.; Tian, J.; Gao, T.; Zheng, W.; Zhou, C. Identification of serum miR-124 as a biomarker for diagnosis and prognosis in osteosarcoma. Cancer Biomark. 2018, 21, 449-454. [CrossRef]

224. Liu, W.; Zhao, X.; Zhang, Y.J.; Fang, G.W.; Xue, Y. MicroRNA-375 as a potential serum biomarker for the diagnosis, prognosis, and chemosensitivity prediction of osteosarcoma. J. Int. Med. Res. 2018, 46, 975-983. [CrossRef]

225. Liu, K.; Sun, X.; Zhang, Y.; Liu, L.; Yuan, Q. MiR-598: A tumor suppressor with biomarker significance in osteosarcoma. Life Sci. 2017, 188, 141-148. [CrossRef]

226. Niu, J.; Sun, Y.; Guo, Q.; Niu, D.; Liu, B. Serum miR-95-3p is a diagnostic and prognostic marker for osteosarcoma. Springerplus 2016, 5, 1947. [CrossRef]

227. Liu, J.D.; Xin, Q.; Tao, C.S.; Sun, P.F.; Xu, P.; Wu, B.; Qu, L.; Li, S.Z. Serum miR-300 as a diagnostic and prognostic biomarker in osteosarcoma. Oncol. Lett. 2016, 12, 3912-3918. [CrossRef]

228. Pang, P.C.; Shi, X.Y.; Huang, W.L.; Sun, K. miR-497 as a potential serum biomarker for the diagnosis and prognosis of osteosarcoma. Eur. Rev. Med. Pharmacol. Sci. 2016, 20, 3765-3769. 
229. Cao, L.; Wang, J.; Wang, P.Q. MiR-326 is a diagnostic biomarker and regulates cell survival and apoptosis by targeting Bcl-2 in osteosarcoma. Biomed. Pharmacother. 2016, 84, 828-835. [CrossRef]

230. Dong, J.; Liu, Y.; Liao, W.; Liu, R.; Shi, P.; Wang, L. miRNA-223 is a potential diagnostic and prognostic marker for osteosarcoma. J. Bone Oncol. 2016, 5, 74-79. [CrossRef]

231. Zhou, S.; Wang, B.; Hu, J.; Zhou, Y.; Jiang, M.; Wu, M.; Qin, L.; Yang, X. miR-421 is a diagnostic and prognostic marker in patients with osteosarcoma. Tumour Biol. 2016, 37, 9001-9007. [CrossRef]

232. Li, H.; Zhang, K.; Liu, L.H.; Ouyang, Y.; Guo, H.B.; Zhang, H.; Bu, J.; Xiao, T. MicroRNA screening identifies circulating microRNAs as potential biomarkers for osteosarcoma. Oncol. Lett. 2015, 10, 1662-1668. [CrossRef]

233. Wang, N.G.; Wang, D.C.; Tan, B.Y.; Wang, F.; Yuan, Z.N. Down-regulation of microRNA152 is associated with the diagnosis and prognosis of patients with osteosarcoma. Int. J. Clin. Exp. Pathol. 2015, 8, 9314-9319.

234. Wang, T.; Ji, F.; Dai, Z.; Xie, Y.; Yuan, D. Increased expression of microRNA-191 as a potential serum biomarker for diagnosis and prognosis in human osteosarcoma. Cancer Biomark. 2015, 15, 543-550. [CrossRef]

235. Yang, Z.; Zhang, Y.; Zhang, X.; Zhang, M.; Liu, H.; Zhang, S.; Qi, B.; Sun, X. Serum microRNA-221 functions as a potential diagnostic and prognostic marker for patients with osteosarcoma. Biomed. Pharmacother. 2015, 75, 153-158. [CrossRef]

236. Zhou, G.; Lu, M.; Chen, J.; Li, C.; Zhang, J.; Chen, J.; Shi, X.; Wu, S. Identification of miR-199a-5p in serum as noninvasive biomarkers for detecting and monitoring osteosarcoma. Tumour Biol. 2015, 36, 8845-8852. [CrossRef]

237. Tang, J.; Zhao, H.; Cai, H.; Wu, H. Diagnostic and prognostic potentials of microRNA-27a in osteosarcoma. Biomed. Pharmacother. 2015, 71, 222-226. [CrossRef]

238. Cai, H.; Zhao, H.; Tang, J.; Wu, H. Serum miR-195 is a diagnostic and prognostic marker for osteosarcoma. J. Surg. Res. 2015, 194, 505-510. [CrossRef]

239. Zhang, C.; Yao, C.; Li, H.; Wang, G.; He, X. Serum levels of microRNA-133b and microRNA-206 expression predict prognosis in patients with osteosarcoma. Int. J. Clin. Exp. Pathol. 2014, 7, 4194-4203.

240. Hong, Q.; Fang, J.; Pang, Y.; Zheng, J. Prognostic value of the microRNA-29 family in patients with primary osteosarcomas. Med. Oncol. 2014, 31, 37. [CrossRef]

241. Huang, C.; Sun, Y.; Ma, S.; Vadamootoo, A.S.; Wang, L.; Jin, C. Identification of circulating miR-663a as a potential biomarker for diagnosing osteosarcoma. Pathol. Res. Pract. 2019, 215, 152411. [CrossRef]

242. Lian, F.; Cui, Y.; Zhou, C.; Gao, K.; Wu, L. Identification of a plasma four-microRNA panel as potential noninvasive biomarker for osteosarcoma. PLoS ONE 2015, 10, e0121499. [CrossRef]

243. Zhou, L.; Ma, X.; Yue, J.; Chen, T.; Wang, X.Y.; Wang, Z.W.; Pan, J.; Lin, Y. The diagnostic effect of serum miR-139-5p as an indicator in osteosarcoma. Cancer Biomark. 2018, 23, 561-567. [CrossRef]

244. Hua, J.; Liu, D.; Cao, L.; Wang, D.; Wu, T.; Lin, F.; Su, P.; Niu, Y.; Sun, Y. Diagnostic and prognostic values of blood microRNA-Let7A for osteosarcoma. J. Bone Oncol. 2018, 12, 65-68. [CrossRef]

245. Ma, W.; Zhang, X.; Chai, J.; Chen, P.; Ren, P.; Gong, M. Circulating miR-148a is a significant diagnostic and prognostic biomarker for patients with osteosarcoma. Tumour Biol. 2014, 35, 12467-12472. [CrossRef]

246. Polini, B.; Carpi, S.; Romanini, A.; Breschi, M.C.; Nieri, P.; Podesta, A. Circulating cell-free microRNAs in cutaneous melanoma staging and recurrence or survival prognosis. Pigment Cell Melanoma Res. 2019, 32, 486-499. [CrossRef]

247. Mumford, S.L.; Towler, B.P.; Pashler, A.L.; Gilleard, O.; Martin, Y.; Newbury, S.F. Circulating MicroRNA Biomarkers in Melanoma: Tools and Challenges in Personalised Medicine. Biomolecules 2018, 8, 21. [CrossRef]

248. Margue, C.; Reinsbach, S.; Philippidou, D.; Beaume, N.; Walters, C.; Schneider, J.G.; Nashan, D.; Behrmann, I.; Kreis, S. Comparison of a healthy miRNome with melanoma patient miRNomes: Are microRNAs suitable serum biomarkers for cancer? Oncotarget 2015, 6, 12110-12127. [CrossRef]

249. Van Laar, R.; Lincoln, M.; Van Laar, B. Development and validation of a plasma-based melanoma biomarker suitable for clinical use. Br. J. Cancer 2018, 118, 857-866. [CrossRef]

250. Sole, C.; Tramonti, D.; Schramm, M.; Goicoechea, I.; Armesto, M.; Hernandez, L.I.; Manterola, L.; Fernandez-Mercado, M.; Mujika, K.; Tuneu, A.; et al. The Circulating Transcriptome as a Source of Biomarkers for Melanoma. Cancers (Basel) 2019, 11, 70. [CrossRef]

251. Siomi, M.C.; Sato, K.; Pezic, D.; Aravin, A.A. PIWI-interacting small RNAs: The vanguard of genome defence. Nat. Rev. Mol. Cell Biol. 2011, 12, 246-258. [CrossRef]

252. Ozata, D.M.; Gainetdinov, I.; Zoch, A.; O'Carroll, D.; Zamore, P.D. PIWI-interacting RNAs: Small RNAs with big functions. Nat. Rev. Genet. 2019, 20, 89-108. [CrossRef] 
253. Girard, A.; Sachidanandam, R.; Hannon, G.J.; Carmell, M.A. A germline-specific class of small RNAs binds mammalian Piwi proteins. Nature 2006, 442, 199-202. [CrossRef]

254. Romano, G.; Veneziano, D.; Acunzo, M.; Croce, C.M. Small non-coding RNA and cancer. Carcinogenesis 2017, 38, 485-491. [CrossRef]

255. Tosar, J.P.; Rovira, C.; Cayota, A. Non-coding RNA fragments account for the majority of annotated piRNAs expressed in somatic non-gonadal tissues. Commun. Biol. 2018, 1, 2. [CrossRef]

256. Halic, M.; Moazed, D. Transposon silencing by piRNAs. Cell 2009, 138, 1058-1060. [CrossRef]

257. Weick, E.M.; Miska, E.A. piRNAs: From biogenesis to function. Development 2014, 141, 3458-3471. [CrossRef]

258. Weng, W.; Li, H.; Goel, A. Piwi-interacting RNAs (piRNAs) and cancer: Emerging biological concepts and potential clinical implications. Biochim. Biophys. Acta Rev. Cancer 2019, 1871, 160-169. [CrossRef]

259. Ha, H.; Song, J.; Wang, S.; Kapusta, A.; Feschotte, C.; Chen, K.C.; Xing, J. A comprehensive analysis of piRNAs from adult human testis and their relationship with genes and mobile elements. BMC Genom. 2014, 15, 545. [CrossRef]

260. Bahn, J.H.; Zhang, Q.; Li, F.; Chan, T.M.; Lin, X.; Kim, Y.; Wong, D.T.; Xiao, X. The landscape of microRNA, Piwi-interacting RNA, and circular RNA in human saliva. Clin. Chem. 2015, 61, 221-230. [CrossRef]

261. Slaby, O. Non-coding RNAs as Biomarkers for Colorectal Cancer Screening and Early Detection. Adv. Exp. Med. Biol. 2016, 937, 153-170. [CrossRef]

262. Kiss, T. Small nucleolar RNAs: An abundant group of noncoding RNAs with diverse cellular functions. Cell 2002, 109, 145-148. [CrossRef]

263. Klinge, S.; Woolford, J.L. Ribosome assembly coming into focus. Nat. Rev. Mol. Cell Biol. 2019, $20,116-131$. [CrossRef]

264. Bohnsack, M.T.; Sloan, K.E. Modifications in small nuclear RNAs and their roles in spliceosome assembly and function. Biol. Chem. 2018, 399, 1265-1276. [CrossRef]

265. Dieci, G.; Preti, M.; Montanini, B. Eukaryotic snoRNAs: A paradigm for gene expression flexibility. Genomics 2009, 94, 83-88. [CrossRef]

266. Liang, J.; Wen, J.; Huang, Z.; Chen, X.P.; Zhang, B.X.; Chu, L. Small Nucleolar RNAs: Insight Into Their Function in Cancer. Front. Oncol. 2019, 9, 587. [CrossRef]

267. Scott, M.S.; Ono, M. From snoRNA to miRNA: Dual function regulatory non-coding RNAs. Biochimie 2011, 93, 1987-1992. [CrossRef]

268. Yamamura, S.; Imai-Sumida, M.; Tanaka, Y.; Dahiya, R. Interaction and cross-talk between non-coding RNAs. Cell. Mol. Life Sci. 2018, 75, 467-484. [CrossRef]

269. Ender, C.; Krek, A.; Friedlander, M.R.; Beitzinger, M.; Weinmann, L.; Chen, W.; Pfeffer, S.; Rajewsky, N.; Meister, G. A human snoRNA with microRNA-like functions. Mol. Cell 2008, 32, 519-528. [CrossRef]

270. Chow, R.D.; Chen, S. Sno-derived RNAs are prevalent molecular markers of cancer immunity. Oncogene 2018, 37, 6442-6462. [CrossRef]

271. Stepanov, G.A.; Filippova, J.A.; Komissarov, A.B.; Kuligina, E.V.; Richter, V.A.; Semenov, D.V. Regulatory role of small nucleolar RNAs in human diseases. BioMed Res. Int. 2015, 2015, 206849. [CrossRef]

272. Su, Y.; Guarnera, M.A.; Fang, H.; Jiang, F. Small non-coding RNA biomarkers in sputum for lung cancer diagnosis. Mol. Cancer 2016, 15, 36. [CrossRef]

273. Schmitz, U.; Naderi-Meshkin, H.; Gupta, S.K.; Wolkenhauer, O.; Vera, J. The RNA world in the 21st century-a systems approach to finding non-coding keys to clinical questions. Brief. Bioinform. 2016, 17, 380-392. [CrossRef]

274. Han, D.; Wang, M.; Ma, N.; Xu, Y.; Jiang, Y.; Gao, X. Long noncoding RNAs: Novel players in colorectal cancer. Cancer Lett. 2015, 361, 13-21. [CrossRef]

275. Wang, M.; Zhou, L.; Yu, F.; Zhang, Y.; Li, P.; Wang, K. The functional roles of exosomal long non-coding RNAs in cancer. Cell. Mol. Life Sci. 2019, 76, 2059-2076. [CrossRef]

276. Lin, T.; Hou, P.F.; Meng, S.; Chen, F.; Jiang, T.; Li, M.L.; Shi, M.L.; Liu, J.J.; Zheng, J.N.; Bai, J. Emerging Roles of p53 Related lncRNAs in Cancer Progression: A Systematic Review. Int. J. Biol. Sci. 2019, 15, 1287-1298. [CrossRef]

277. Schmitt, A.M.; Chang, H.Y. Long Noncoding RNAs in Cancer Pathways. Cancer Cell 2016, 29, $452-463$. [CrossRef] 
278. Li, Q.; Shao, Y.; Zhang, X.; Zheng, T.; Miao, M.; Qin, L.; Wang, B.; Ye, G.; Xiao, B.; Guo, J. Plasma long noncoding RNA protected by exosomes as a potential stable biomarker for gastric cancer. Tumour Biol. J. Int. Soc. Oncodev. Biol. Med. 2015, 36, 2007-2012. [CrossRef]

279. Naderi-Meshkin, H.; Lai, X.; Amirkhah, R.; Vera, J.; Rasko, J.E.J.; Schmitz, U. Exosomal lncRNAs and cancer: Connecting the missing links. Bioinformatics 2019, 35, 352-360. [CrossRef]

280. Zhou, H.; Wang, F.; Chen, H.; Tan, Q.; Qiu, S.; Chen, S.; Jing, W.; Yu, M.; Liang, C.; Ye, S.; et al. Increased expression of long-noncoding RNA ZFAS1 is associated with epithelial-mesenchymal transition of gastric cancer. Aging (Albany N. Y.) 2016, 8, 2023-2038. [CrossRef]

281. Xie, H.; Ma, H.; Zhou, D. Plasma HULC as a promising novel biomarker for the detection of hepatocellular carcinoma. BioMed Res. Int. 2013, 2013, 136106. [CrossRef]

282. Tong, Y.S.; Wang, X.W.; Zhou, X.L.; Liu, Z.H.; Yang, T.X.; Shi, W.H.; Xie, H.W.; Lv, J.; Wu, Q.Q.; Cao, X.F. Identification of the long non-coding RNA POU3F3 in plasma as a novel biomarker for diagnosis of esophageal squamous cell carcinoma. Mol. Cancer 2015, 14, 3. [CrossRef]

283. Tang, Q.; Ni, Z.; Cheng, Z.; Xu, J.; Yu, H.; Yin, P. Three circulating long non-coding RNAs act as biomarkers for predicting NSCLC. Cell. Physiol. Biochem. Int. J. Exp. Cell. Physiol. Biochem. Pharmacol. 2015, 37, 1002-1009. [CrossRef]

284. Tang, J.; Jiang, R.; Deng, L.; Zhang, X.; Wang, K.; Sun, B. Circulation long non-coding RNAs act as biomarkers for predicting tumorigenesis and metastasis in hepatocellular carcinoma. Oncotarget 2015, 6, 4505-4515. [CrossRef]

285. Qu, L.; Ding, J.; Chen, C.; Wu, Z.J.; Liu, B.; Gao, Y.; Chen, W.; Liu, F.; Sun, W.; Li, X.F.; et al. Exosome-Transmitted lncARSR Promotes Sunitinib Resistance in Renal Cancer by Acting as a Competing Endogenous RNA. Cancer Cell 2016, 29, 653-668. [CrossRef]

286. Liu, X.F.; Thin, K.Z.; Ming, X.L.; Shuo, L.; Ping, L.; Man, Z.; Li, N.D.; Tu, J.C. Small Nucleolar RNA Host Gene 18 Acts as a Tumor Suppressor and a Diagnostic Indicator in Hepatocellular Carcinoma. Technol. Cancer Res. Treat. 2018, 17. [CrossRef]

287. Liu, M.; Xing, L.Q.; Liu, Y.J. A three-long noncoding RNA signature as a diagnostic biomarker for differentiating between triple-negative and non-triple-negative breast cancers. Medicine 2017, 96, e6222. [CrossRef]

288. Kamel, L.M.; Atef, D.M.; Mackawy, A.M.; Shalaby, S.M.; Abdelraheim, N. Circulating long non-coding RNA GAS5 and SOX2OT as potential biomarkers for diagnosis and prognosis of non-small cell lung cancer. Biotechnol. Appl. Biochem. 2019. [CrossRef]

289. Isin, M.; Ozgur, E.; Cetin, G.; Erten, N.; Aktan, M.; Gezer, U.; Dalay, N. Investigation of circulating lncRNAs in B-cell neoplasms. Clin. Chim. Acta Int. J. Clin. Chem. 2014, 431, 255-259. [CrossRef]

290. Gao, S.; Xu, X.; Wang, Y.; Zhang, W.; Wang, X. Diagnostic utility of plasma lncRNA small nucleolar RNA host gene 1 in patients with hepatocellular carcinoma. Mol. Med. Rep. 2018, 18, 3305-3313. [CrossRef]

291. Dong, L.; Qi, P.; Xu, M.D.; Ni, S.J.; Huang, D.; Xu, Q.H.; Weng, W.W.; Tan, C.; Sheng, W.Q.; Zhou, X.Y.; et al. Circulating CUDR, LSINCT-5 and PTENP1 long noncoding RNAs in sera distinguish patients with gastric cancer from healthy controls. Int. J. Cancer J. Int. Cancer 2015, 137, 1128-1135. [CrossRef]

292. Zhang, R.; Xia, Y.; Wang, Z.; Zheng, J.; Chen, Y.; Li, X.; Wang, Y.; Ming, H. Serum long non coding RNA MALAT-1 protected by exosomes is up-regulated and promotes cell proliferation and migration in non-small cell lung cancer. Biochem. Biophys. Res. Commun. 2017, 490, 406-414. [CrossRef]

293. Wang, L.; Duan, W.; Yan, S.; Xie, Y.; Wang, C. Circulating long non-coding RNA colon cancer-associated transcript 2 protected by exosome as a potential biomarker for colorectal cancer. Biomed. Pharmacother. 2019, 113, 108758. [CrossRef]

294. Liu, T.; Zhang, X.; Gao, S.; Jing, F.; Yang, Y.; Du, L.; Zheng, G.; Li, P.; Li, C.; Wang, C. Exosomal long noncoding RNA CRNDE-h as a novel serum-based biomarker for diagnosis and prognosis of colorectal cancer. Oncotarget 2016, 7, 85551-85563. [CrossRef]

295. Berrondo, C.; Flax, J.; Kucherov, V.; Siebert, A.; Osinski, T.; Rosenberg, A.; Fucile, C.; Richheimer, S.; Beckham, C.J. Expression of the Long Non-Coding RNA HOTAIR Correlates with Disease Progression in Bladder Cancer and Is Contained in Bladder Cancer Patient Urinary Exosomes. PLoS ONE 2016, 11, e0147236. [CrossRef] 
296. Nilsson, J.; Skog, J.; Nordstrand, A.; Baranov, V.; Mincheva-Nilsson, L.; Breakefield, X.O.; Widmark, A. Prostate cancer-derived urine exosomes: A novel approach to biomarkers for prostate cancer. Br. J. Cancer 2009, 100, 1603-1607. [CrossRef]

297. McKiernan, J.; Donovan, M.J.; O’Neill, V.; Bentink, S.; Noerholm, M.; Belzer, S.; Skog, J.; Kattan, M.W.; Partin, A.; Andriole, G.; et al. A Novel Urine Exosome Gene Expression Assay to Predict High-grade Prostate Cancer at Initial Biopsy. JAMA Oncol. 2016, 2, 882-889. [CrossRef]

298. Isin, M.; Uysaler, E.; Ozgur, E.; Koseoglu, H.; Sanli, O.; Yucel, O.B.; Gezer, U.; Dalay, N. Exosomal lncRNA-p21 levels may help to distinguish prostate cancer from benign disease. Front. Genet. 2015, 6, 168. [CrossRef]

299. Donovan, M.J.; Noerholm, M.; Bentink, S.; Belzer, S.; Skog, J.; O’Neill, V.; Cochran, J.S.; Brown, G.A. A molecular signature of PCA3 and ERG exosomal RNA from non-DRE urine is predictive of initial prostate biopsy result. Prostate Cancer Prostatic Dis. 2015, 18, 370-375. [CrossRef]

300. Tang, H.; Wu, Z.; Zhang, J.; Su, B. Salivary lncRNA as a potential marker for oral squamous cell carcinoma diagnosis. Mol. Med. Rep. 2013, 7, 761-766. [CrossRef]

301. Xie, Z.; Chen, X.; Li, J.; Guo, Y.; Li, H.; Pan, X.; Jiang, J.; Liu, H.; Wu, B. Salivary HOTAIR and PVT1 as novel biomarkers for early pancreatic cancer. Oncotarget 2016, 7, 25408-25419. [CrossRef]

302. Ge, X.; Wang, Y.; Nie, J.; Li, Q.; Tang, L.; Deng, X.; Wang, F.; Xu, B.; Wu, X.; Zhang, X.; et al. The diagnostic/prognostic potential and molecular functions of long non-coding RNAs in the exosomes derived from the bile of human cholangiocarcinoma. Oncotarget 2017, 8, 69995-70005. [CrossRef]

303. Shao, Y.; Ye, M.; Jiang, X.; Sun, W.; Ding, X.; Liu, Z.; Ye, G.; Zhang, X.; Xiao, B.; Guo, J. Gastric juice long noncoding RNA used as a tumor marker for screening gastric cancer. Cancer 2014, 120, 3320-3328. [CrossRef]

304. Shah, M.Y.; Ferracin, M.; Pileczki, V.; Chen, B.; Redis, R.; Fabris, L.; Zhang, X.; Ivan, C.; Shimizu, M.; Rodriguez-Aguayo, C.; et al. Cancer-associated rs6983267 SNP and its accompanying long noncoding RNA CCAT2 induce myeloid malignancies via unique SNP-specific RNA mutations. Genome Res. 2018, 28, $432-447$. [CrossRef]

305. Redis, R.S.; Vela, L.E.; Lu, W.; Ferreira de Oliveira, J.; Ivan, C.; Rodriguez-Aguayo, C.; Adamoski, D.; Pasculli, B.; Taguchi, A.; Chen, Y.; et al. Allele-Specific Reprogramming of Cancer Metabolism by the Long Non-coding RNA CCAT2. Mol. Cell 2016, 61, 520-534. [CrossRef]

306. Ghafouri-Fard, S.; Taheri, M. Colon Cancer-Associated Transcripts 1 and 2: Roles and functions in human cancers. J. Cell. Physiol. 2019. [CrossRef]

307. Shao, T.; Huang, J.; Zheng, Z.; Wu, Q.; Liu, T.; Lv, X. SCCA, TSGF, and the Long Non-Coding RNA AC007271.3 are Effective Biomarkers for Diagnosing Oral Squamous Cell Carcinoma. Cell. Physiol. Biochem. 2018, 47, 26-38. [CrossRef]

308. Zhao, S.Y.; Wang, J.; Ouyang, S.B.; Huang, Z.K.; Liao, L. Salivary Circular RNAs Hsa_Circ_0001874 and Hsa_Circ_0001971 as Novel Biomarkers for the Diagnosis of Oral Squamous Cell Carcinoma. Cell. Physiol. Biochem. 2018, 47, 2511-2521. [CrossRef]

309. Fan, C.M.; Wang, J.P.; Tang, Y.Y.; Zhao, J.; He, S.Y.; Xiong, F.; Guo, C.; Xiang, B.; Zhou, M.; Li, X.L.; et al. circMAN1A2 could serve as a novel serum biomarker for malignant tumors. Cancer Sci. 2019, 110, 2180-2188. [CrossRef]

310. He, B.; Zeng, J.; Chao, W.; Chen, X.; Huang, Y.; Deng, K.; Huang, Z.; Li, J.; Dai, M.; Chen, S.; et al. Serum long non-coding RNAs MALAT1, AFAP1-AS1 and AL359062 as diagnostic and prognostic biomarkers for nasopharyngeal carcinoma. Oncotarget 2017, 8, 41166-41177. [CrossRef]

311. Shuai, M.; Hong, J.; Huang, D.; Zhang, X.; Tian, Y. Upregulation of circRNA_0000285 serves as a prognostic biomarker for nasopharyngeal carcinoma and is involved in radiosensitivity. Oncol. Lett. 2018, 16, 6495-6501. [CrossRef]

312. Sun, K.; Zhao, X.; Wan, J.; Yang, L.; Chu, J.; Dong, S.; Yin, H.; Ming, L.; He, F. The diagnostic value of long non-coding RNA MIR31HG and its role in esophageal squamous cell carcinoma. Life Sci. 2018, 202, 124-130. [CrossRef]

313. Wang, W.; He, X.; Zheng, Z.; Ma, X.; Hu, X.; Wu, D.; Wang, M. Serum HOTAIR as a novel diagnostic biomarker for esophageal squamous cell carcinoma. Mol. Cancer 2017, 16, 75. [CrossRef]

314. Wang, Y.; Jing, W.; Ma, W.; Liang, C.; Chai, H.; Tu, J. Down-regulation of long non-coding RNA GAS5-AS1 and its prognostic and diagnostic significance in hepatocellular carcinoma. Cancer Biomark. 2018, 22, 227-236. [CrossRef] 
315. Luo, P.; Liang, C.; Zhang, X.; Liu, X.; Wang, Y.; Wu, M.; Feng, X.; Tu, J. Identification of long non-coding RNA ZFAS1 as a novel biomarker for diagnosis of HCC. Biosci. Rep. 2018, 38. [CrossRef]

316. Ma, X.; Wang, X.; Yang, C.; Wang, Z.; Han, B.; Wu, L.; Zhuang, L. DANCR Acts as a Diagnostic Biomarker and Promotes Tumor Growth and Metastasis in Hepatocellular Carcinoma. Anticancer Res. 2016, 36, 6389-6398. [CrossRef]

317. Li, J.; Wang, X.; Tang, J.; Jiang, R.; Zhang, W.; Ji, J.; Sun, B. HULC and Linc00152 Act as Novel Biomarkers in Predicting Diagnosis of Hepatocellular Carcinoma. Cell. Physiol. Biochem. 2015, 37, 687-696. [CrossRef]

318. Jing, W.; Gao, S.; Zhu, M.; Luo, P.; Jing, X.; Chai, H.; Tu, J. Potential diagnostic value of lncRNA SPRY4-IT1 in hepatocellular carcinoma. Oncol. Rep. 2016, 36, 1085-1092. [CrossRef]

319. Shaker, O.G.; Ayoub, S.E.; Abdelwahed, M.Y.; Ahmed, N.A.; Hassan, E.A.; Ahmed, T.I.; Abousarie, M.A. Evaluation of serum long noncoding RNA NEAT and MiR-129-5p in hepatocellular carcinoma. IUBMB Life 2019. [CrossRef]

320. Wang, Z.F.; Hu, R.; Pang, J.M.; Zhang, G.Z.; Yan, W.; Li, Z.N. Serum long noncoding RNA LRB1 as a potential biomarker for predicting the diagnosis and prognosis of human hepatocellular carcinoma. Oncol. Lett. 2018, 16, 1593-1601. [CrossRef]

321. Zheng, Z.K.; Pang, C.; Yang, Y.; Duan, Q.; Zhang, J.; Liu, W.C. Serum long noncoding RNA urothelial carcinoma-associated 1: A novel biomarker for diagnosis and prognosis of hepatocellular carcinoma. J. Int. Med. Res. 2018, 46, 348-356. [CrossRef]

322. Zeng, Z.; Dong, J.; Li, Y.; Dong, Z.; Liu, Z.; Huang, J.; Wang, Y.; Zhen, Y.; Lu, Y. The expression level and clinical significance of lncRNA X91348 in hepatocellular carcinoma. Artif. Cells Nanomed. Biotechnol. 2019, 47, 3067-3071. [CrossRef]

323. Yu, J.; Han, J.; Zhang, J.; Li, G.; Liu, H.; Cui, X.; Xu, Y.; Li, T.; Liu, J.; Wang, C. The long noncoding RNAs PVT1 and uc002mbe.2 in sera provide a new supplementary method for hepatocellular carcinoma diagnosis. Medicine (Baltim.) 2016, 95, e4436. [CrossRef]

324. Wang, K.; Guo, W.X.; Li, N.; Gao, C.F.; Shi, J.; Tang, Y.F.; Shen, F.; Wu, M.C.; Liu, S.R.; Cheng, S.Q. Serum LncRNAs Profiles Serve as Novel Potential Biomarkers for the Diagnosis of HBV-Positive Hepatocellular Carcinoma. PLoS ONE 2015, 10, e0144934. [CrossRef]

325. Kamel, M.M.; Matboli, M.; Sallam, M.; Montasser, I.F.; Saad, A.S.; El-Tawdi, A.H.F. Investigation of long noncoding RNAs expression profile as potential serum biomarkers in patients with hepatocellular carcinoma. Transl. Res. 2016, 168, 134-145. [CrossRef]

326. Sun, L.; Su, Y.; Liu, X.; Xu, M.; Chen, X.; Zhu, Y.; Guo, Z.; Bai, T.; Dong, L.; Wei, C.; et al. Serum and exosome long non coding RNAs as potential biomarkers for hepatocellular carcinoma. J. Cancer 2018, 9, 2631-2639. [CrossRef]

327. Xu, H.; Chen, Y.; Dong, X.; Wang, X. Serum Exosomal Long Noncoding RNAs ENSG00000258332.1 and LINC00635 for the Diagnosis and Prognosis of Hepatocellular Carcinoma. Cancer Epidemiol. Prev. Biomark. 2018, 27, 710-716. [CrossRef]

328. Zhang, X.; Zhou, H.; Jing, W.; Luo, P.; Qiu, S.; Liu, X.; Zhu, M.; Liang, C.; Yu, M.; Tu, J. The Circular RNA hsa_circ_0001445 Regulates the Proliferation and Migration of Hepatocellular Carcinoma and May Serve as a Diagnostic Biomarker. Dis. Markers 2018, 2018, 3073467. [CrossRef]

329. Li, Z.; Zhou, Y.; Yang, G.; He, S.; Qiu, X.; Zhang, L.; Deng, Q.; Zheng, F. Using circular RNA SMARCA5 as a potential novel biomarker for hepatocellular carcinoma. Clin. Chim. Acta 2019, 492, 37-44. [CrossRef]

330. Shi, J.; Li, X.; Zhang, F.; Kong, L.; Zhang, X.; Cheng, Y.; Guan, Q.; Cao, X.; Zhu, W.; Ou, K.; et al. The Plasma LncRNA Acting as Fingerprint in Hilar Cholangiocarcinoma. Cell. Physiol. Biochem. 2018, 49, 1694-1702. [CrossRef]

331. Liu, Y.; Feng, W.; Liu, W.; Kong, X.; Li, L.; He, J.; Wang, D.; Zhang, M.; Zhou, G.; Xu, W.; et al. Circulating lncRNA ABHD11-AS1 serves as a biomarker for early pancreatic cancer diagnosis. J. Cancer 2019, 10, 3746-3756. [CrossRef]

332. Wang, Y.; Li, Z.; Zheng, S.; Zhou, Y.; Zhao, L.; Ye, H.; Zhao, X.; Gao, W.; Fu, Z.; Zhou, Q.; et al. Expression profile of long non-coding RNAs in pancreatic cancer and their clinical significance as biomarkers. Oncotarget 2015, 6, 35684-35698. [CrossRef]

333. Yang, F.; Liu, D.Y.; Guo, J.T.; Ge, N.; Zhu, P.; Liu, X.; Wang, S.; Wang, G.X.; Sun, S.Y. Circular RNA circ-LDLRAD3 as a biomarker in diagnosis of pancreatic cancer. World J. Gastroenterol. 2017, 23, 8345-8354. [CrossRef] 
334. Yang, Z.; Sun, Y.; Liu, R.; Shi, Y.; Ding, S. Plasma long noncoding RNAs PANDAR, FOXD2-AS1, and SMARCC2 as potential novel diagnostic biomarkers for gastric cancer. Cancer Manag. Res. 2019, 11, 6175-6184. [CrossRef]

335. Zheng, R.; Liang, J.; Lu, J.; Li, S.; Zhang, G.; Wang, X.; Liu, M.; Wang, W.; Chu, H.; Tao, G.; et al. Genome-wide long non-coding RNAs identified a panel of novel plasma biomarkers for gastric cancer diagnosis. Gastric Cancer 2019, 22, 731-741. [CrossRef]

336. Ghaedi, H.; Mozaffari, M.A.N.; Salehi, Z.; Ghasemi, H.; Zadian, S.S.; Alipoor, S.; Hadianpour, S.; Alipoor, B. Co-expression profiling of plasma miRNAs and long noncoding RNAs in gastric cancer patients. Gene 2019, 687, 135-142. [CrossRef]

337. Tan, L.; Yang, Y.; Shao, Y.; Zhang, H.; Guo, J. Plasma lncRNA-GACAT2 is a valuable marker for the screening of gastric cancer. Oncol. Lett. 2016, 12, 4845-4849. [CrossRef]

338. Elsayed, E.T.; Salem, P.E.; Darwish, A.M.; Fayed, H.M. Plasma long non-coding RNA HOTAIR as a potential biomarker for gastric cancer. Int. J. Biol. Markers 2018, 33, 528-533. [CrossRef]

339. Liu, J.; Wang, J.; Song, Y.; Ma, B.; Luo, J.; Ni, Z.; Gao, P.; Sun, J.; Zhao, J.; Chen, X.; et al. A panel consisting of three novel circulating lncRNAs, is it a predictive tool for gastric cancer? J. Cell. Mol. Med. 2018, 22, 3605-3613. [CrossRef]

340. Gao, J.; Cao, R.; Mu, H. Long non-coding RNA UCA1 may be a novel diagnostic and predictive biomarker in plasma for early gastric cancer. Int. J. Clin. Exp. Pathol. 2015, 8, 12936-12942.

341. Zhang, K.; Shi, H.; Xi, H.; Wu, X.; Cui, J.; Gao, Y.; Liang, W.; Hu, C.; Liu, Y.; Li, J.; et al. Genome-Wide lncRNA Microarray Profiling Identifies Novel Circulating lncRNAs for Detection of Gastric Cancer. Theranostics 2017, 7, 213-227. [CrossRef]

342. Jin, C.; Shi, W.; Wang, F.; Shen, X.; Qi, J.; Cong, H.; Yuan, J.; Shi, L.; Zhu, B.; Luo, X.; et al. Long non-coding RNA HULC as a novel serum biomarker for diagnosis and prognosis prediction of gastric cancer. Oncotarget 2016, 7, 51763-51772. [CrossRef]

343. Liu, Y.; Zhang, Y.M.; Ma, F.B.; Pan, S.R.; Liu, B.Z. Long noncoding RNA HOXA11-AS promotes gastric cancer cell proliferation and invasion via SRSF1 and functions as a biomarker in gastric cancer. World J. Gastroenterol. 2019, 25, 2763-2775. [CrossRef]

344. Mohamed, W.A.; Schaalan, M.F.; Ramadan, B. The expression profiling of circulating miR-204, miR-182, and lncRNA H19 as novel potential biomarkers for the progression of peptic ulcer to gastric cancer. J. Cell. Biochem. 2019, 120, 13464-13477. [CrossRef]

345. Zhou, X.; Yin, C.; Dang, Y.; Ye, F.; Zhang, G. Identification of the long non-coding RNA H19 in plasma as a novel biomarker for diagnosis of gastric cancer. Sci. Rep. 2015, 5, 11516. [CrossRef]

346. Zong, W.; Feng, W.; Jiang, Y.; Ju, S.; Cui, M.; Jing, R. Evaluating the diagnostic and prognostic value of serum long non-coding RNA CTC-497E21.4 in gastric cancer. Clin. Chem. Lab. Med. 2019, 57, 1063-1072. [CrossRef]

347. Fu, M.; Huang, Z.; Zang, X.; Pan, L.; Liang, W.; Chen, J.; Qian, H.; Xu, W.; Jiang, P.; Zhang, X. Long noncoding RNA LINC00978 promotes cancer growth and acts as a diagnostic biomarker in gastric cancer. Cell Prolif. 2018, 51, e12425. [CrossRef]

348. Lu, Q.; Yu, T.; Ou, X.; Cao, D.; Xie, T.; Chen, X. Potential lncRNA diagnostic biomarkers for early gastric cancer. Mol. Med. Rep. 2017, 16, 9545-9552. [CrossRef]

349. Arita, T.; Ichikawa, D.; Konishi, H.; Komatsu, S.; Shiozaki, A.; Shoda, K.; Kawaguchi, T.; Hirajima, S.; Nagata, H.; Kubota, T.; et al. Circulating long non-coding RNAs in plasma of patients with gastric cancer. Anticancer Res. 2013, 33, 3185-3193.

350. Lin, L.Y.; Yang, L.; Zeng, Q.; Wang, L.; Chen, M.L.; Zhao, Z.H.; Ye, G.D.; Luo, Q.C.; Lv, P.Y.; Guo, Q.W.; et al. Tumor-originated exosomal lncUEGC1 as a circulating biomarker for early-stage gastric cancer. Mol. Cancer 2018, 17, 84. [CrossRef]

351. Virgilio, E.; Giarnieri, E.; Giovagnoli, M.R.; Montagnini, M.; Proietti, A.; D’Urso, R.; Mercantini, P.; Balducci, G.; Cavallini, M. Long non-coding RNAs in the gastric juice of gastric cancer patients. Pathol. Res. Pract. 2018, 214, 1239-1246. [CrossRef]

352. Li, W.H.; Song, Y.C.; Zhang, H.; Zhou, Z.J.; Xie, X.; Zeng, Q.N.; Guo, K.; Wang, T.; Xia, P.; Chang, D.M. Decreased Expression of Hsa_circ_00001649 in Gastric Cancer and Its Clinical Significance. Dis. Markers 2017, 2017, 4587698. [CrossRef]

353. Li, T.; Shao, Y.; Fu, L.; Xie, Y.; Zhu, L.; Sun, W.; Yu, R.; Xiao, B.; Guo, J. Plasma circular RNA profiling of patients with gastric cancer and their droplet digital RT-PCR detection. J. Mol. Med. (Berl.) 2018, 96, 85-96. [CrossRef] 
354. Huang, M.; He, Y.R.; Liang, L.C.; Huang, Q.; Zhu, Z.Q. Circular RNA hsa_circ_0000745 may serve as a diagnostic marker for gastric cancer. World J. Gastroenterol. 2017, 23, 6330-6338. [CrossRef]

355. Sun, H.; Tang, W.; Rong, D.; Jin, H.; Fu, K.; Zhang, W.; Liu, Z.; Cao, H.; Cao, X. Hsa_circ_0000520, a potential new circular RNA biomarker, is involved in gastric carcinoma. Cancer Biomark. 2018, 21, 299-306. [CrossRef]

356. Tang, W.; Fu, K.; Sun, H.; Rong, D.; Wang, H.; Cao, H. CircRNA microarray profiling identifies a novel circulating biomarker for detection of gastric cancer. Mol. Cancer 2018, 17, 137. [CrossRef]

357. Chen, S.; Li, T.; Zhao, Q.; Xiao, B.; Guo, J. Using circular RNA hsa_circ_0000190 as a new biomarker in the diagnosis of gastric cancer. Clin. Chim. Acta 2017, 466, 167-171. [CrossRef]

358. Lu, J.; Zhang, P.Y.; Xie, J.W.; Wang, J.B.; Lin, J.X.; Chen, Q.Y.; Cao, L.L.; Huang, C.M.; Li, P.; Zheng, C.H. Hsa_circ_0000467 promotes cancer progression and serves as a diagnostic and prognostic biomarker for gastric cancer. J. Clin. Lab. Anal. 2019, 33, e22726. [CrossRef]

359. Zhao, Q.; Chen, S.; Li, T.; Xiao, B.; Zhang, X. Clinical values of circular RNA 0000181 in the screening of gastric cancer. J. Clin. Lab. Anal. 2018, 32, e22333. [CrossRef]

360. Abedini, P.; Fattahi, A.; Agah, S.; Talebi, A.; Beygi, A.H.; Amini, S.M.; Mirzaei, A.; Akbari, A. Expression analysis of circulating plasma long noncoding RNAs in colorectal cancer: The relevance of lncRNAs ATB and CCAT1 as potential clinical hallmarks. J. Cell. Physiol. 2019. [CrossRef]

361. Liu, H.; Ye, D.; Chen, A.; Tan, D.; Zhang, W.; Jiang, W.; Wang, M.; Zhang, X. A pilot study of new promising non-coding RNA diagnostic biomarkers for early-stage colorectal cancers. Clin. Chem. Lab. Med. 2019, 57, 1073-1083. [CrossRef]

362. Shaker, O.G.; Senousy, M.A.; Elbaz, E.M. Association of rs6983267 at 8q24, HULC rs7763881 polymorphisms and serum lncRNAs CCAT2 and HULC with colorectal cancer in Egyptian patients. Sci. Rep. 2017, 7, 16246. [CrossRef]

363. Dai, M.; Chen, X.; Mo, S.; Li, J.; Huang, Z.; Huang, S.; Xu, J.; He, B.; Zou, Y.; Chen, J.; et al. Meta-signature LncRNAs serve as novel biomarkers for colorectal cancer: Integrated bioinformatics analysis, experimental validation and diagnostic evaluation. Sci. Rep. 2017, 7, 46572. [CrossRef]

364. Feng, W.; Zong, W.; Li, Y.; Shen, X.; Cui, X.; Ju, S. Abnormally expressed long noncoding RNA B3GALT5-AS1 may serve as a biomarker for the diagnostic and prognostic of gastric cancer. J. Cell. Biochem. 2019. [CrossRef]

365. Wang, C.; Yu, J.; Han, Y.; Li, L.; Li, J.; Li, T.; Qi, P. Long non-coding RNAs LOC285194, RP11-462C24.1 and Nbla12061 in serum provide a new approach for distinguishing patients with colorectal cancer from healthy controls. Oncotarget 2016, 7, 70769-70778. [CrossRef]

366. Wang, R.; Du, L.; Yang, X.; Jiang, X.; Duan, W.; Yan, S.; Xie, Y.; Zhu, Y.; Wang, Q.; Wang, L.; et al. Identification of long noncoding RNAs as potential novel diagnosis and prognosis biomarkers in colorectal cancer. J. Cancer Res. Clin. Oncol. 2016, 142, 2291-2301. [CrossRef]

367. Zhao, W.; Song, M.; Zhang, J.; Kuerban, M.; Wang, H. Combined identification of long non-coding RNA CCAT1 and HOTAIR in serum as an effective screening for colorectal carcinoma. Int. J. Clin. Exp. Pathol. 2015, 8, 14131-14140.

368. Hu, D.; Zhan, Y.; Zhu, K.; Bai, M.; Han, J.; Si, Y.; Zhang, H.; Kong, D. Plasma Exosomal Long Non-Coding RNAs Serve as Biomarkers for Early Detection of Colorectal Cancer. Cell. Physiol. Biochem. 2018, 51, 2704-2715. [CrossRef]

369. Dong, L.; Lin, W.; Qi, P.; Xu, M.D.; Wu, X.; Ni, S.; Huang, D.; Weng, W.W.; Tan, C.; Sheng, W.; et al. Circulating Long RNAs in Serum Extracellular Vesicles: Their Characterization and Potential Application as Biomarkers for Diagnosis of Colorectal Cancer. Cancer Epidemiol. Biomark. Prev. 2016, 25, 1158-1166. [CrossRef]

370. Ji, W.; Qiu, C.; Wang, M.; Mao, N.; Wu, S.; Dai, Y. Hsa_circ_0001649: A circular RNA and potential novel biomarker for colorectal cancer. Biochem. Biophy. Res. Commun. 2018, 497, 122-126. [CrossRef]

371. Li, X.N.; Wang, Z.J.; Ye, C.X.; Zhao, B.C.; Huang, X.X.; Yang, L. Circular RNA circVAPA is up-regulated and exerts oncogenic properties by sponging miR-101 in colorectal cancer. Biomed. Pharmacother. 2019, 112, 108611. [CrossRef]

372. Luo, J.; Li, Q.; Pan, J.; Li, L.; Fang, L.; Zhang, Y. Expression level of long noncoding RNA H19 in plasma of patients with nonsmall cell lung cancer and its clinical significance. J. Cancer Res. Ther. 2018, 14, 860-863. [CrossRef]

373. Li, N.; Wang, Y.; Liu, X.; Luo, P.; Jing, W.; Zhu, M.; Tu, J. Identification of Circulating Long Noncoding RNA HOTAIR as a Novel Biomarker for Diagnosis and Monitoring of Non-Small Cell Lung Cancer. Technol. Cancer Res. Treat. 2017, 16, 1060-1066. [CrossRef] 
374. Li, N.; Feng, X.B.; Tan, Q.; Luo, P.; Jing, W.; Zhu, M.; Liang, C.; Tu, J.; Ning, Y. Identification of Circulating Long Noncoding RNA Linc00152 as a Novel Biomarker for Diagnosis and Monitoring of Non-Small-Cell Lung Cancer. Dis. Markers 2017, 2017, 7439698. [CrossRef]

375. Lin, Y.; Leng, Q.; Zhan, M.; Jiang, F. A Plasma Long Noncoding RNA Signature for Early Detection of Lung Cancer. Transl. Oncol. 2018, 11, 1225-1231. [CrossRef]

376. Tan, Q.; Zuo, J.; Qiu, S.; Yu, Y.; Zhou, H.; Li, N.; Wang, H.; Liang, C.; Yu, M.; Tu, J. Identification of circulating long non-coding RNA GAS5 as a potential biomarker for non-small cell lung cancer diagnosisnon-small cell lung cancer, long non-coding RNA, plasma, GAS5, biomarker. Int. J. Oncol. 2017, 50, 1729-1738. [CrossRef]

377. Hu, X.; Bao, J.; Wang, Z.; Zhang, Z.; Gu, P.; Tao, F.; Cui, D.; Jiang, W. The plasma lncRNA acting as fingerprint in non-small-cell lung cancer. Tumour Biol. 2016, 37, 3497-3504. [CrossRef]

378. Wang, H.M.; Lu, J.H.; Chen, W.Y.; Gu, A.Q. Upregulated lncRNA-UCA1 contributes to progression of lung cancer and is closely related to clinical diagnosis as a predictive biomarker in plasma. Int. J. Clin. Exp. Med. 2015, 8, 11824-11830.

379. Liu, H.; Zhou, G.; Fu, X.; Cui, H.; Pu, G.; Xiao, Y.; Sun, W.; Dong, X.; Zhang, L.; Cao, S.; et al. Long noncoding RNA TUG1 is a diagnostic factor in lung adenocarcinoma and suppresses apoptosis via epigenetic silencing of BAX. Oncotarget 2017, 8, 101899-101910. [CrossRef]

380. Wan, L.; Zhang, L.; Fan, K.; Wang, J.J. Diagnostic significance of circulating long noncoding RNA PCAT6 in patients with non-small cell lung cancer. Onco Targets Ther. 2017, 10, 5695-5702. [CrossRef]

381. Tantai, J.; Hu, D.; Yang, Y.; Geng, J. Combined identification of long non-coding RNA XIST and HIF1A-AS1 in serum as an effective screening for non-small cell lung cancer. Int. J. Clin. Exp. Pathol. 2015, 8, 7887-7895.

382. Li, W.; Li, N.; Kang, X.; Shi, K. Circulating long non-coding RNA AFAP1-AS1 is a potential diagnostic biomarker for non-small cell lung cancer. Clin. Chim. Acta 2017, 475, 152-156. [CrossRef]

383. Xie, Y.; Zhang, Y.; Du, L.; Jiang, X.; Yan, S.; Duan, W.; Li, J.; Zhan, Y.; Wang, L.; Zhang, S.; et al. Circulating long noncoding RNA act as potential novel biomarkers for diagnosis and prognosis of non-small cell lung cancer. Mol. Oncol. 2018, 12, 648-658. [CrossRef]

384. Jiang, N.; Meng, X.; Mi, H.; Chi, Y.; Li, S.; Jin, Z.; Tian, H.; He, J.; Shen, W.; Tian, H.; et al. Circulating lncRNA XLOC_009167 serves as a diagnostic biomarker to predict lung cancer. Clin. Chim. Acta 2018, 486, 26-33. [CrossRef]

385. Li, C.; Lv, Y.; Shao, C.; Chen, C.; Zhang, T.; Wei, Y.; Fan, H.; Lv, T.; Liu, H.; Song, Y. Tumor-derived exosomal lncRNA GAS5 as a biomarker for early-stage non-small-cell lung cancer diagnosis. J. Cell. Physiol. 2019, 234, 20721-20727. [CrossRef]

386. Teng, Y.; Kang, H.; Chu, Y. Identification of an Exosomal Long Noncoding RNA SOX2-OT in Plasma as a Promising Biomarker for Lung Squamous Cell Carcinoma. Genet. Test. Mol. Biomark. 2019, 23, 235-240. [CrossRef]

387. Bai, Y.; Qu, Y.; Wu, Z.; Ren, Y.; Cheng, Z.; Lu, Y.; Hu, J.; Lou, J.; Zhao, J.; Chen, C.; et al. Absolute quantification and analysis of extracellular vesicle lncRNAs from the peripheral blood of patients with lung cancer based on multi-colour fluorescence chip-based digital PCR. Biosens. Bioelectron. 2019, 142, 111523. [CrossRef]

388. Wang, J.; Zhou, Y.; Lu, J.; Sun, Y.; Xiao, H.; Liu, M.; Tian, L. Combined detection of serum exosomal miR-21 and HOTAIR as diagnostic and prognostic biomarkers for laryngeal squamous cell carcinoma. Med. Oncol. 2014, 31, 148. [CrossRef]

389. Wu, Y.; Wang, Y.Q.; Weng, W.W.; Zhang, Q.Y.; Yang, X.Q.; Gan, H.L.; Yang, Y.S.; Zhang, P.P.; Sun, M.H.; $\mathrm{Xu}, \mathrm{M} . \mathrm{D}$; ; et al. A serum-circulating long noncoding RNA signature can discriminate between patients with clear cell renal cell carcinoma and healthy controls. Oncogenesis 2016, 5, e192. [CrossRef]

390. Li, G.; Zhang, Y.; Mao, J.; Hu, P.; Chen, Q.; Ding, W.; Pu, R. lncRNA TUC338 is a potential diagnostic biomarker for bladder cancer. J. Cell. Biochem. 2019. [CrossRef]

391. Wang, J.; Yang, K.; Yuan, W.; Gao, Z. Determination of Serum Exosomal H19 as a Noninvasive Biomarker for Bladder Cancer Diagnosis and Prognosis. Med. Sci. Monit. 2018, 24, 9307-9316. [CrossRef]

392. Zhang, S.; Du, L.; Wang, L.; Jiang, X.; Zhan, Y.; Li, J.; Yan, K.; Duan, W.; Zhao, Y.; Wang, L.; et al. Evaluation of serum exosomal LncRNA-based biomarker panel for diagnosis and recurrence prediction of bladder cancer. J. Cell. Mol. Med. 2019, 23, 1396-1405. [CrossRef]

393. Wen, J.J.; Ma, Y.D.; Yang, G.S.; Wang, G.M. Analysis of circulating long non-coding RNA UCA1 as potential biomarkers for diagnosis and prognosis of osteosarcoma. Eur. Rev. Med. Pharmacol. Sci. 2017, 21, 498-503. 
394. Du, L.; Duan, W.; Jiang, X.; Zhao, L.; Li, J.; Wang, R.; Yan, S.; Xie, Y.; Yan, K.; Wang, Q.; et al. Cell-free lncRNA expression signatures in urine serve as novel non-invasive biomarkers for diagnosis and recurrence prediction of bladder cancer. J. Cell. Mol. Med. 2018, 22, 2838-2845. [CrossRef]

395. Yazarlou, F.; Modarressi, M.H.; Mowla, S.J.; Oskooei, V.K.; Motevaseli, E.; Tooli, L.F.; Nekoohesh, L.; Eghbali, M.; Ghafouri-Fard, S.; Afsharpad, M. Urinary exosomal expression of long non-coding RNAs as diagnostic marker in bladder cancer. Cancer Manag. Res. 2018, 10, 6357-6365. [CrossRef]

396. Zhan, Y.; Du, L.; Wang, L.; Jiang, X.; Zhang, S.; Li, J.; Yan, K.; Duan, W.; Zhao, Y.; Wang, L.; et al. Expression signatures of exosomal long non-coding RNAs in urine serve as novel non-invasive biomarkers for diagnosis and recurrence prediction of bladder cancer. Mol. Cancer 2018, 17, 142. [CrossRef]

397. Duan, W.; Du, L.; Jiang, X.; Wang, R.; Yan, S.; Xie, Y.; Yan, K.; Wang, Q.; Wang, L.; Zhang, X.; et al. Identification of a serum circulating $\ln \mathrm{RNA}$ panel for the diagnosis and recurrence prediction of bladder cancer. Oncotarget 2016, 7, 78850-78858. [CrossRef]

398. Chen, X.; Chen, R.X.; Wei, W.S.; Li, Y.H.; Feng, Z.H.; Tan, L.; Chen, J.W.; Yuan, G.J.; Chen, S.L.; Guo, S.J.; et al. PRMT5 Circular RNA Promotes Metastasis of Urothelial Carcinoma of the Bladder through Sponging miR-30c to Induce Epithelial-Mesenchymal Transition. Clin. Cancer Res. 2018, 24, 6319-6330. [CrossRef]

399. Li, G.; Zhang, Y.; Mao, J.; Hu, P.; Chen, Q.; Ding, W.; Pu, R. LncRNA TUC338 is overexpressed in prostate carcinoma and downregulates miR-466. Gene 2019, 707, 224-230. [CrossRef]

400. Chen, Z.; Zhen, M.; Zhou, J. LncRNA BRE-AS1 interacts with miR-145-5p to regulate cancer cell proliferation and apoptosis in prostate carcinoma and has early diagnostic values. Biosci. Rep. 2019, 39. [CrossRef]

401. Ren, S.; Wang, F.; Shen, J.; Sun, Y.; Xu, W.; Lu, J.; Wei, M.; Xu, C.; Wu, C.; Zhang, Z.; et al. Long non-coding RNA metastasis associated in lung adenocarcinoma transcript 1 derived miniRNA as a novel plasma-based biomarker for diagnosing prostate cancer. Eur. J. Cancer 2013, 49, 2949-2959. [CrossRef]

402. Wang, T.; Qu, X.; Jiang, J.; Gao, P.; Zhao, D.; Lian, X.; Li, X. Diagnostic significance of urinary long non-coding PCA3 RNA in prostate cancer. Oncotarget 2017, 8, 58577-58586. [CrossRef]

403. Bayat, H.; Narouie, B.; Ziaee, S.M.; Mowla, S.J. Two long non-coding RNAs, Prcat17.3 and Prcat38, could efficiently discriminate benign prostate hyperplasia from prostate cancer. Prostate 2018, 78, 812-818. [CrossRef]

404. Zhang, W.; Ren, S.C.; Shi, X.L.; Liu, Y.W.; Zhu, Y.S.; Jing, T.L.; Wang, F.B.; Chen, R.; Xu, C.L.; Wang, H.Q.; et al. A novel urinary long non-coding RNA transcript improves diagnostic accuracy in patients undergoing prostate biopsy. Prostate 2015, 75, 653-661. [CrossRef]

405. Zhang, K.; Luo, Z.; Zhang, Y.; Zhang, L.; Wu, L.; Liu, L.; Yang, J.; Song, X.; Liu, J. Circulating lncRNA H19 in plasma as a novel biomarker for breast cancer. Cancer Biomark. 2016, 17, 187-194. [CrossRef]

406. Miao, Y.; Fan, R.; Chen, L.; Qian, H. Clinical Significance of Long Non-coding RNA MALAT1 Expression in Tissue and Serum of Breast Cancer. Ann. Clin. Lab. Sci. 2016, 46, 418-424.

407. Xu, N.; Chen, F.; Wang, F.; Lu, X.; Wang, X.; Lv, M.; Lu, C. Clinical significance of high expression of circulating serum lncRNA RP11-445H22.4 in breast cancer patients: A Chinese population-based study. Tumour Biol. 2015, 36, 7659-7665. [CrossRef]

408. Yin, W.B.; Yan, M.G.; Fang, X.; Guo, J.J.; Xiong, W.; Zhang, R.P. Circulating circular RNA hsa_circ_0001785 acts as a diagnostic biomarker for breast cancer detection. Clin. Chim. Acta 2018, 487, 363-368. [CrossRef]

409. Xu, H.; Gong, Z.; Shen, Y.; Fang, Y.; Zhong, S. Circular RNA expression in extracellular vesicles isolated from serum of patients with endometrial cancer. Epigenomics 2018, 10, 187-197. [CrossRef]

410. Naizhaer, G.; Kuerban, A.; Kuerban, R.; Zhou, P. Up-regulation of lncRNA FALEC indicates prognosis and diagnosis values in cervical cancer. Pathol. Res. Pract. 2019, 215, 152495. [CrossRef]

411. Sun, W.; Wang, L.; Zhao, D.; Wang, P.; Li, Y.; Wang, S. Four Circulating Long Non-Coding RNAs Act as Biomarkers for Predicting Cervical Cancer. Gynecol. Obstet. Investig. 2018, 83, 533-539. [CrossRef]

412. Zhang, X.; Mao, L.; Li, L.; He, Z.; Wang, N.; Song, Y. Long noncoding RNA GIHCG functions as an oncogene and serves as a serum diagnostic biomarker for cervical cancer. J. Cancer 2019, 10, 672-681. [CrossRef]

413. Yang, J.P.; Yang, X.J.; Xiao, L.; Wang, Y. Long noncoding RNA PVT1 as a novel serum biomarker for detection of cervical cancer. Eur. Rev. Med. Pharmacol. Sci. 2016, 20, 3980-3986.

414. Shen, X.; Zhang, Y.; Wu, X.; Guo, Y.; Shi, W.; Qi, J.; Cong, H.; Wang, X.; Wu, X.; Ju, S. Upregulated lncRNA-PCAT1 is closely related to clinical diagnosis of multiple myeloma as a predictive biomarker in serum. Cancer Biomark. 2017, 18, 257-263. [CrossRef] 
415. Pan, Y.; Chen, H.; Shen, X.; Wang, X.; Ju, S.; Lu, M.; Cong, H. Serum level of long noncoding RNA H19 as a diagnostic biomarker of multiple myeloma. Clin. Chim. Acta 2018, 480, 199-205. [CrossRef]

416. Min, W.; Dai, D.; Wang, J.; Zhang, D.; Zhang, Y.; Han, G.; Zhang, L.; Chen, C.; Li, X.; Li, Y.; et al. Long Noncoding RNA miR210HG as a Potential Biomarker for the Diagnosis of Glioma. PLoS ONE 2016, 11, e0160451. [CrossRef]

417. Zhang, D.; Liu, X.; Wei, B.; Qiao, G.; Jiang, T.; Chen, Z. Plasma lncRNA GAS8-AS1 as a Potential Biomarker of Papillary Thyroid Carcinoma in Chinese Patients. Int. J. Endocrinol. 2017, 2017, 2645904. [CrossRef]

418. Yang, C.; Wei, Y.; Yu, L.; Xiao, Y. Identification of Altered Circular RNA Expression in Serum Exosomes from Patients with Papillary Thyroid Carcinoma by High-Throughput Sequencing. Med. Sci. Monit. 2019, 25, 2785-2791. [CrossRef]

419. Zhu, K.; Niu, L.; Wang, J.; Wang, Y.; Zhou, J.; Wang, F.; Cheng, Y.; Zhang, Q.; Li, H. Circular RNA hsa_circ_0000885 Levels are Increased in Tissue and Serum Samples from Patients with Osteosarcoma. Med. Sci. Monit. 2019, 25, 1499-1505. [CrossRef]

420. Chen, X.; Gao, G.; Liu, S.; Yu, L.; Yan, D.; Yao, X.; Sun, W.; Han, D.; Dong, H. Long Noncoding RNA PVT1 as a Novel Diagnostic Biomarker and Therapeutic Target for Melanoma. BioMed Res. Int. 2017, 2017, 7038579. [CrossRef]

421. Zhao, W.; Liu, Y.; Zhang, C.; Duan, C. Multiple Roles of Exosomal Long Noncoding RNAs in Cancers. BioMed Res. Int. 2019, 2019, 1460572. [CrossRef]

422. Jiang, N.; Pan, J.; Fang, S.; Zhou, C.; Han, Y.; Chen, J.; Meng, X.; Jin, X.; Gong, Z. Liquid biopsy: Circulating exosomal long noncoding RNAs in cancer. Clin. Chim. Acta 2019, 495, 331-337. [CrossRef]

423. Sarfi, M.; Abbastabar, M.; Khalili, E. Long noncoding RNAs biomarker-based cancer assessment. J. Cell. Physiol. 2019, 234, 16971-16986. [CrossRef]

424. Zhou, Y.; Xia, L.; Lin, J.; Wang, H.; Oyang, L.; Tan, S.; Tian, Y.; Su, M.; Wang, H.; Cao, D.; et al. Exosomes in Nasopharyngeal Carcinoma. J. Cancer 2018, 9, 767-777. [CrossRef]

425. Peng, W.; Wang, J.; Shan, B.; Peng, Z.; Dong, Y.; Shi, W.; He, D.; Cheng, Y.; Zhao, W.; Zhang, C.; et al. Diagnostic and Prognostic Potential of Circulating Long Non-Coding RNAs in Non Small Cell Lung Cancer. Cell. Physiol. Biochem. 2018, 49, 816-827. [CrossRef]

426. Martignano, F.; Rossi, L.; Maugeri, A.; Galla, V.; Conteduca, V.; De Giorgi, U.; Casadio, V.; Schepisi, G. Urinary RNA-based biomarkers for prostate cancer detection. Clin. Chim. Acta 2017, 473, 96-105. [CrossRef]

427. Wu, P.G.; Zhang, Y.X. Long non-coding RNAs in prostate cancer: An update. Zhonghua Nan Ke Xue 2018, 24, 735-739.

428. Vlaeminck-Guillem, V. Extracellular Vesicles in Prostate Cancer Carcinogenesis, Diagnosis, and Management. Front. Oncol. 2018, 8, 222. [CrossRef]

429. Kahroba, H.; Hejazi, M.S.; Samadi, N. Exosomes: From carcinogenesis and metastasis to diagnosis and treatment of gastric cancer. Cell. Mol. Life Sci. 2019, 76, 1747-1758. [CrossRef]

430. Yang, C.; Kim, H.S.; Song, G.; Lim, W. The potential role of exosomes derived from ovarian cancer cells for diagnostic and therapeutic approaches. J. Cell. Physiol. 2019. [CrossRef]

431. Wieczorek, E.; Reszka, E. mRNA, microRNA and lncRNA as novel bladder tumor markers. Clin. Chim. Acta 2018, 477, 141-153. [CrossRef]

432. Nobili, L.; Ronchetti, D.; Agnelli, L.; Taiana, E.; Vinci, C.; Neri, A. Long Non-Coding RNAs in Multiple Myeloma. Genes (Basel) 2018, 9, 69. [CrossRef]

433. Dai, S.P.; Jin, J.; Li, W.M. Diagnostic efficacy of long non-coding RNA in lung cancer: A systematic review and meta-analysis. Postgrad. Med. J. 2018, 94, 578-587. [CrossRef]

434. Chen, S.; Zhang, Y.; Wu, X.; Zhang, C.; Li, G. Diagnostic Value of lncRNAs as Biomarker in Hepatocellular Carcinoma: An Updated Meta-Analysis. Can. J. Gastroenterol. Hepatol. 2018, 2018, 8410195. [CrossRef]

435. Ning, L.; Hu, Y.C.; Wang, S.; Lang, J.H. Altered long noncoding RNAs and survival outcomes in ovarian cancer: A systematic review and meta-analysis (PRISMA Compliant). Medicine (Baltim.) 2018, 97, e11481. [CrossRef]

436. Gong, Y.B.; Zou, Y.F. Clinical significance of lncRNA FAM83H-AS1 in ovarian cancer. Eur. Rev. Med. Pharmacol. Sci. 2019, 23, 4656-4662. [CrossRef]

437. Marks, L.S.; Fradet, Y.; Lim Deras, I.; Blase, A.; Mathis, J.; Aubin, S.M.J.; Cancio, A.T.; Desaulniers, M.; Ellis, W.J.; Rittenhouse, H.; et al. PCA3 Molecular Urine Assay for Prostate Cancer in Men Undergoing Repeat Biopsy. Urology 2007, 69, 532-535. [CrossRef] 
438. Newcomb, L.F.; Zheng, Y.; Faino, A.V.; Bianchi-Frias, D.; Cooperberg, M.R.; Brown, M.D.; Brooks, J.D.; Dash, A.; Fabrizio, M.D.; Gleave, M.E.; et al. Performance of PCA3 and TMPRSS2:ERG urinary biomarkers in prediction of biopsy outcome in the Canary Prostate Active Surveillance Study (PASS). Prostate Cancer Prostatic Dis. 2019. [CrossRef]

439. Rittenhouse, H.; Blase, A.; Shamel, B.; Schalken, J.; Groskopf, J. The Long and Winding Road to FDA Approval of a Novel Prostate Cancer Test: Our Story. Clin. Chem. 2013, 59, 32-34. [CrossRef]

440. Eger, N.; Schoppe, L.; Schuster, S.; Laufs, U.; Boeckel, J.N. Circular RNA Splicing. Adv. Exp. Med. Biol. 2018, 1087, 41-52. [CrossRef]

441. Jeck, W.R.; Sorrentino, J.A.; Wang, K.; Slevin, M.K.; Burd, C.E.; Liu, J.; Marzluff, W.F.; Sharpless, N.E. Circular RNAs are abundant, conserved, and associated with ALU repeats. RNA 2013, 19, 141-157. [CrossRef]

442. Arnaiz, E.; Sole, C.; Manterola, L.; Iparraguirre, L.; Otaegui, D.; Lawrie, C.H. CircRNAs and cancer: Biomarkers and master regulators. Semin. Cancer Biol. 2018. [CrossRef]

443. Dragomir, M.; Calin, G.A. Circular RNAs in Cancer-Lessons Learned From microRNAs. Front. Oncol. 2018, 8. [CrossRef]

444. Hsu, M.-T.; Coca-Prados, M. Electron microscopic evidence for the circular form of RNA in the cytoplasm of eukaryotic cells. Nature 1979, 280, 339-340. [CrossRef]

445. Ragan, C.; Goodall, G.J.; Shirokikh, N.E.; Preiss, T. Insights into the biogenesis and potential functions of exonic circular RNA. Sci. Rep. 2019, 9, 2048. [CrossRef]

446. Schneider, T.; Hung, L.H.; Schreiner, S.; Starke, S.; Eckhof, H.; Rossbach, O.; Reich, S.; Medenbach, J.; Bindereif, A. CircRNA-protein complexes: IMP3 protein component defines subfamily of circRNPs. Sci. Rep. 2016, 6, 31313. [CrossRef]

447. Wang, Y.; Liu, J.; Ma, J.; Sun, T.; Zhou, Q.; Wang, W.; Wang, G.; Wu, P.; Wang, H.; Jiang, L.; et al. Exosomal circRNAs: Biogenesis, effect and application in human diseases. Mol. Cancer 2019, 18, 116. [CrossRef]

448. Bolha, L.; Ravnik-Glavač, M.; Glavač, D. Circular RNAs: Biogenesis, Function, and a Role as Possible Cancer Biomarkers. Int. J. Genom. 2017, 2017, 6218353. [CrossRef]

449. Zhu, X.; Wang, X.; Wei, S.; Chen, Y.; Chen, Y.; Fan, X.; Han, S.; Wu, G. hsa_circ_0013958: A circular RNA and potential novel biomarker for lung adenocarcinoma. FEBS J. 2017, 284, 2170-2182. [CrossRef]

450. Hang, D.; Zhou, J.; Qin, N.; Zhou, W.; Ma, H.; Jin, G.; Hu, Z.; Dai, J.; Shen, H. A novel plasma circular RNA circFARSA is a potential biomarker for non-small cell lung cancer. Cancer Med. 2018, 7, 2783-2791. [CrossRef]

451. Liu, X.X.; Yang, Y.E.; Liu, X.; Zhang, M.Y.; Li, R.; Yin, Y.H.; Qu, Y.Q. A two-circular RNA signature as a noninvasive diagnostic biomarker for lung adenocarcinoma. J. Transl. Med. 2019, 17, 50. [CrossRef]

452. Li, J.; Li, H.; Lv, X.; Yang, Z.; Gao, M.; Bi, Y.; Zhang, Z.; Wang, S.; Cui, Z.; Zhou, B.; et al. Diagnostic performance of circular RNAs in human cancers: A systematic review and meta-analysis. Mol. Genet. Genom. Med. 2019, 7, e00749. [CrossRef]

453. Jiang, F.; Hong, F.; Shah, M.W.; Shen, X. Circular RNAs as diagnostic biomarkers in gastric cancer: A meta-analysis review. Pathol. Res. Pract. 2019, 215, 152419. [CrossRef]

454. Song, F.; Luo, H.; Xie, M.; Zhu, H.; Hou, Y. Microarray expression profile of circular RNAs in human body fluids. Forensic Sci. Int. Genet. Suppl. Ser. 2017, 6, e55-e56. [CrossRef]

455. Jafari Ghods, F. Circular RNA in Saliva. Adv. Exp. Med. Biol. 2018, 1087, 131-139. [CrossRef]

456. Shao, Y.; Li, J.; Lu, R.; Li, T.; Yang, Y.; Xiao, B.; Guo, J. Global circular RNA expression profile of human gastric cancer and its clinical significance. Cancer Med. 2017, 6, 1173-1180. [CrossRef]

457. Krishnan, P.; Damaraju, S. The Challenges and Opportunities in the Clinical Application of Noncoding RNAs: The Road Map for miRNAs and piRNAs in Cancer Diagnostics and Prognostics. Int. J. Genom. 2018, 2018, 5848046. [CrossRef]

458. Palazzo, A.F.; Lee, E.S. Non-coding RNA: What is functional and what is junk? Front. Genet. $2015,6,2$. [CrossRef]

459. Boland, C.R. Erratum to: Non-coding RNA: It's Not Junk. Dig. Dis. Sci. 2017, 62, 3260. [CrossRef]

460. Beyret, E.; Lin, H. Pinpointing the expression of piRNAs and function of the PIWI protein subfamily during spermatogenesis in the mouse. Dev. Biol. 2011, 355, 215-226. [CrossRef]

461. Liu, S.-L.; Sun, P.; Li, Y.; Liu, S.-S.; Lu, Y. Exosomes as critical mediators of cell-to-cell communication in cancer pathogenesis and their potential clinical application. Transl. Cancer Res. 2019, 8, 298-311. [CrossRef]

462. Wu, J.; Li, H.; Xie, H.; Wu, X.; Lan, P. The malignant role of exosomes in the communication among colorectal cancer cell, macrophage and microbiome. Carcinogenesis 2019, 40, 601-610. [CrossRef] 
463. Pichler, M.; Calin, G.A. MicroRNAs in cancer: From developmental genes in worms to their clinical application in patients. Br. J. Cancer 2015, 113, 569-573. [CrossRef]

464. Shah, M.Y.; Ferrajoli, A.; Sood, A.K.; Lopez-Berestein, G.; Calin, G.A. microRNA Therapeutics in Cancer-An Emerging Concept. EBioMedicine 2016, 12, 34-42. [CrossRef]

465. Wang, W.T.; Han, C.; Sun, Y.M.; Chen, T.Q.; Chen, Y.Q. Noncoding RNAs in cancer therapy resistance and targeted drug development. J. Hematol. Oncol. 2019, 12, 55. [CrossRef]

466. Van Roosbroeck, K.; Fanini, F.; Setoyama, T.; Ivan, C.; Rodriguez-Aguayo, C.; Fuentes-Mattei, E.; Xiao, L.; Vannini, I.; Redis, R.S.; D'Abundo, L.; et al. Combining Anti-Mir-155 with Chemotherapy for the Treatment of Lung Cancers. Clin. Cancer Res. 2017, 23, 2891-2904. [CrossRef]

467. Nishimura, M.; Jung, E.J.; Shah, M.Y.; Lu, C.; Spizzo, R.; Shimizu, M.; Han, H.D.; Ivan, C.; Rossi, S.; Zhang, X.; et al. Therapeutic synergy between microRNA and siRNA in ovarian cancer treatment. Cancer Discov. 2013, 3, 1302-1315. [CrossRef]

468. Cortez, M.A.; Nicoloso, M.S.; Shimizu, M.; Rossi, S.; Gopisetty, G.; Molina, J.R.; Carlotti, C., Jr.; Tirapelli, D.; Neder, L.; Brassesco, M.S.; et al. miR-29b and miR-125a regulate podoplanin and suppress invasion in glioblastoma. Genes Chromosomes Cancer 2010, 49, 981-990. [CrossRef]

469. Bayraktar, R.; Bertilaccio, M.T.S.; Calin, G.A. The Interaction Between Two Worlds: MicroRNAs and Toll-Like Receptors. Front. Immunol. 2019, 10, 1053. [CrossRef]

470. Cortez, M.A.; Anfossi, S.; Ramapriyan, R.; Menon, H.; Atalar, S.C.; Aliru, M.; Welsh, J.; Calin, G.A. Role of miRNAs in immune responses and immunotherapy in cancer. Genes Chromosomes Cancer 2019, 58, $244-253$. [CrossRef]

471. Smolle, M.A.; Calin, H.N.; Pichler, M.; Calin, G.A. Noncoding RNAs and immune checkpoints-clinical implications as cancer therapeutics. FEBS J. 2017, 284, 1952-1966. [CrossRef]

472. Slaby, O.; Laga, R.; Sedlacek, O. Therapeutic targeting of non-coding RNAs in cancer. Biochem. J. 2017, 474, 4219-4251. [CrossRef]

473. Bhardwaj, A.; Srivastava, S.K.; Khan, M.A.; Prajapati, V.K.; Singh, S.; Carter, J.E.; Singh, A.P. Racial disparities in prostate cancer: A molecular perspective. Front. Biosci. (Landmark Ed.) 2017, 22, 772-782. [CrossRef]

474. Krishnan, A.R.; Zheng, H.; Kwok, J.G.; Qu, Y.; Zou, A.E.; Korrapati, A.; Li, P.X.; Califano, J.A.; Hovell, M.F.; Wang-Rodriguez, J.; et al. A comprehensive study of smoking-specific microRNA alterations in head and neck squamous cell carcinoma. Oral Oncol. 2017, 72, 56-64. [CrossRef]

475. Hasakova, K.; Bezakova, J.; Vician, M.; Reis, R.; Zeman, M.; Herichova, I. Gender-dependent expression of leading and passenger strand of miR-21 and miR-16 in human colorectal cancer and adjacent colonic tissues. Physiol. Res. 2017, 66, S575-S582.

476. Sazanov, A.A.; Kiselyova, E.V.; Zakharenko, A.A.; Romanov, M.N.; Zaraysky, M.I. Plasma and saliva miR-21 expression in colorectal cancer patients. J. Appl. Genet. 2017, 58, 231-237. [CrossRef] 